NBER WORKING PAPER SERIES

\title{
THE CROSS BORDER MERGERS AND ACQUISITIONS WAVE OF THE LATE 1990s
}

\author{
Simon J. Evenett \\ Working Paper 9655 \\ http://www.nber.org/papers/w9655
NATIONAL BUREAU OF ECONOMIC RESEARCH 1050 Massachusetts Avenue
Cambridge, MA 02138
April 2003

I am grateful to Benno Ferrarini for his tenacious efforts to obtain data for this paper. Thanks also to seminar participants at INSEAD for some tough questions and constructive suggestions. Joshua Aizenman, Robert Baldwin, Jean Dermine, Rod Falvey, Rachel McCulloch, Matt Slaughter, Daniel Traca, Tony Venables, Xavier Vives and Alan Winters provided many much appreciated pointers and suggestions. This paper was presented at both meetings of the International Seminar on International Trade, jointly organized by the Centre for Economic Policy Research and the National Bureau of Economic Research. This chapter will be published in a book titled Challenges to Globalization and edited by Robert E. Baldwin and L. Alan Winters, sometime later in 2003. The views expressed herein are those of the authors and not necessarily those of the National Bureau of Economic Research.

(C)2003 by Simon J. Evenett. All rights reserved. Short sections of text not to exceed two paragraphs, may be quoted without explicit permission provided that full credit including Cnotice, is given to the source. 
The Cross Border Mergers and Acquisitions Wave of the Late 1990s

Simon J. Evenett

NBER Working Paper No. 9655

April 2003

JEL No. F2, L4

\begin{abstract}
To establish a benchmark, the cross border mergers and acquisitions wave of the late 1990s is compared to its predecessor in the late 1980s. It is found to be at least five times larger (in real terms), to involve firms from more OECD nations, and to include many more service sector transactions. However, in comparison to the size of national stock market capitalizations, foreign mergers with and acquisitions of domestic firms during this latest wave were small, especially in the Group of Seven leading industrial economies. The effect of cross border mergers and acquisitions on performance in one important service sector, banking, is also examined. Specifically, the relative importance of cross border mergers and acquisitions, domestic mergers and acquisitions, domestic entry and exit, and strategic alliances and joint ventures for interest rate spreads was estimated for 13 industrial nations. The principal findings suggest that the effects of these firm-driven changes in banking market structure differ markedly between EU member states and non-EU industrialized economies. This highlights the importance of differentiating between types of cross border inter-firm agreements and the pitfalls of generalising about the effects of the latest wave of cross border mergers and acquisitions - as many of the harshest critics of globalization do.
\end{abstract}

\author{
Simon J. Evenett \\ World Trade Institute \\ University of Bern and CEPR \\ Hallerstrasse 6 \\ Bern \\ Switzerland \\ simon.evenett@worldtradeinstitute.ch
}




\section{Introduction}

As nations' markets continue to become more closely integrated through the process commonly referred to as globalization, a concern has arisen both popularly and among policy makers about the consequences for the degree of competition between firms. Critics of globalization often charge that it extends the reach of abusive oligopolies and monopolies ${ }^{1}$, and policy makers in developing countries worry whether increased openness to trade and foreign direct investment flows makes then more vulnerable to "exploitation" by multinational firms. ${ }^{2}$ Such

${ }^{1}$ See, for example, the following remarks by Mr. Martin Khor, Director of the Third World Network to the opening session of the UN's Millennium Forum on 22 May 2000:

"Our age is also defined by the process of globalisation. There are different approaches to this phenomenon. Some say it is inevitable and basically good, you just have to adjust to it and learn to reap the benefits. Others worry about the costs and advocate some safety nets to catch the losers as they fall. In truth, the essence of globalisation is the push by big companies and financial institutions to have more power, to grow bigger through taking over others, and make more profits. They have lobbied their governments, of the rich countries, to break down the national barriers that prevent them from totally free access to markets across the world, especially in the developing countries."

The text of this speech can be downloaded from http://www.twnside.org.sg/title/mk7.htm.

${ }^{2}$ See, for example, the following statement in a November 1998 submission by the Government of India to the WTO's Working Group on the Interaction Between Trade and Competition Policy:

"In contributions of intergovernmental organizations, a dominant theme along with the issue of mergers and acquisitions is the issue of contestability of markets. Although not clearly defined, an impression is created that every aspect of domestic government policy, economic and social - would, in one way or the other, affect fair trade and the contestability of markets. In a more concrete sense this debate on contestability of markets has been witnessed during the so-called Structural Impediments Initiative in the US-Japan context. With developing countries, the dangers of the doctrine of contestability of markets eroding their ability to take domestic social and economic action are even greater. Moreover, in the name of contestability, an increase in market access for MNCs may be sought by suggesting that all sectors of WTO, in one way or another, be put to the test of contestability. This may have implications for services, intellectual property rights, subsidies and a host of other areas, not to mention investment. It will, therefore, be necessary to define it clearly and narrowly in relation to specific issues and disciplines that we wish to address in the WTO regime. Some issues to be addressed would be market allocation, refusal to deal (boycott), price fixing, collusive dealing, and differential pricing (all of which are vertical RBPs). All of these practices distort or restrict trade and affect the international contestability of markets. This action is particularly called for as developing country markets and their commercial entities are more vulnerable to the effects of such RBPs and at their receiving end. Experiences with RBPs encountered by developing country firms in developed country markets illustrate how RBPs by the large MNCs put these firms at a competitive disadvantage. Instances of other so-called privately led restrictive business practices such as debarring Indian participation in the Dutch Flower Auction or the Basle Jewellery and Watch Fair are also relevant."

$\mathrm{MNC}$ and RBP are abbreviations for multinational corporations and restrictive business practices, respectively. This text was taken from paragraph two of WTO document number WT/WGTCP/W/111, which can be downloaded from the WTO's website (www.wto.org). See also the examples described in Mehta and Nanda (2003). 
policymakers wonder if they have- or can ever have - the national tools to tackle private anticompetitive practices. ${ }^{3}$

There is also a vibrant debate about the potential for international accords on competition law and enforcement. Policy makers worldwide are engaged in discussions about the desirability and viability of a multilateral framework on competition policy under the auspices of the World Trade Organization (WTO). ${ }^{4}$ Proponents of such a framework have called for disciplines on socalled hard core cartels, so-called core principles for competition law and enforcement, modalities for voluntary cooperation, and for the progressive strengthening of competition policy-related institutions in developing countries. ${ }^{5}$ Others argue for the development of best practices for competition law and enforcement in fora such as the International Competition Network and the Organisation for Economic Cooperation and Development. ${ }^{6}$ And, others have called on industrialized economies to tackle the alleged anti-competitive practices of their multinational firms in developing economies. This proposal would involve antitrust enforcement officials expanding their traditional concern about harm done within their jurisdiction to harm done abroad. It is argued that such an approach would reduce the outlays on antitrust enforcement by developing economies. ${ }^{7}$

In principle, integrating national markets both reduces and enhances the opportunities and viability of anti-competitive conduct by private firms. On the one hand, as countries open up their domestic markets to foreign competition by reducing their tariffs and other trade-distorting policies,

\footnotetext{
${ }^{3}$ A recent study of the experience in implementing competition law in seven developing countries offered the following remark about the ability of these countries' antitrust enforcers to address international mergers and acquisitions and anti-competitive practices:

"Whether countries have special provisions for extra-territorial jurisdiction or apply the 'effects' doctrine is not important when they have no means to enforce their decisions. Often the companies involved are beyond the reach of the competition agencies, which also causes problems in obtaining the information necessary to make a decision." (CUTS 2003, page 75).

${ }^{4}$ For an excellent overview of the discussions within the WTO's Working Group on the Interaction Between Trade and Competition Policy, see that Working Group's Annual Report for 2002 (WTO, 2002).

${ }^{5}$ The European Commission is one of the leading proponents of such a framework. It's proposals can be downloaded from the WTO's website. The Commission has further clarified its proposals in discussions at the WTO's Working Group, see WTO (2002). The doubts of critics and sceptics are also reported in WTO (2002). For an analysis of the implications of such a framework for the design and implementation of national competition law, for industrial policy and development policy options, and for the resource costs faced by developing countries, see Evenett (2003a).

${ }^{6}$ For several proposals on best practices in the merger enforcement area, see the contributions to Rowley (2002). More generally, discussions on best practices in competition law and enforcement are undertaken often in the OECD's Competition Committee. Many of the relevant documents can be found at http://www.oecd.org/EN/document/0,EN-document-768-nodirectorate-no-22-20233-768,00.html. A number of interesting and informative documents on best practices in merger review can be found on the website of the mergers working group of the International Competition network, http://www.internationalcompetitionnetwork.org/wg1.html.

${ }^{7}$ See Hoekman and Mavroidis (2002).
} 
domestic incumbents that have been protected from international competition by these trade barriers are now more likely to be forced to abandon their price-raising and anti-competitive practices. ${ }^{8}$ Moreover, the increased opportunities for international mergers and acquisitions can bring cost-reducing efficiencies that may be passed on to customers, be they private consumers, firms, or governments. On the other hand, globalization also presents new opportunities for firms to form hard core cartels ${ }^{9}$ with international reach and other various anti-competitive arrangements. Thus, whether globalization promotes or reduces competitive behavior on balance is largely an empirical rather than theoretical issue.

In this chapter, I first describe in considerable detail the nature of the wave of cross border mergers and acquisitions (M\&A) that occurred during the period of rapid globalization in the 1990s and then focus on one particular service sector, namely banking, to investigate if there is evidence that cross-border M\&A in this industry resulted in greater spreads between the interest rates paid by borrowers and those rates paid to depositors. Of course, there are limits to what can be learned from a single sector study, but hopefully this analysis will contribute to the factual record, to the literature on consolidation in the banking sector, as well as shedding light on the importance of a number of factors that should be considered when coming to a view on the welfare consequences of the latest wave of cross-border mergers and acquisitions.

My analysis yields several findings. First, the recent cross border M\&A wave is in real terms at least five times larger than its predecessor in the 1980s. Even after correcting for the rising price of financial assets ${ }^{10}$, in this latest wave cross border M\&A is much much larger. Second, although the latest wave involved firms from more countries than in the 1980s, the overwhelming bulk of such M\&A still took place among the members of the OECD. Third, despite its greater scale in real terms, the latest wave of cross border M\&A represents purchases of only a small fraction of the publicly-traded corporate assets in industrial economies, especially in the Group of Seven leading industrial economies. Foreigners are, therefore, not taking over large tranches of national economies through cross border M\&A. Fourth, the preponderance of cross border M\&A in the late 1990s were in service sectors, many of which are pretty much immune to import competition.

\footnotetext{
${ }^{8}$ For a classic statement of this perspective, see Bhagwati (1968).

${ }^{9}$ For evidence on private international cartels see Evenett (2003a), Levenstein and Suslow (2001), and OECD (2003).

${ }^{10}$ As proxied for by national stock market indices, see below.
} 
Fifth, in one important service sector-banking - estimating the effects of cross border mergers and acquisitions requires paying careful attention to sample composition. Furthermore, controlling for changes in regulatory regimes and other changes in market structure in banking are important. Of the thirteen OECD nations' banking sectors considered here, eight are members of the European Union. The determinants of the latters' banking spreads during the 1990s is found to be much different from those in non-EU economies. In the banking sectors of EU member states, domestic M\&A and strategic alliances are found to have no net effect on bank spreads. Cross border mergers and acquisitions are found to depress spreads, suggesting that substantial efficiencies resulted from such consolidation. In contrast, the evidence suggests that cross border strategic alliances result in higher spreads - a finding that is consistent with the view that some such alliances have been formed to forestall further market integration and to preserve the independence of banks in Europe.

The parameters in the non-EU sample are less precisely estimated, reflecting in large part a smaller number of observations. Only cross border strategic alliances are found to influence bank spreads in a statistically significant manner - in this case depressing them (which is the opposite of my finding in the EU sample.) Nevertheless, taken together this chapter's results for the banking section imply that it is hazardous to make sweeping generalizations about the net effect of cross border transactions, especially as the latter can have both pro-competitive and anti-competitive effects.

Sixth, the estimated parameters are used to forecast the net effect of all of these domestic and cross border inter-firm agreements on bank spreads in each of the thirteen countries considered in my EU and non-EU samples. In each EU member state, the combined effect of cross border inter-firm agreements on interest rate spreads is an order of magnitude larger than for domestic inter-firm agreements. Moreover, the overall beneficial effect of cross-border M\&A in banking ${ }^{11}$ in the EU has, in all of the eight EU members considered here, been completed reversed by the harm done by cross-border strategic alliances. This implies that the combined effect of the latter may not be as benign or as inconsequential as they first appear. ${ }^{12}$ Moreover, as the number of cross-border strategic alliances in banking in the EU appears to have increased considerably after the crossborder M\&A spurt began, my findings are consistent with the explanation that banks eventually

${ }^{11}$ This is not to say that every cross-border merger or acquisition in the banking sector generates enough efficiencies that bank customers benefit.

${ }^{12}$ This is not say that every cross-border strategic alliance detrimentally affects the welfare of bank customers. 
took rearguard actions to increase their market power after the spread-reducing effects of efficiency-enhancing cross-border mergers and acquisitions were felt. If this view is correct, then regulators in the banking sector and competition policy officials should not focus solely on the potential consequences of mergers and acquisitions and should keep a beady eye on perhaps more innocently-looking public announcements of strategic alliances.

This paper is organised as follows. The next section describes the recent wave of cross border mergers and acquisitions. The third section focuses on the consolidation in the banking system in 13 industrialized economies, establishing the factual record first and then conducting econometric analyses. The final section contains some concluding remarks.

\section{The cross border mergers and acquisitions wave of the late 1990s}

\section{Preliminaries}

Before turning to the factual record it may be helpful to clarify the terms used in this chapter. An important distinction is between foreign direct investment (FDI) and cross border mergers and acquisitions. As the principal source of data on cross border M\&A used here is the United Nations Conference on Trade and Development's (UNCTAD's) annual World Investment Report, I reproduce below UNCTAD's description of the difference between cross border M\&A and FDI:

"A firm can undertake FDI in a host country in either one of two ways: greenfield investment in a new facility or acquiring or merging with an existing local firm. The local firm may be privately or state owned: privatisations involving foreign investors count as cross border M\&As, which entails a change in the control of the merged or acquired firm. In a cross border merger, the assets and operation of the two firms belonging to two different countries are combined to establish a new legal entity. In a cross border acquisition, the control of assets and operations is transferred from a local to a foreign company, the former becoming an affiliate of the latter." (UNCTAD, 2000, page 99)

Although this quotation clarifies the distinction between investments in new productive entities and investments in existing entities it would be incorrect to infer that, in practice, the reported value of cross border M\&A transactions is always less than the reported amount of foreign direct investment. In fact, measured cross border M\&A received by a nation is taken to be the sum of (i) foreign investments in existing domestic firms which result in equity stakes greater than ten percent, (ii) foreign investments in existing domestic firms which result in equity stakes less than ten percent, and (iii) foreign investments in existing domestic firms that are paid for using capital or 
funds raised in the nation of the acquiring firm. In contrast, the reported amount of FDI received by a nation includes (i), (iii), plus the value of overseas investments paid for by reinvested earnings of foreign firms already resident in the nation. Consequently, as UNCTAD (1996) notes:

"It is, therefore, possible to witness a large increase in M\&As that is not fully reflected in FDI flows...[and]... movements in FDI flows can take place independently of movements in M\&A. In practice, however, there is a close relationship between movements in M\&As and FDI flows." (Box I.1, UNCTAD, 1996).

To underscore the differences between measured cross border M\&A and FDI into industrial countries, Table 1 reports the ratio of the former to the latter in 13 OECD nations during 19951999. In some countries (Australia, France, Spain, and Japan) the ratio is far from one - suggesting that recorded cross border M\&A and FDI differ markedly.

In collecting data on cross border M\&A UNCTAD attempts, whenever possible, to establish the location of the "ultimate" corporate owner of a given firm, not an "intermediate" owner that too may be owned by another firm. This is done by examining newspaper announcements of actual and proposed transactions complemented by the use of databases that identify which firms own other firms. By locating the headquarters of an ultimate corporate owner, one can assign a "nationality" to the owner. This, of course, sidesteps the fact that a publicly traded company may have shareholders/stockholders who are resident in more than one country-a wrinkle that is easy (and important) to state but is difficult to address adequately.

\section{Factual record ${ }^{13}$}

Turning now to the data, using 1987 constant dollars, Table 2 and Figure 1 report the extent of cross border mergers and acquisitions activity from 1987 to 2000, the peak year of the latest boom. (In 2001, reports suggest that cross border M\&A fell 40 percent in nominal terms.) As Figure 1 makes clear, the recent wave of cross border M\&A accelerated after 1996 and reached a peak of $\$ 828$ billion in 2000 (which is equivalent to $\$ 1.1$ trillion dollars in year 2000 dollars). The previous wave of cross border M\&A, which took place from 1987 to 1990, reached a peak of $\$ 135$ billion in 1990-less than a fifth of the peak in the latest wave. Furthermore, developing economies played next to no role in the 1980 s wave and a modest in the most recent wave. ${ }^{14}$ Perhaps for this

${ }^{13}$ For two descriptions of the factual record that include more discussion than is presented here of mergers and acquisitions in selected sectors, see Kang and Johansson (2000) and OECD (2001). For a recent account and analysis of foreign mergers and acquisitions in the United States, see Feliciano and Lipsey (2002).

${ }^{14}$ Having said that, see Mody and Negishi (2000) for an account of the growing role of cross border M\&A in overseas investments in the East Asia in the late 1990s. 
reason, it might be more accurate to call the latest wave an "international" wave rather than a "global" wave of cross border M\&A.

For further perspective on the growth of cross border M\&A in the 1990s, see Figure 2. This shows that the real growth of cross border M\&A dwarfs that of world GDP and of world merchandise trade, the latter of which almost doubled in real terms in the 1990s. In Figure 2 I deflated current values of total cross border M\&A by the same GDP deflator that I used to compute real World GDP — a procedure which can be objected to on the grounds that stock markets soared in the 1990s, raising the possibility that the price of financial capital has grown more quickly than the GDP deflator. To examine this matter further I deflated country-by-country values of nominal inward cross border M\&A by the changes in the value of each country's major stock market index ${ }^{15}$, and normalised the amount of cross border M\&A received in 1990 at 100. (The year 1990 was the peak of the wave of cross border M\&A that started in the late 1980s.) Figures 3a and 3b report this new calculation of the real value of cross border M\&A received by the ten industrialized economies throughout the 1990s. In all but two economies, real inward M\&A is much lower in 1990 than in 2000, confirming that for the major markets in the world economy the latest cross border M\&A wave was on a much larger scale than its predecessor in the 1980s.

Having said that, the growth of cross border M\&A is from a relatively small base and when the level of cross border M\&A that a nation received in the late 1990s is compared to its stock market's capitalization, the amount of assets acquired by foreign firms tends to be quite small (see Table 3). Only the smaller - and relatively more open - industrial economies saw the total value of foreign mergers and acquisitions exceed five percent of their total stock market capitalizations. For the Group of Seven leading industrial economies the inflows of cross border M\&A are even smaller relative to the size of their stock markets. The image of aggressive foreign executives snapping up large shares of productive domestic assets conjured up during the contentious merger of Vodafone and Mannesmann AG in 2000, for example, finds little support in the data.

Figures 4 and 5 provide further indications of the broader participation in the latest wave of cross border M\&A, compared to its predecessor in the 1980s. The latter was essentially an American and British affair, with some French firms making acquisitions towards the end of the boom (principally in 1990). In contrast, the current wave involved considerable transactions by

\footnotetext{
${ }^{15}$ For nine of the ten industrialized economies choosing the major stock market index was straightforward. For the United States, however, one could choose either the S\&P 500 index or the Dow Jones Industrial Index. I chose the latter index, but note that both indicies rose by similar percentages throughout the 1990s.
} 
German, French, Spanish, and Nordic firms - joining the long standing Anglo-American interest in cross border M\&A. Figure 5 compares the cumulative distribution of cross border M\&A across OECD nations in both waves, confirming the less skewed nature of the latest wave.

Another critical feature of the latest cross border M\&A wave is the important role played by so-called mega deals, those transactions whose value exceeded one billion U.S. dollars. The number of such deals nearly quadrupled from 1996 to 2000 (see Figure 6); and the (constant dollar) value of such transactions more than quadrupled (see Figure 7). In Appendix Table One, I have listed the mega deals that were announced in 2000. It is evident that the majority of such deals involved the service sector, notably the financial and telecommunications sectors. Few manufacturing firms can be found on this list, a point I shall return to below.

An examination of the sectoral breakdown of cross border M\&A during the 1980s and 1990s waves is revealing too (see Table 4 and Figures $8 \mathrm{a}$ and 8b). One striking finding is the relatively smaller importance of manufacturing cross border M\&A in the late 1990s, accounting for only 35.1 percent of the total value of such transactions. In the previous wave, such transactions accounted for 62.2 percent of the total. What is more, just three service sectors (transport, storage, and communications; finance; and business services) account for just under a half of total cross border M\&A in the late 1990s.

\section{Policy regimes facing cross border mergers and acquisitions}

Much has been made in the literature and in the reports of international organizations ${ }^{16}$ of the falling barriers to greenfield FDI during the 1990s. UNCTAD goes so far as to tally up, on an annual basis, the number of economies that have relaxed or tightened their FDI regimes. ${ }^{17}$ However, in industralized economies (and in some developing economies too) cross border mergers and acquisitions are typically influenced by two different policy regimes: merger review policies (which are described in some detail below) and sectoral regulations. The latter can involve reviews of M\&A deals (both domestic and cross border) that occur within a given sector. Regulators in financial services, banking, telecommunications, and air transportation have been active in the 1990s reviewing proposals to merge or acquire firms. What is more, some jurisdictions allow for M\&As in some sectors to be reviewed both by the relevant sectoral regulator and by the national

\footnotetext{
${ }^{16}$ See, for example, World Bank (2000) and the annual World Investment Reports published by UNCTAD.

${ }^{17}$ See UNCTAD's annual World Investment Reports for details.
} 
competition enforcement agency. ${ }^{18}$ This raises the question of the extent to which observed levels of cross border M\&A are affected by the potential for multiple official reviews within the same jurisdiction.

In contrast to policies towards greenfield FDI it is quite possible that, as a general proposition, policies towards M\&As have become more stringent throughout the 1990s. For starters, the number of jurisdictions with merger review regimes rose sharply in the 1990s (see Figure 9). ${ }^{19}$ According to White \& Case (2001), a publication of an international law firm that conducts an annual survey of merger enforcement around the world, sixty five economies had merger review laws in 2000 (plus the European Commission's supranational merger enforcement regime.) Thirty of these merger review laws have been enacted since 1990. It is also noteworthy that merger review laws are a relatively new phenomenon in some industrial economies - in other words, the spread in the last twenty years is not just a phenomenon found in developing countries. For instance, the European Commission's Merger Regulation only came into force in 1990, Italy's merger review regime was enacted in 1990, Denmark's and the Netherlands' in 1997, and France's antitrust authority only celebrated its fifteenth birthday in 2002. Finally these remarks suggest that, when studying cross border flows associated with corporate investments abroad, it is important to locate which policy regime or regimes has the greatest bearing on the flows being examined. In many cases, measures of (or proxies for) the strength of the policy regime towards greenfield investments may provide a misleading guide to the strength of the merger review regime or of the sectoral regulatory regime.

\section{Commentary and related literature}

This change in sectoral composition reflects a number of factors. First, lower trade barriers and more intense competition in world markets for manufactures are likely to reduce the incentive to engage in cross border M\&A so as to accumulate market power or to jump tariffs. Indeed, any

\footnotetext{
${ }^{18}$ For examples, see the case studies in Evenett, Lehmann, and Steil (2000).

${ }^{19}$ Figure 9 reports not only the total number of merger review laws enacted since 1970 but also the total number of such laws requiring notification of proposed mergers and acquisitions before deals are completed. Among legal practitioners and scholars the latter type of merger review regime are, by and large, regarded as the most stringent form of merger review law (see ICPAC, 2000, for a statement of what might be called conventional legal wisdom in this regard. See, also, Evenett (2002) which confirms that of the three main types of merger review laws, those requiring mandatory pre-notification curtail cross border M\&A the most.) In the light of these remarks, it is noteworthy that a growing proportion of the merger review laws enacted in the 1980s and 1990s are of the mandatory pre-notification type (see Figure 9). This is further evidence in favor of the proposition that worldwide the policy regime towards M\&A has become stricter over time. (It may well be the case that the policy regimes towards M\&A in individual countries have been relaxed throughout the 1990s.)
} 
increments in market power are likely to result in greater supplies from competitors located at home and abroad. This suggests the following hypothesis: in those industries where international competition is fiercest, $\mathrm{M} \& \mathrm{~A}$ is more likely to be motivated by cost-cutting rationales. Second, the increase in service sector M\&A reflects deregulation, privatization, and the relaxation on restrictions on foreign ownership in many industrial economies. Although such reforms began in the 1980s in a few industrial economies (notably Britain, New Zealand, and the United States), in many other countries they were not implemented on a wider scale until the 1990s. This is not to say that the all the major service sectors are deregulated, but rather that the pace of deregulation picked up in the 1990s and that this presented opportunities for foreign investors. In many continental European economies the pace gathered in response to the Single Market Programme and the liberalization initiatives that ensued.

Although the corporate finance literature on the causes and financial effects of mergers and acquisitions is quite voluminous, there are relatively few papers on the determinants and consequences of cross border $\mathrm{M} \& \mathrm{~A}^{20}$ and on economic analyses of the policy regimes governing such cross border transactions. ${ }^{21}$ Black $(2000 \mathrm{a}, \mathrm{b})$ describes a number of political and economic factors that, in his opinion, account for the recent surge in cross border M\&A. He points to the "breakdown of the old antitakeover coalition" (Black, 2000a, page 10). Unions have weakened and managers own more stock options, which ties their remuneration more closely to corporate performance-reducing, he claims, the incentive to defend against the takeover of a poorly performing firm. Lower inflation and a surging stock markets, it is argued, have reduced the costs of financing M\&A (although this explanation surely applies to domestic M\&A as well as to cross border M\&A.) Finally, Black notes that there is now less opposition to concentrations of wealth and that integrating national markets have encouraged firms to aspire to activities on a worldwide scale. Pryor's (2001) focus, in contrast, is on documenting the consequences for the United States of the recent boom in domestic and cross border M\&A. He argues that such transactions have increased the concentration of manufacturing industries in the 1990s and, in his opinion, can be expected to continue to do so in the future.

An econometric approach was taken in Evenett (2002, 2003b). Employing a gravity equation approach in both studies, Evenett estimated the contribution of different factors to the

\footnotetext{
${ }^{20}$ This paucity of studies on cross border M\&A is to be contrasted with the voluminous literature on FDI, which the earlier discussion suggests is a distinct but related phenomenon.

${ }^{21}$ There are a number of legal analyses of the policy regimes influencing cross-border mergers and acquisitions.
} 
value of American outward M\&A that 49 foreign economies received in 1999, including the effect of national merger review regimes. In both studies, several nation-specific factors are found to be important determinants of cross border M\&A including the recipient nation's gross domestic product, the distance from the United States, the recipient nation's corporate tax rate and average tariff rate, and whether or not the recipient nation was once a British colony (and is, therefore, more likely to use English as the language of business and to have a common law system, which the United States has too.) Evenett (2003b) also found that the presence of merger review laws tend to cut in half the amount of American M\&A received. This constitutes a substantial barrier to the international trade in corporate assets, and is especially important given the 1990s saw more and more developing economies adopt merger review laws - in particular those developing nations that hoped to join the European Union at some point in the future.

Evenett (2002) also found that the combined effect of merger enforcement by national authorities in the European Union and by the European Commission curtailed American overseas M\&A by the same percentage ${ }^{22}$ as comparable non-European merger enforcement agencies. This finding may be of interest in the light of the sharp transatlantic dispute over the proposed merger between General Electric and Honeywell in 2001, where accusations were made that the European merger authorities discriminated against proposed American mergers. ${ }^{23}$

The economic impact of cross border M\&A depends on a number of considerations which make it unlikely that sweeping claims can be made with any confidence about the desirability (or otherwise) of such international trade in corporate assets. By reducing the number of firms that supply a market, cross border M\&As may enhance the market power of the surviving firms. However, such changes in ownership may also result in the combined entity attaining greater economies of scale and scope which, in turn, may benefit consumers in the form of lower prices, a wider range of services offered, or higher quality goods and services. One often-mentioned mechanism is that foreign firms transfer so-called cutting edge technologies and better managerial practices to domestic firms that they have merged with or acquired-suggesting that the beneficial effects of mergers and acquisitions could be greater in the cross border case, compared to a

\footnotetext{
${ }^{22}$ In this case, fifty percent.

${ }^{23}$ Note that this finding in Evenett (2002) does not speak to the issue as to whether EC merger enforcement procedures tends to discriminate more against transactions involving American firms than transactions involving non-American firms.
} 
domestic transaction. However, there are no guarantees that these pro-competitive aspects of cross border M\&As will necessarily completely offset any anticompetitive effects of such transactions. ${ }^{24}$

The strength of each of these considerations is likely to vary from industry to industry. For example, as noted above, those sectors that face aggressive import competition are ceterius paribus less likely to see cross border M\&A result in higher prices. Sectors, such as banking, where firms increasingly offer a wide range of financial products to customers, are especially likely to gain from merging or acquiring a financial institution that sells complementary products. Another sector, telecommunications, has seen rapid technological progress in the 1990s and cross border M\&As are often mentioned as one of the conduits by which such innovations are diffused across national borders-along with the managerial practices that are needed to make good the profitable opportunities created by these technological improvements. In terms of general findings, therefore, a sector-by-sector evaluation of the effects of cross border M\&A is probably the most one can ever realistically expect, and in the next section I attempt such an evaluation of the recent consolidation in the banking system in 13 OECD nations.

A final point, whose implications tend to be thought through in many other international economic policy matters but which has, until now, received less attention in discussions of international antitrust matters, is that cross border M\&A may well have economic effects that spill across national borders and that national antitrust or competition authorities tend to focus only on the effects within their own jurisdictions. Therefore, no government entity exists to aggregate the effects of a proposed transaction across all the affected national markets. ${ }^{25}$ This may lead to situations where a transaction is vetoed in some jurisdictions (where the economic consequences are thought to be adverse) even though there is a positive effect on net across all the affected markets.

\footnotetext{
${ }^{24}$ One important - and contentious - issue is to what extent ownership changes are needed to secure the procompetitive benefits of mergers and acquisitions. Direct contracting and collaborative (or so-called strategic) alliances may provide the means by which a domestic firm can market a foreign firm's range of products, or by which a domestic firm can expand its output (potentially reaping economies of scale) by producing goods under contract for a foreign firm. This raises the possibility that all the resource allocation benefits of cross border M\&As can be obtained by signing inter-firm agreements which do not involve reducing the number of suppliers. However, the point need not to be taken too far as transactions costs arguments often point to the need for cross-holding of equity to attenuate incentive problems. Furthermore members of an inter-firm alliance or contracting, that starts off with pro-competitive effects, may well soon figure out how to turn their collaboration to price-raising ends.

${ }^{25}$ Within the European Union, for example, the European Commission could play such an aggregating role. This is not to say that it does play such a role!
} 
Essentially, the absence of any compensation mechanism between states implies that multiple national vetoes can lead to suboptimal enforcement of cross border mergers and acquisitions. In recent years, a leading antitrust American official has given attention to the issue of multiple national vetoes (see Muris 2001), but the importance of the lack of any compensation mechanism for resource misallocation has yet to receive much attention in legal and economic discourse on merger reviews. Indeed, the absence of such a mechanism is one of the key characteristics that differentiates the international effects of the national antitrust enforcement from trade policy negotiations. In the latter, it has long been understood that any losses to a nation in one sector are compensated for by concessions in other sectors by trading partners. Without suggesting that cross-sectoral tradeoffs are the optimal means to conduct multi-jurisdictional merger reviews, there is probably some value in thinking through the implications of compensation mechanisms across merger cases that prevent a proposed merger or acquisition whose total effects worldwide are welfare improving from being blocked by a single jurisdiction in which it is thought that the transaction's effects are adverse. ${ }^{26}$

\section{Consolidation of the banking systems in thirteen industrial nations}

I now turn to an econometric evaluation of the effects of cross border mergers and acquisitions in the banking systems of 13 industrial economies. When conducting such evaluations the importance of controlling for changes in regulatory structure, for sample composition, and for other determinants of market structure in the banking sector-such as domestic M\&As, domestic entry and exit of banking, and the formation of joint ventures and strategic alliances between banks - will become evident. But, first, I review the facts on banking consolidation as presented in Tables 5 and 6, which were assembled from a detailed report on bank consolidation during the 1990s that was published by the Bank of International Settlements (BIS, 2001). This report referred to consolidation in thirteen OECD nations, namely, Australia, Belgium, Canada, France, Germany, Italy, Japan, the Netherlands, Spain, Sweden, Switzerland, the United Kingdom, and the United States.

During the 1990s these thirteen OECD economies experienced 3563 mergers and acquisitions that involved a domestic bank and another domestic bank. This domestic consolidation dwarfed in number (and in value) the amount of cross border M\&A in banks (which totalled 338 transactions worth in current dollars approximately $\$ 73$ billion (see Table 5). What is more, many

\footnotetext{
${ }^{26}$ For more discussion on the potential for resource misallocation in multi-jurisdictional merger review see Evenett (2003c) and Neven and Roller (2001).
} 
banks engaged in joint ventures and in strategic alliances during this period, in particular in the United States, Japan, and Canada (Table 6). In short, cross border M\&A was not the only factor influencing the concentration and the market structure of these nations' banking systems.

Research on banking mergers points to a number of rationales for this observed consolidation. Carow and Kane (2001), for example, point to the following potential benefits of mergers and acquisitions: cost-based economies of scale, brand-based economies of scale, revenuebased economies of scale, safety net-based economies of scale, revenue-based economies of scope, X-inefficiency, market power, and managerial agency costs (Table 1, Carow and Kane 2001). Dermine (1999), whose analysis Carow and Kane developed, noted that the following attractions to bank M\&As has been asserted in the literature: that size can bring "defense based economies of scale" (that is "achieving size...that acts as a defensive measure against takeovers" (Dermine, 1999, page 16), and the long standing "quiet life" hypothesis. Moreover, to the extent that strategic alliances between banks enable them to enhance the range of products that they supply (and in so doing market their partners' products too), and to the extent that alliance partners can share costs in supplying products (perhaps by reducing any duplication in distribution networks), then such alliances can generate cost efficiencies too.

My interest here is in the market power and efficiency-related aspects of bank mergers and acquisitions. In particular, I focus on the effects on one important observable variable, the interest rate spread; that is, the difference between the interest rates paid by borrowers and those paid to depositors. Part of that spread will be determined by the costs associated with collecting deposits, but more importantly by the costs associated with locating and screening potential borrowers. Another determinant of the spread is market power, and this depends on the number of options available to both depositors and the borrowers. If potential depositors have few choices as to where to place their savings, then incumbent banks can offer lower deposit rates which ceterius paribus raises spreads. Likewise, if potential borrowers have few alternatives to seeking funds from the incumbent banks, then the interest rate paid by the former will be higher, raising spreads.

In the absence of efficiencies, bank M\&As can be expected to raise spreads as the number of banking options facing depositors and borrowers declines. Only if there is sufficient rivalry between banks after a merger takes place will any efficiencies created by the merger be passed onto consumers in the form of lower spreads. ${ }^{27}$ It is an empirical question whether market power or

\footnotetext{
${ }^{27}$ For a more sophisticated overview of the causes and consequences of market power in banking, see Vives (2001), section III.
} 
efficiencies dominates. To date, the empirical literature on bank mergers is mixed on the relative importance of these two factors (see the discussions in Berger, DeYoung, Genay, and Udell, 2000, Calomiris and Karceski, 2000, and Vives, 2001.)

To estimate the effects on interest rate spreads of the changes in the national banking sectors documented in Tables 5 and 6, I assembled from BIS (2001) and the World Bank's World Development Indicators (WDI) an unbalanced panel comprising the thirteen nations in the BIS study. The unbalanced nature of the panel resulted from the fact that in some countries the five firm concentration ratios in the banking sectors were not reported in the BIS study for every year from 1990 to 1999 . The BIS study provided annual data on the number of banks in each country, the number and types of strategic alliances, and the number and types of M\&A.

The dependent variable for this study - the interest rate spread - was taken from the WDI CD-ROM. This source defines the interest spread as

"the interest rate charged by banks on loans to prime customers minus the interest paid to by commercial or similar banks for demand, time, or savings deposits." (WDI CD-ROM) ${ }^{28}$

The mean value of this spread for each economy is reported in Table 7, which sorts the economies according to the annual average number of cross border mergers and acquisitions. The highest mean spread (6.35 percent) is in Germany and the lowest spread is in Canada (1.34 percent). Data on three macroeconomic series - gross domestic products, GDP price deflators, and stock market capitalization - used to form control variables (which are described later) was also assembled from the WDI. Both GDP growth and the inflation rate are intended to proxy for the stage of the business cycle, whereas the size a nation's stock market is supposed to proxy for the extent to which financial markets can act as an alternative source of finance for borrowers and as an alternative destination for personal savings.

The objective of the econometric strategy is to discern-after stripping out the variation created by the business cycle and any competition for funds created by the stock market and by the impact of regulatory changes - whether interest rate spreads in the 1990s have been influenced by the formation of the numerous strategic alliances and the consummation of bank M\&As. Of especial interest is whether cross border M\&A and cross border strategic alliances have different

\footnotetext{
${ }^{28}$ Some seminar participants have questioned the accuracy of the WDI data on bank spreads. I checked other available series on bank spreads - specifically, those from the International Monetary Fund and the comprehensive DATASTREAM financial database - and found that these confirmed the data on spreads reported in the WDI.
} 
effects from their domestic counterparts. So that my econometric estimates are not determined entirely by the boom years of cross border M\&A (1997-2000), the dataset used covers as much of the 1990s as the data sources employed here would allow.

I proceed from a parsimonious specification to richer ones. The first specification purges the variation in bank spreads of variation associated with a set of macroeconomic controls and includes country-specific fixed effects. The estimation equation is as follows:

$$
\text { (1) } \ln \left(\frac{1+L_{i t}}{1+D_{i t}}\right)=a_{i}+b \ln \left(M_{i t}\right)+\varepsilon_{i t}
$$

where

$$
\ln \left(M_{i t}\right)=b_{1} \ln \left(\frac{G D P_{i t}}{G D P_{i(t-1)}}\right)+b_{2} \ln \left(\frac{P_{i t}}{P_{i(t-1)}}\right)+b_{3} \ln \left(S M_{i t}\right)+b_{4} \ln (t)+\ldots
$$

and

$$
\begin{aligned}
& i=1, \ldots, \mathrm{N}, \mathrm{N}=13 \\
& t=1990, \ldots, 1999 .
\end{aligned}
$$

$a_{i} \quad$ is a country-specific fixed effect for economy $i$.

$\mathrm{L}_{i t} \quad$ is the prime rate paid to borrowers from banks in economy i in year $\mathrm{t}$.

$\mathrm{D}_{i t} \quad$ is the interest paid to depositors in banks in economy $\mathrm{i}$ in year $\mathrm{t}$.

$\mathrm{GDP}_{i t}$ is the gross domestic product of economy $\mathrm{i}$ in year $\mathrm{t}$.

$\mathrm{P}_{i t} \quad$ is the GDP deflator in economy $\mathrm{i}$ in year $\mathrm{t}$.

$\mathrm{SM}_{i t}$ is the total stock market capitalization of economy $\mathrm{i}$ in year $\mathrm{t}$ as a percentage of GDP it.

The vector $\mathrm{M}_{\mathrm{it}}$ includes the four macroeconomic controls outlined above plus the (six) twoway interaction between these four controls. The parameter estimates, obtained by confronting specification 1 with the data from my unbalanced panel of thirteen economies, account for 6.43 percent of the within variation, see Table 8 . The estimation procedure used weighted least squares to take account of any country-specific (or group wise) heteroskedacity. ${ }^{29}$

Specifications 2 and 3 (in Table 8) include parsimonious controls for changes in market structure. Specification 2 includes the logarithm of the five firm concentration ratio as an

${ }^{29}$ Specifically, the weight applied to each country's data in a second stage regression is the estimate of the standard deviation of the residuals that were recovered from an unweighted first stage regression using ordinary least squares. 
independent variable. Specification 3 goes further and introduces as two additional distinct independent variables the logarithms of (one plus) the number of annual strategic alliances and (one plus) the number of annual M\&As consummated since 1990. Both specification yield the traditional finding that increases in the concentration ratio raises interest rate spreads. Specification 3 provides the first evidence that strategic alliances appear to raise interest rate spreads, whereas M\&As tend to have no statistically significant effect on them.

One objection to specification 3 is that the observed concentration ratio in a given year may well, in turn, be influenced by the number of strategic alliances and mergers and acquisitions that have occurred in the past or are taking place currently. Consequently, in addition to allowing for time invariant country-specific determinants of concentration, I also purged the variation of the five firm concentration ratio of the observed levels of strategic alliances and M\&As. ${ }^{30}$ This purged concentration ratio was used in specification 4 instead of the actual concentration ratio in specification 3. The upshot: precious little changes. ${ }^{31}$

Another objection to specifications 1-4 is that they do not take into account the entry and exit of domestic banks that is independent of M\&A. Specification 5 includes as an independent variable the logarithm of the number of banks in an economy. With this additional explanatory variable, the effect of the concentration ratio on interest rate spreads still has the correct sign and the parameter estimate on the strategic alliance variable remains little changed. Entry of banks is found to depress spreads, but not in a statistically insignificant manner.

As the BIS data source enables me to differentiate between domestic and cross border strategic alliances and between domestic and cross border M\&A, I entered them as separate independent variables in specification 6. Interestingly, domestic M\&A and domestic strategic alliances are found to raise spreads, with the estimated parameter on the former 50 percent larger than on the latter. In contrast, cross border M\&A does appear to reduce spreads. However, in

${ }^{30}$ Specifically, in specification 4 I regressed the concentration ratio on country-specific dummies and the logarithm of one plus the total number of strategic alliances and the total number of mergers and acquisitions. Following standard procedures, the estimate of the "purged" concentration ratio is the estimated residual of the regression described above in this footnote.

${ }^{31}$ Note that in specifications 4-7 I purged the concentration ratio of country-specific fixed effects plus each of the M\&A and strategic alliance variables included in a given specification. Moreover, in specifications 5-7 I also purged the concentration ratio of the logarithm of the number of banks. In specification 7, I also purged the concentration ration of the explanatory power of the dummies picking up changes in bank regulatory regimes. In each specification, the goal of this "purging" procedure is to identify that component of the concentration ratio that cannot be attributed to the changes in national market structures in the banking sector, to national regulatory changes, or to other national characteristics that do not vary over the years of data in the sample (1990-1999). 
specification 6 these findings do not survive the inclusion of controls for regulatory changes in the thirteen OECD nations during the 1990s. ${ }^{32}$ Specification 7 includes these controls and the parameter on the cross border M\&A variable loses its significance. Nonetheless, the estimated parameters do suggest that domestic consolidation and strategic alliances in the banking system have raised spreads-whereas their cross border counterparts do not.

The next step was to examine whether these qualitative findings held up to changes in sample composition. First, I eliminated each country one at a time from the sample and re-estimated the parameters. The new parameter estimates varied little from previously. Second, I eliminated the North American economies (Canada and the United States) from the sample-again with little effect. Third, I eliminated Japan and Australia from the sample and found not much changed. This seemingly robust set of regression findings was overturned when I split the thirteen nation sample into a sample comprising of European Union (EU) members and a sample comprising the rest. Arguably, the former's banking sectors have been affected by the implementation of two European Banking Directives (and other measures to enhance the integration of European markets). Such considerations may result in banking consolidation in Europe having different effects than in other parts of the industrialized world. Table 9 and 10, which report the parameters estimated in Table 8 for the eight nation EU sample and the five nation non-EU sample respectively, confirm that differences do exist between these samples.

In the EU sample, cross border strategic alliances are found to increase spreads. Perhaps such alliances in Europe were formed to frustrate entry and segment markets, rather than to enhance economies of scale and scope. Interestingly, where EU banks have gone beyond such alliances and have actually merged with banks located in another EU member, the evidence suggests that spreads do fall (see specification 7, Table 9). In contrast, domestic inter-bank alliances in EU member states appear to have no effects on bank spreads - suggesting that any economies reaped are probably offset by a diminution in competition.

The performance of the specifications in the non-EU sample is rather mixed. For sure, with the inclusion of the regulatory controls (in specification 7, Table 10), over half of the variation in the dependant variable is explained. However, few of the market structure variables - such as the purged concentration ratio - are found to have had a statistically significant effect on interest rate spreads. This may reflect the fact that the degrees of freedom in the sample is quite small (less than

\footnotetext{
${ }^{32}$ Appendix Table 2 lists the major banking sector-related changed identified in Annex II.3 of BIS (2001).
} 
30). Even so, outside the EU cross-border strategic alliances were found to depress interest rate spreads, suggesting that such corporate agreements generate efficiencies.

The parameter estimates from specification 7 (in both Tables 9 and 10) can be used to quantify the total effect of the observed domestic and cross border consolidation in the banking sectors that occurred in the $1990 \mathrm{~s}$, as well as the total effect of the formation of strategic alliances. Table 11 reports country-by-country the point estimates of the total effect on interest rate spreads of the domestic and cross border banking changes observed throughout the 1990s. In every non-EU country considered here, the combined effect of the domestic banking changes was to raise spreads, but this was offset by the beneficial effects created by cross border strategic alliances and M\&A. In each EU economy the net effect of domestic banking changes on spreads is almost zero and is dominated by the spread-increasing effects of cross-border strategic alliances. Indeed, had those cross border strategic alliances not occurred in the 1990s, bank spreads (as measured by the dependent variable) in each EU country considered here would have been at least two whole percentage points lower in 1999. In contrast, in the five non-EU economies cross border strategic alliances and mergers have helped reduce spreads by between 1.3 and 3 percentage points.

These findings suggest that inter-bank agreements and consolidation in the 1990s had important effects on interest rates and, therefore, on the welfare of lenders or borrowers. What is doubtful, however, is that sweeping statements about the effects of cross-border inter-bank agreements can be made with any confidence. Indeed, the emphasis in much commentary on globalization on the role of cross-border M\&A is somewhat misplaced, at least in banking, as it appears that the consequences of cross-border strategic alliances are a more important part of the story.

\section{Concluding remarks}

The cross border mergers and acquisitions wave of the 1990s was on a different scale than its predecessor in the late 1990s: it included more firms from more countries, it saw a greater number of transactions many of which were mega deals; and it was dominated by service sector transactions - in fact, three sectors (namely, transportation and communication; finance; and business services) accounted for just under half of the value of all M\&A from 1997 to 2000. An evaluation of this recent cross border mergers and acquisitions wave is, thus, in large part an evaluation of its effects on these three sectors. What is more, in each case there are good reasons for suspecting that cross border M\&A was not the only major change in their market structures in 
the 1990s. The telecommunications sector saw much deregulation and technological advances, as did business services. In banking, whose consolidation was studied in more detail in this chapter, strategic alliances and domestic M\&As were consummated in large numbers in the 1990s. Correcting for these other developments was found to be important when accurately gauging the effect of cross border mergers and acquisitions in the banking sector.

My empirical analysis of thirteen OECD economies' banking sectors points to a discernable impact of openness to foreign banking activities on bank spreads. In eight EU economies the beneficial consequences of cross border M\&As was more than offset by the deleterious impact of cross border strategic alliances. In contrast, the net effect of openness to foreign banking activities has been to benefit customers in non-European industrialized economies.

This chapter speaks to a number of themes discussed throughout this book. First, by documenting the factual record on cross-border mergers and acquisitions, a better sense of the scale of this phenomenon emerged. Facts replace assertions. For sure, cross border mergers and acquisitions in the late 1990s were greater than in the late 1980s. However, the former still only represent a small fraction of the stock market capitalizations of all but the smallest industrialized economies. Indeed, in almost every industrial country foreigners are hardly snapping up domestic assets at a rate that some might find alarming.

The second important finding of this chapter relates to the concern that changes in the global economy in recent years have sought to reinforce the market power of corporations. The sectoral study of banking presented here points to the importance of correctly identifying all of the changes in a given sector's structure and its regulations before drawing any inferences about the effects of consolidation on customers. In the banking sector in the EU the evidence suggests that cross-border M\&As has actually benefited bank customers rather than harming them. In contrast, cross-border strategic alliances have probably hurt customers in the EU; suggesting that not all cross-border corporate acts have the same effects. More nuance is clearly needed in policy debates so that cross-border inter-firm measures are not automatically branded as bad or anti-consumer. 


\section{References}

Bank of International Settlements (BIS). (2001). Report On Consolidation In The Financial Sector. Basle.

Berger, Allen N., Robert DeYoung, Hensa Genay, and Gregory F. Udell. (2000). "Globalization of Financial Institutions: Evidence from Cross-Border Banking Performance," Brookings-Wharton Papers on Financial Services, volume 3.

Bhagwati, Jagdish N. (1968), The Theory and Practice of Commercial Policy. Princeton, N.J.: Princeton University Press.

Black, Bernard S. (2000a). "Is This the First International Merger Wave?" M\&A Lawyer, July/August 2000: 20-26.

Black, Bernard S. (2000b). "The First International Merger Wave (and the Fifth and Last U.S. Wave," University of Miami Law Review: 799-818.

Calomiris, Charles W., and Jason Karceski. (2000). "Is the Bank Merger Wave of the 1990s Efficient? Lessons from Nine Case Studies." In Steven N. Kaplan (ed.) Mergers and Productivity. National Bureau of Economic Research.

Carow, Kenneth A., and Edward J. Kane. (2001). "Event-Study Evidence On The Value Of Relaxing Longstanding Regulatory Restraints on Banks, 1970-2000.” Mimeo. Boston College.

Consumer Union Trust Society (CUTS) (2003). Pulling Up Our Socks: A Study of Competition Regimes of Seven Developing Countries of Africa and Asia. Jaipur, India.

Dermine, Jean. (1999). "The Economics of Bank Mergers in the European Union, a Review of the Public Policy Issues.” Mimeo. INSEAD.

Evenett, Simon J., Alexander Lehmann, and Benn Steil (editors). (2000). Antitrust Goes Global: What Future for Transatlantic Cooperation? Washington, D.C.: The Brookings Institution Press.

Evenett, Simon J. (2002). "How Much Have Merger Review Laws Reduced Cross Border Mergers and Acquisitions? In William K. Rowley (ed.) International Merger Control: Prescriptions for Convergence, September 2002.

Evenett, Simon J. (2003a). A Study on Issues Relating to a Possible Multilateral Framework on Competition Policy, commissioned by the Secretariat of the World Trade Organization. 23 February 2003.

Evenett, Simon J. (2003b). "Do all networks facilitate international commerce? US law firms and the international market for corporate control." Available at www.wti.org and www.nber.org.

Evenett, Simon J. (2003c). "What Future for Regional Competition Policy in Latin America?" forthcoming in Robert Devlin and Antoni Estevadeordal (eds.) in Trade and Regional Integration in the Development Agenda, Washington, D.C.: The InterAmerican Development Bank. 
Feliciano, Zadia, and Robert E. Lipsey. (2002). "Foreign Entry in U.S. Manufacturing by Takeovers and the Creation of New Firms." Mimeo. Queens College and the Graduate Center, CUNY. New York.

Hoekman, Bernard M., and Petros C. Mavroidis. (2002). "Economic Development, Competition Policy and The WTO." Paper presented at a research conference on the Doha Round organized by the World Bank in Cairo. May 2002.

International Competition Policy Advisory Committee (ICPAC). (2000). Final Report. Washington, D.C.: Government Printing Office.

Kang, Nam-Hoon, and Sara Johansson. (2000). "Cross-border Mergers and Acquisitions: Their Role in Industrial Globalisation." STI Working paper number 2000/1. OECD. Paris.

Levenstein, Margaret C., and Valerie Y. Suslow. (2001). "Private International Cartels and The Effect on Developing Countries." Background Paper to the World Development Report 2001. Washington, D.C.

Mehta, Pradeep, and Nitya Nanda. (2003). "Competition Issues with International Dimensions: How do developing countries deal with them?" Consumer Union Trust Society Centre on Competition, Investment and Economic Regulation, Jaipur, India.

Mody, Ashoka, and Shoko Negishi. (2000). "Cross-border mergers and acquisitions in East Asia: trends and implications," Finance and Development, 38(1): 6-9.

Muris, Timothy J. (2001). "Merger Enforcement in a World of Multiple Arbiters." Paper presented at the Brookings Roundtable on Trade and Investment Policy, Washington, D.C. December 2001.

Neven, Damien, and Lans Henrik Roller. (2001). "The scope for conflict in international merger review." European Economic Review.

Organisation for Economic Cooperation and Development (OECD). (2001). New Patterns of Industrial Globalisation: Cross-Border Mergers and Acquisitions and Strategic Alliances. Paris.

Organisation for Economic Cooperation and Development (OECD). (2003). Second Report by the Competition Committee on Effective Action Against Hard Core Cartels. Paris.

Pryor, Frederic M. (2001). "Dimensions Of The Worldwide Merger Boom," forthcoming in the Journal of Economic Issues.

Rowley, William K. (2002). (ed.) International Merger Control: Prescriptions for Convergence, September 2002.

United Nations Conference on Trade and Development (UNCTAD). Various Years. World Investment Report. Geneva.

Vives, Xavier. (2001). "Competition in the changing world of banking," Oxford Review of Economic Policy, 17(4): 535-547. 
White \& Case. (2001). Survey of Worldwide Antitrust Merger Notification Requirements. Washington, D.C.

World Bank. (2000). The World Development Report 1999/2000, Entering the $21^{\text {st }}$ Century: The Changing Development Landscape. Washington, DC: World Bank.

World Trade Organization (WTO) (2002). Report (2002) of the Working Group on the Interaction Between Trade and Competition Policy to the General Council. WTO document WT/WGTCP/6. 9 December 2002. 


\begin{tabular}{|c|c|c|c|c|c|c|}
\hline \multirow{2}{*}{ Economy } & \multicolumn{5}{|c|}{ Year } & \multirow{2}{*}{ Mean ratio } \\
\hline & 1995 & 1996 & 1997 & 1998 & 1999 & \\
\hline Spain & 20.40 & 22.22 & 63.91 & 48.05 & 56.14 & 42.14 \\
\hline France & 31.81 & 61.82 & 76.59 & 57.25 & 59.02 & 57.30 \\
\hline Sweden & 65.39 & 76.19 & 30.35 & 56.71 & 99.42 & 65.61 \\
\hline Netherlands & 29.52 & 23.51 & 131.73 & 46.44 & 113.95 & 69.03 \\
\hline Belgium and Luxembourg & 18.62 & 63.82 & 78.65 & 30.41 & 153.98 & 69.10 \\
\hline United States & 90.58 & 80.60 & 77.46 & 112.47 & 84.57 & 89.14 \\
\hline Canada & 124.95 & 112.48 & 72.36 & 75.71 & 99.07 & 96.92 \\
\hline Switzerland & 166.08 & 143.18 & 53.42 & 71.25 & 120.54 & 110.89 \\
\hline Germany & 62.34 & 181.44 & 106.84 & 90.00 & 156.36 & 119.39 \\
\hline Italy & 84.72 & 77.95 & 90.86 & 146.17 & 225.24 & 124.99 \\
\hline United Kingdom & 182.24 & 127.98 & 119.50 & 143.10 & 152.59 & 145.08 \\
\hline Australia & 140.27 & 213.79 & 191.33 & 232.26 & 192.77 & 194.09 \\
\hline Japan & 1387.18 & 859.50 & 96.34 & 126.00 & 124.46 & 518.70 \\
\hline $\begin{array}{l}\text { Weighted mean (across } \\
\text { economies) }\end{array}$ & 84.60 & 87.16 & 86.75 & 96.89 & 102.75 & \\
\hline Coefficient of variation & 4.32 & 2.51 & 0.47 & 0.58 & 0.48 & \\
\hline
\end{tabular}

Source: Appendices of the World Investment Report 2000. 


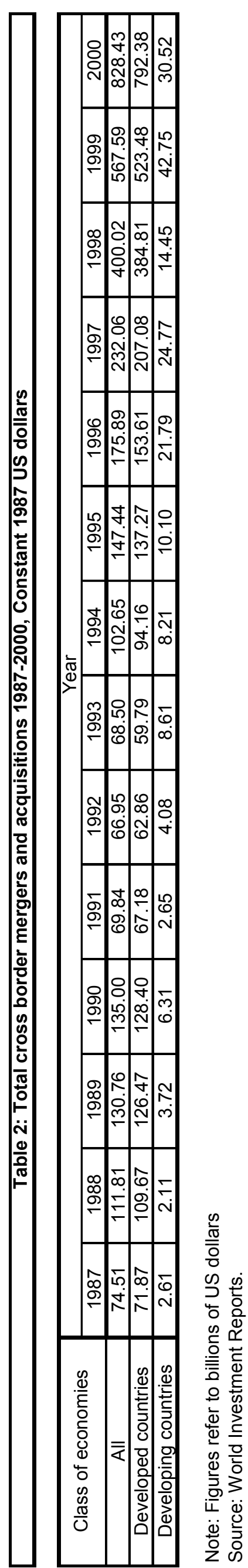




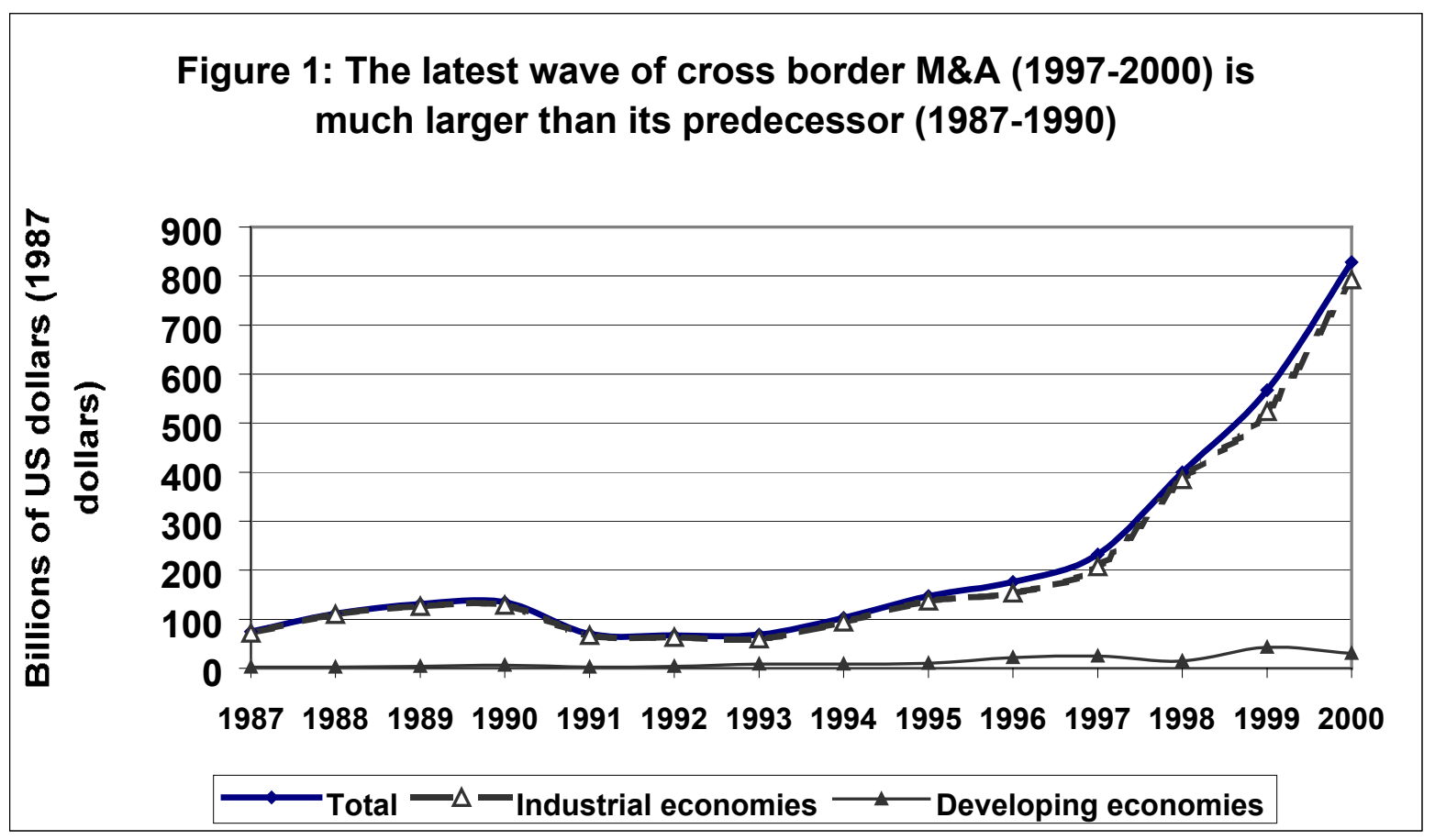

Figure 2: The real increase in cross border M\&A throughout the 1990s dwarfs that of world trade and GDP

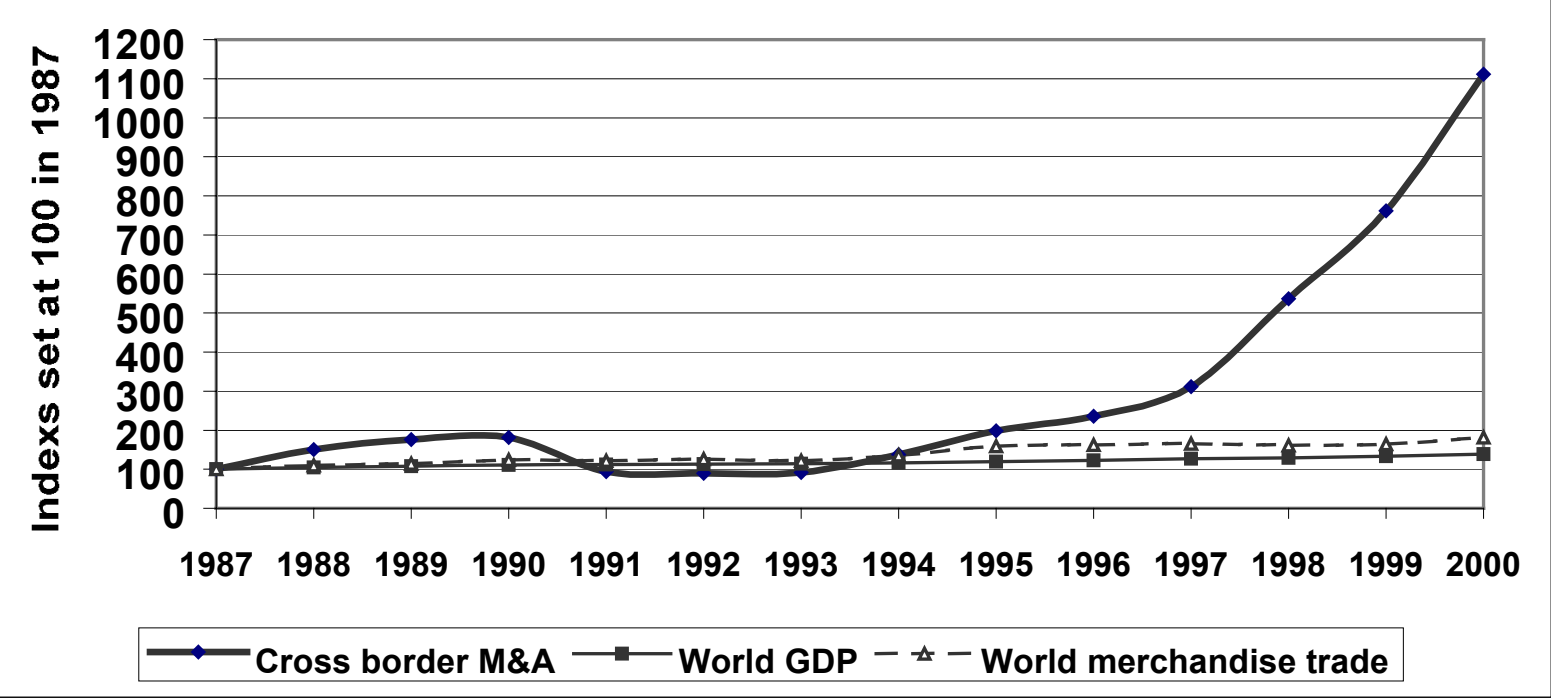



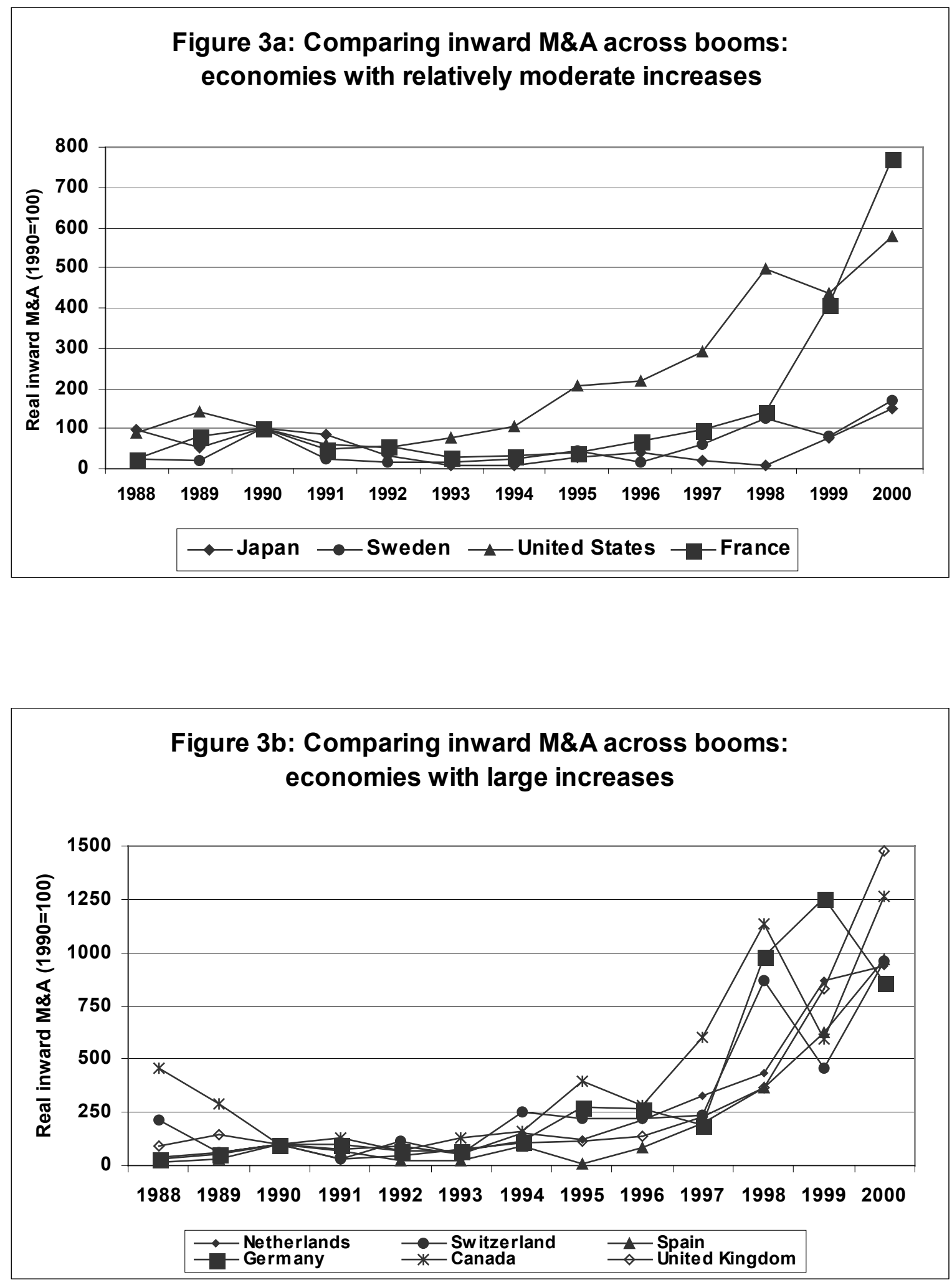


\section{Table 3:}

\begin{tabular}{|c|c|c|c|c|c|c|c|c|}
\hline \multirow{3}{*}{ Economy } & \multicolumn{8}{|c|}{$\begin{array}{c}\text { Total value of annual cross border M\&A deals as a percentage of stock market } \\
\text { capitalization }\end{array}$} \\
\hline & \multicolumn{4}{|c|}{ 1980s wave } & \multicolumn{4}{|c|}{ 1990s wave } \\
\hline & 1988 & 1989 & 1990 & Mean & 1997 & 1996 & 1999 & Mean \\
\hline Luxembourg & 0.01 & 0.00 & 5.08 & 1.70 & 10.30 & 0.10 & 20.48 & 10.29 \\
\hline Sweden & 0.19 & 1.55 & 4.58 & 2.11 & 1.22 & 3.98 & 15.99 & 7.06 \\
\hline Belgium & 1.35 & 1.08 & 6.83 & 3.08 & 4.34 & 2.79 & 13.51 & 6.88 \\
\hline Norway & 1.67 & 2.38 & 2.56 & 2.20 & 4.00 & 2.10 & 13.66 & 6.59 \\
\hline New Zealand & 10.03 & 5.00 & 41.92 & 18.98 & 4.41 & 9.28 & 5.64 & 6.44 \\
\hline Austria & 2.85 & 0.14 & 1.65 & 1.55 & 6.32 & 10.41 & 1.15 & 5.96 \\
\hline Netherlands & 1.04 & 2.51 & 1.24 & 1.60 & 4.06 & 3.21 & 5.61 & 4.30 \\
\hline Australia & 3.17 & 3.34 & 2.34 & 2.95 & 5.00 & 4.48 & 2.80 & 4.10 \\
\hline United Kingdom & 2.58 & 3.21 & 3.43 & 3.07 & 1.99 & 3.84 & 4.52 & 3.45 \\
\hline Denmark & 0.72 & 0.56 & 1.27 & 0.85 & 0.60 & 3.85 & 4.38 & 2.94 \\
\hline Canada & 3.61 & 3.57 & 2.37 & 3.19 & 1.50 & 3.02 & 2.99 & 2.50 \\
\hline France & 1.23 & 0.91 & 2.60 & 1.58 & 2.63 & 1.70 & 1.62 & 1.98 \\
\hline Germany & 0.52 & 1.18 & 1.75 & 1.15 & 1.44 & 1.74 & 2.76 & 1.98 \\
\hline Finland & 0.27 & 0.75 & 0.22 & 0.41 & 1.00 & 3.09 & 0.90 & 1.67 \\
\hline Spain & 0.79 & 1.30 & 3.44 & 1.84 & 1.40 & 1.42 & 1.35 & 1.39 \\
\hline United States & 2.29 & 1.96 & 1.79 & 2.01 & 0.72 & 1.56 & 1.51 & 1.26 \\
\hline Italy & 2.29 & 1.77 & 1.46 & 1.84 & 0.98 & 0.79 & 1.54 & 1.10 \\
\hline Switzerland & 1.67 & 0.57 & 2.85 & 1.70 & 0.62 & 0.78 & 0.59 & 0.66 \\
\hline Portugal & 0.15 & 7.23 & 2.31 & 3.23 & 0.22 & 0.68 & 0.32 & 0.41 \\
\hline Japan & 0.00 & 0.04 & 0.01 & 0.01 & 0.14 & 0.16 & 0.36 & 0.22 \\
\hline Greece & 0.51 & 0.00 & 0.76 & 0.42 & 0.29 & 0.03 & 0.09 & 0.14 \\
\hline
\end{tabular}



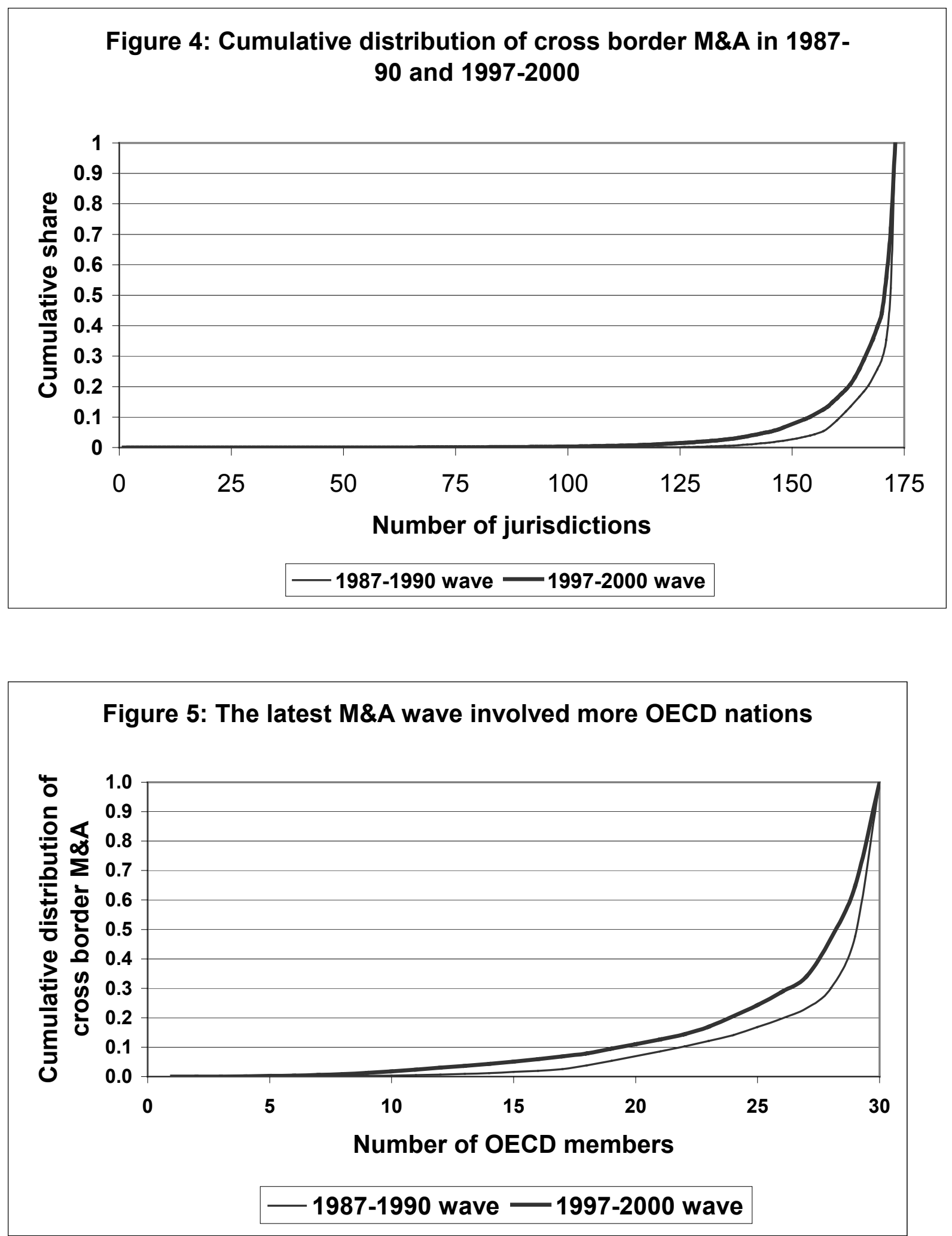


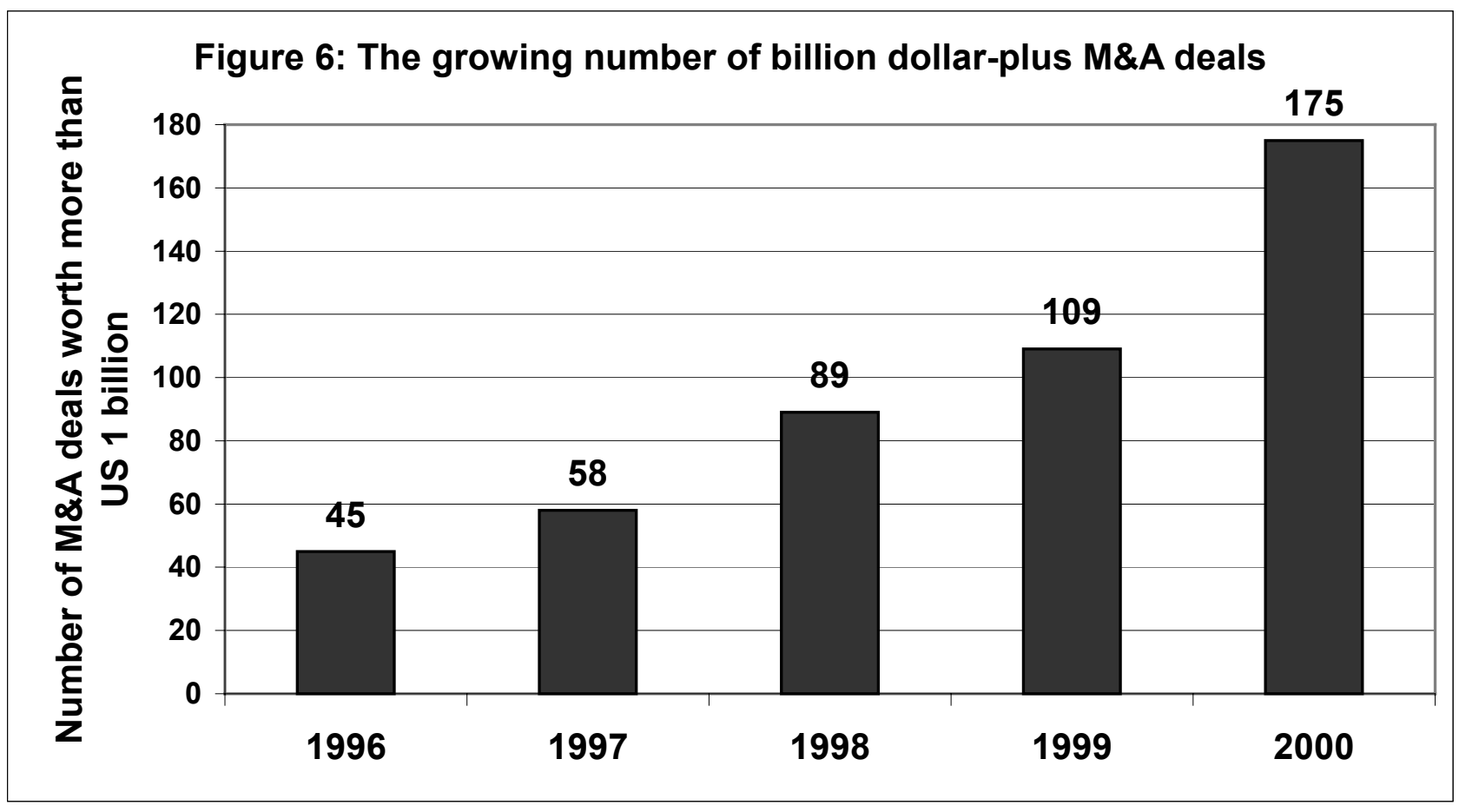

Figure 7: Mega deals drove the latest wave of cross border M\&A

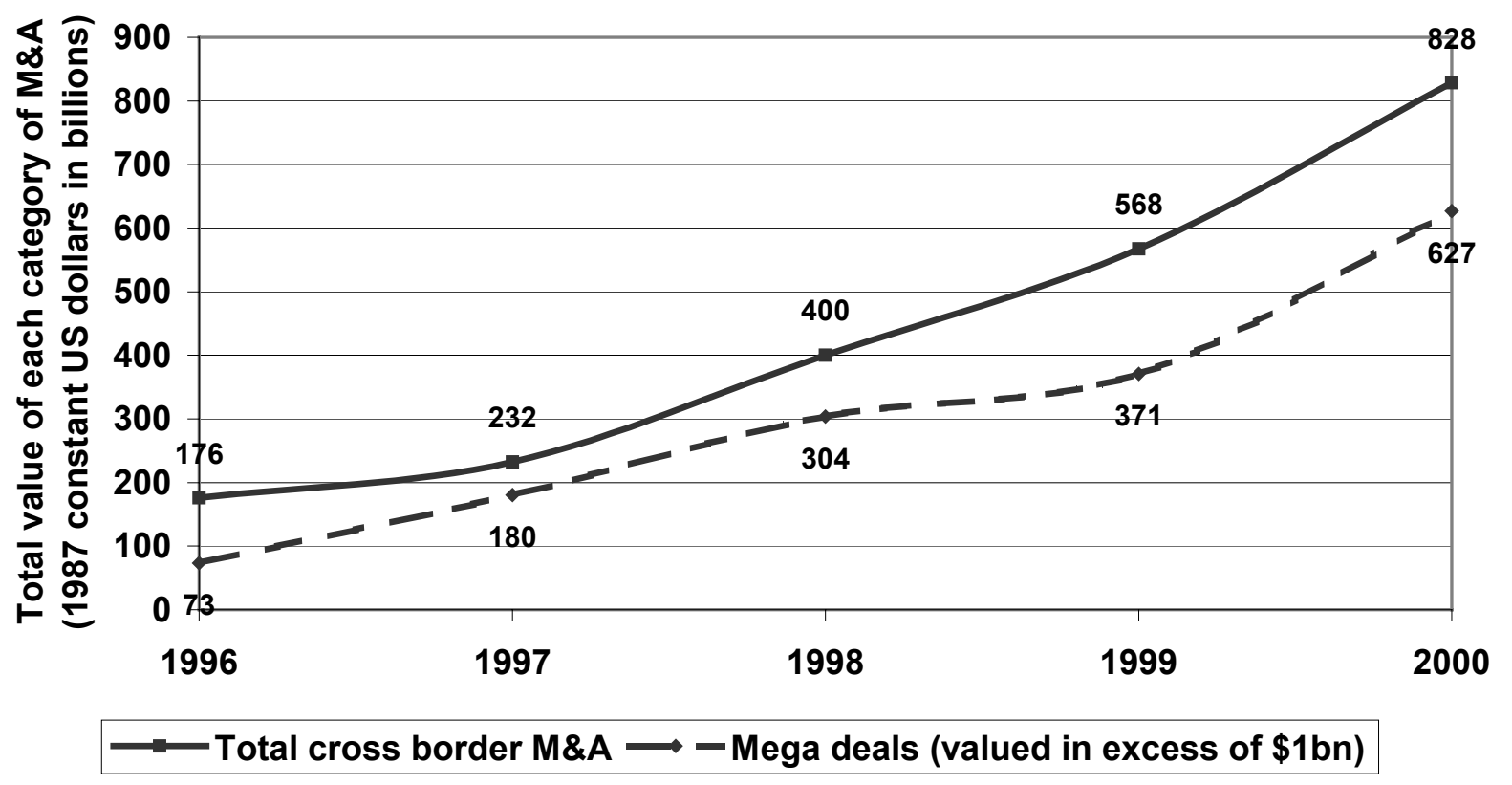


Figure 8a: Manufacturing dominated the 1987-1990 wave

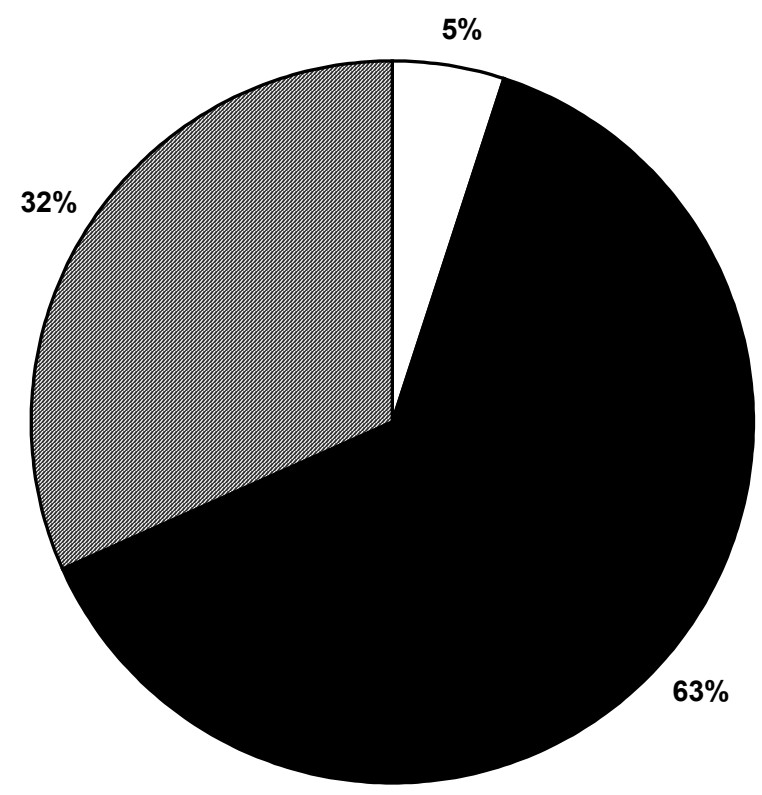

$\square$ Primary $\square$ Manufacturing $\square$ Tertiary

Figure 8b: ...but services dominated the 1997-2000 wave

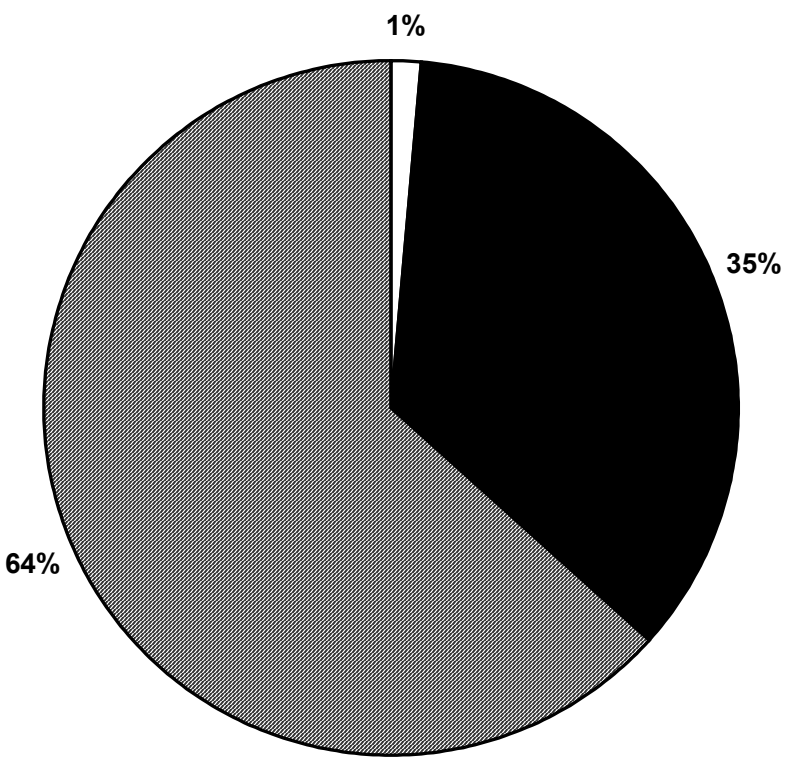


Table 4: Sectoral composition of cross border M\&A

\begin{tabular}{|c|c|c|c|}
\hline \multirow{2}{*}{ Sector } & \multirow{2}{*}{ Industy } & \multicolumn{2}{|c|}{$\begin{array}{c}\text { Share of total cross border } \\
\text { M\&A in }\end{array}$} \\
\hline & & 1987-1990 & 1997-2000 \\
\hline \multicolumn{2}{|l|}{ Primary } & 5.04 & 1.43 \\
\hline & Agriculture, hunting, forestry, and fishing & 0.72 & 0.38 \\
\hline & Mining, quarrying and petroleum & 4.32 & 1.04 \\
\hline \multicolumn{2}{|c|}{ Manufacturing } & 62.24 & 35.11 \\
\hline & Food, beverages and tobacco & 8.16 & 4.28 \\
\hline & Textiles, clothing and leather & 0.95 & 0.41 \\
\hline & Wood and wood products & 3.93 & 1.72 \\
\hline & Publishing, printing, and reproduction of recorded media & 5.89 & 1.11 \\
\hline & Coke, petroleum and nuclear fuel & 9.38 & 5.33 \\
\hline & Chemicals and chemical products & 12.17 & 6.70 \\
\hline & Rubber and plastic products & 2.03 & 0.48 \\
\hline & Non-metallic mineral products & 2.30 & 1.39 \\
\hline & Metal and metal products & 2.86 & 1.67 \\
\hline & Machinery and equipment & 1.75 & 1.69 \\
\hline & Electrical and electronic equipment & 8.14 & 5.44 \\
\hline & Precision instruments & 2.20 & 1.21 \\
\hline & Motor vehicles and other transport equipment & 1.94 & 3.60 \\
\hline & Other manufacturing & 0.53 & 0.11 \\
\hline \multicolumn{2}{|l|}{ Tertiary } & 32.72 & 63.46 \\
\hline & Electric, gas, and water & 0.36 & 5.44 \\
\hline & Construction & 0.46 & 0.38 \\
\hline & Trade & 8.08 & 5.07 \\
\hline & Hotels and restaurants & 3.77 & 0.82 \\
\hline & Transport, storage and communications & 1.84 & 21.94 \\
\hline & Finance & 11.03 & 16.19 \\
\hline & Business services & 4.39 & 9.44 \\
\hline & Public administration and defence & 0.00 & 0.08 \\
\hline & Education & 0.00 & 0.02 \\
\hline & Health and social services & 0.17 & 0.20 \\
\hline & Community, social and personal service activities & 2.62 & 3.87 \\
\hline & Other services & 0.01 & 0.01 \\
\hline \multicolumn{2}{|c|}{ Unknown } & 0.00 & 0.00 \\
\hline
\end{tabular}




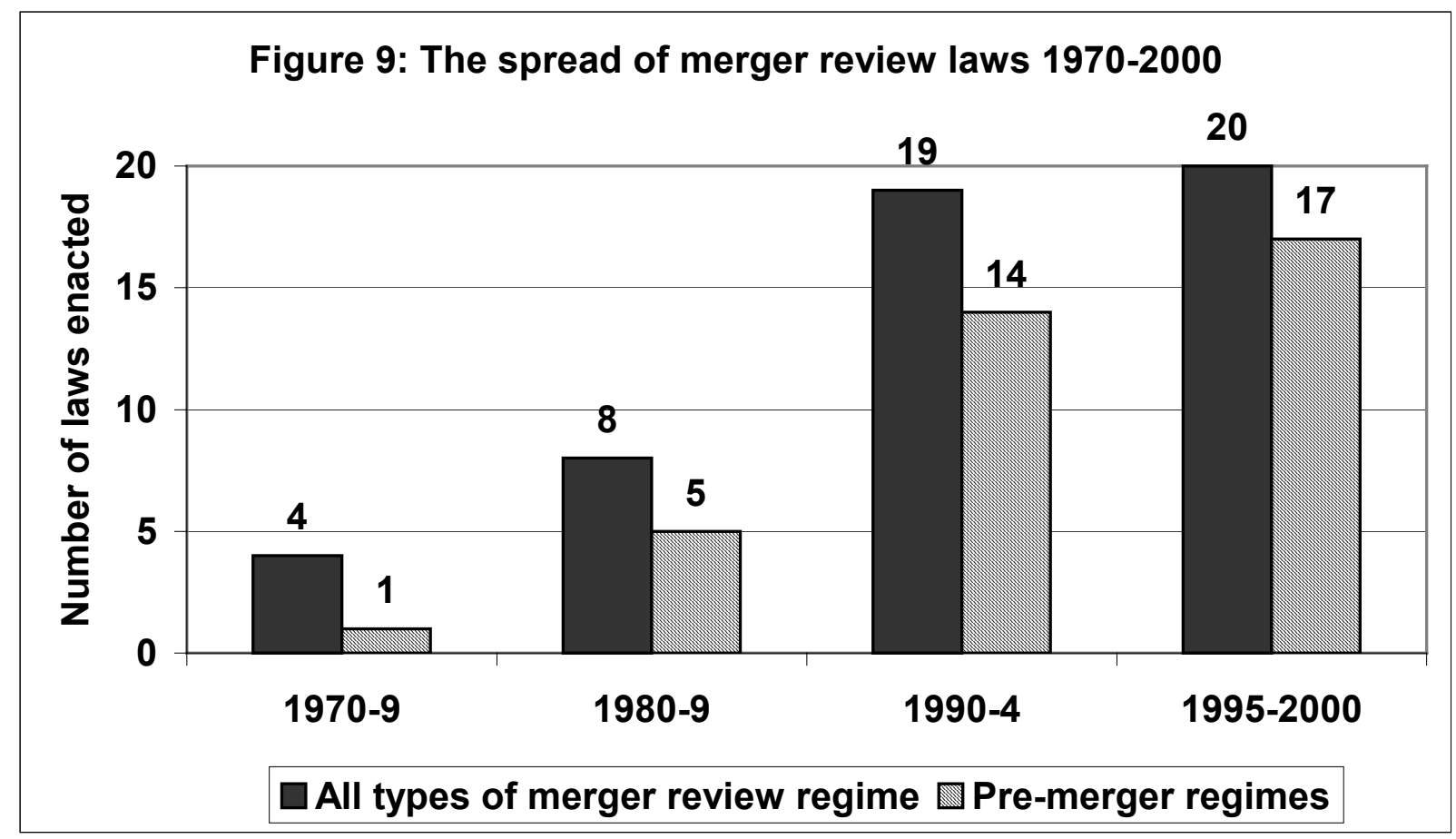




\begin{tabular}{|c|c|c|c|c|}
\hline 晋 & 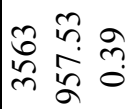 & 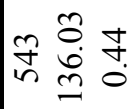 & 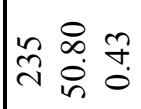 & 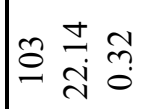 \\
\hline & - & & & \\
\hline
\end{tabular}

ڤે

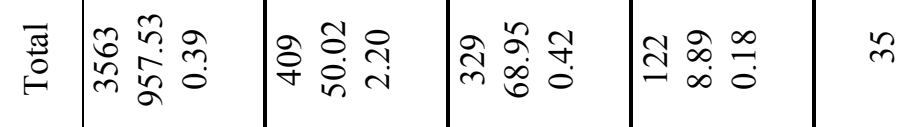

\begin{tabular}{|c|c|c|c|}
\hline 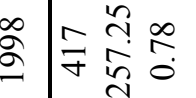 & 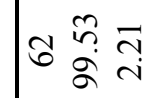 & 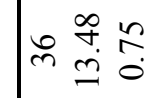 & 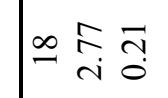 \\
\hline
\end{tabular}

\begin{tabular}{|c|c|c|c|c|}
\hline$\hat{\alpha}$ & 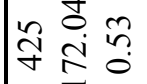 & $\vec{\nabla} \underset{+}{\vec{\sigma}}$ & 展尽 & 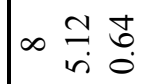 \\
\hline
\end{tabular}

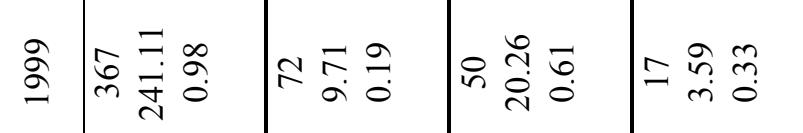

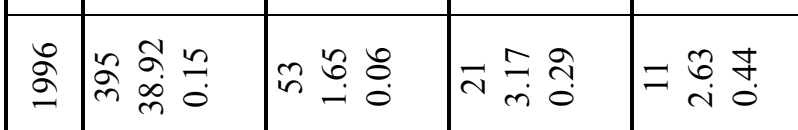

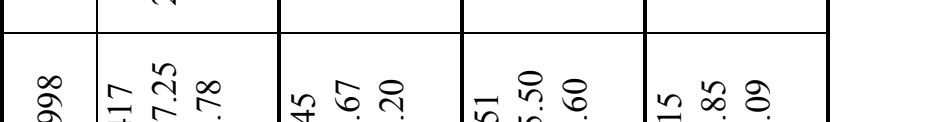

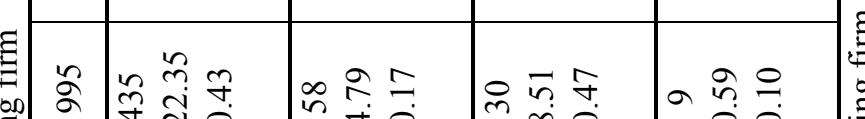

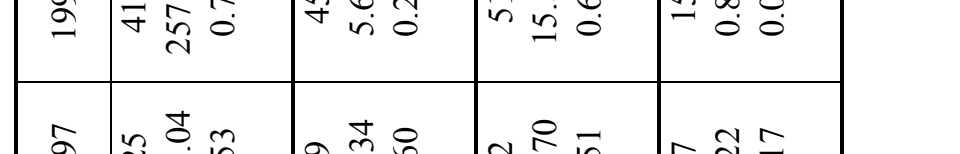

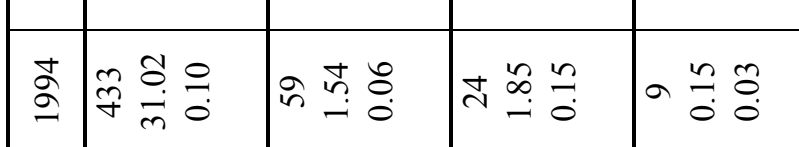

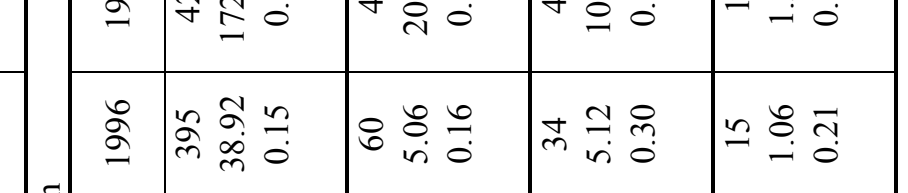

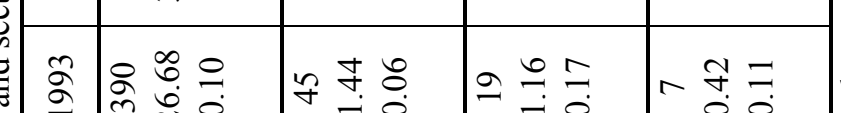

\begin{tabular}{|c|c|c|c|c|}
\hline & m ¿ $0^{\circ}$ & $\nabla-\dot{0}$ & $-\dot{0}$ & 00 \\
\hline ๙ & 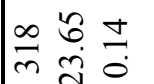 & 워 & 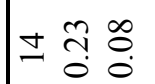 & 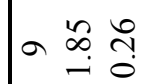 \\
\hline
\end{tabular}

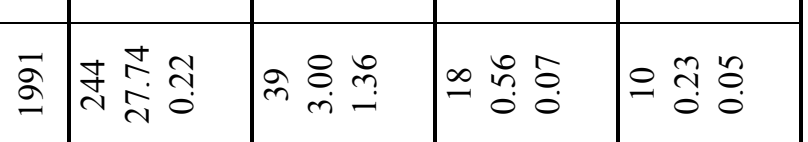

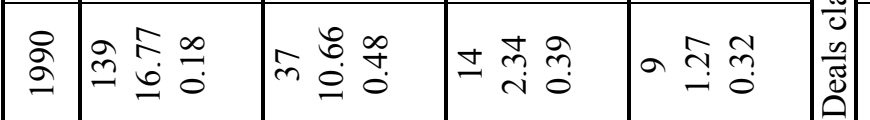

\begin{tabular}{|c|c|c|c|c|}
\hline ڤ̆ & 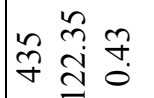 & 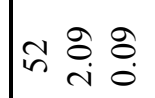 & 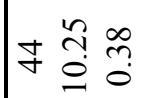 & 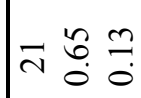 \\
\hline & No & & & \\
\hline
\end{tabular}

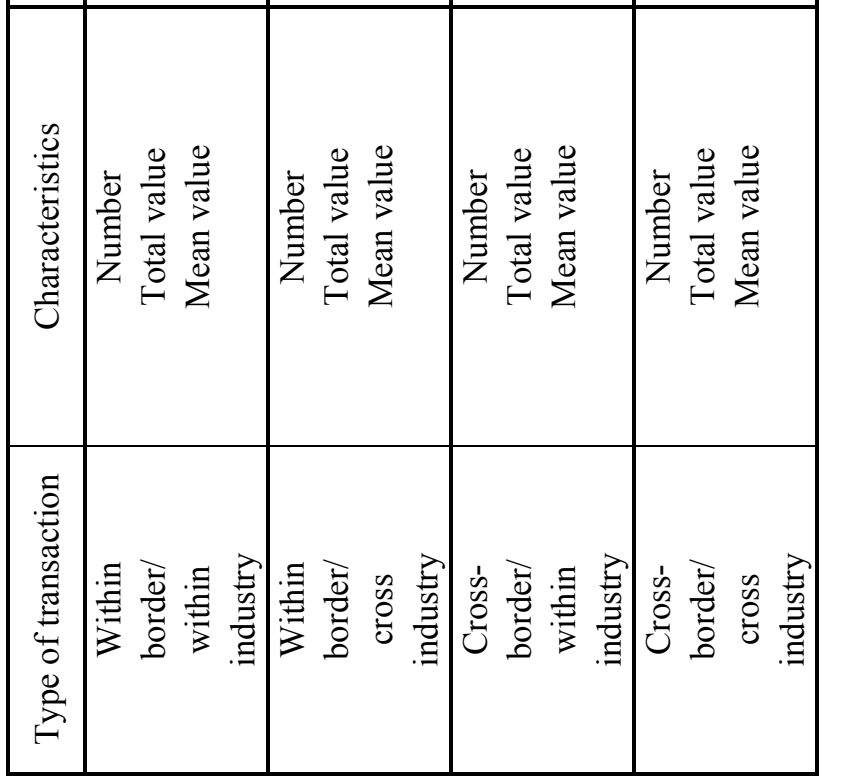

일 


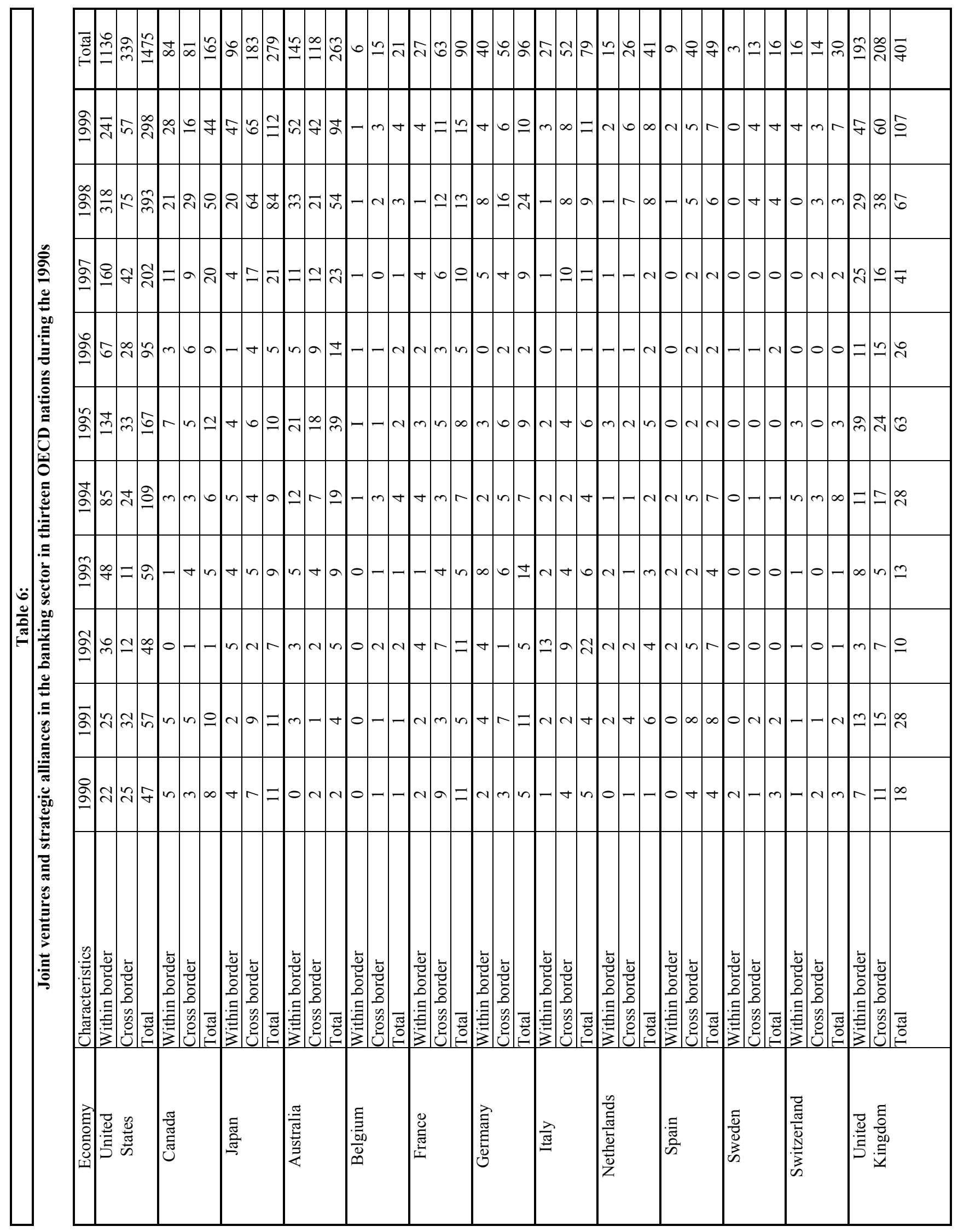




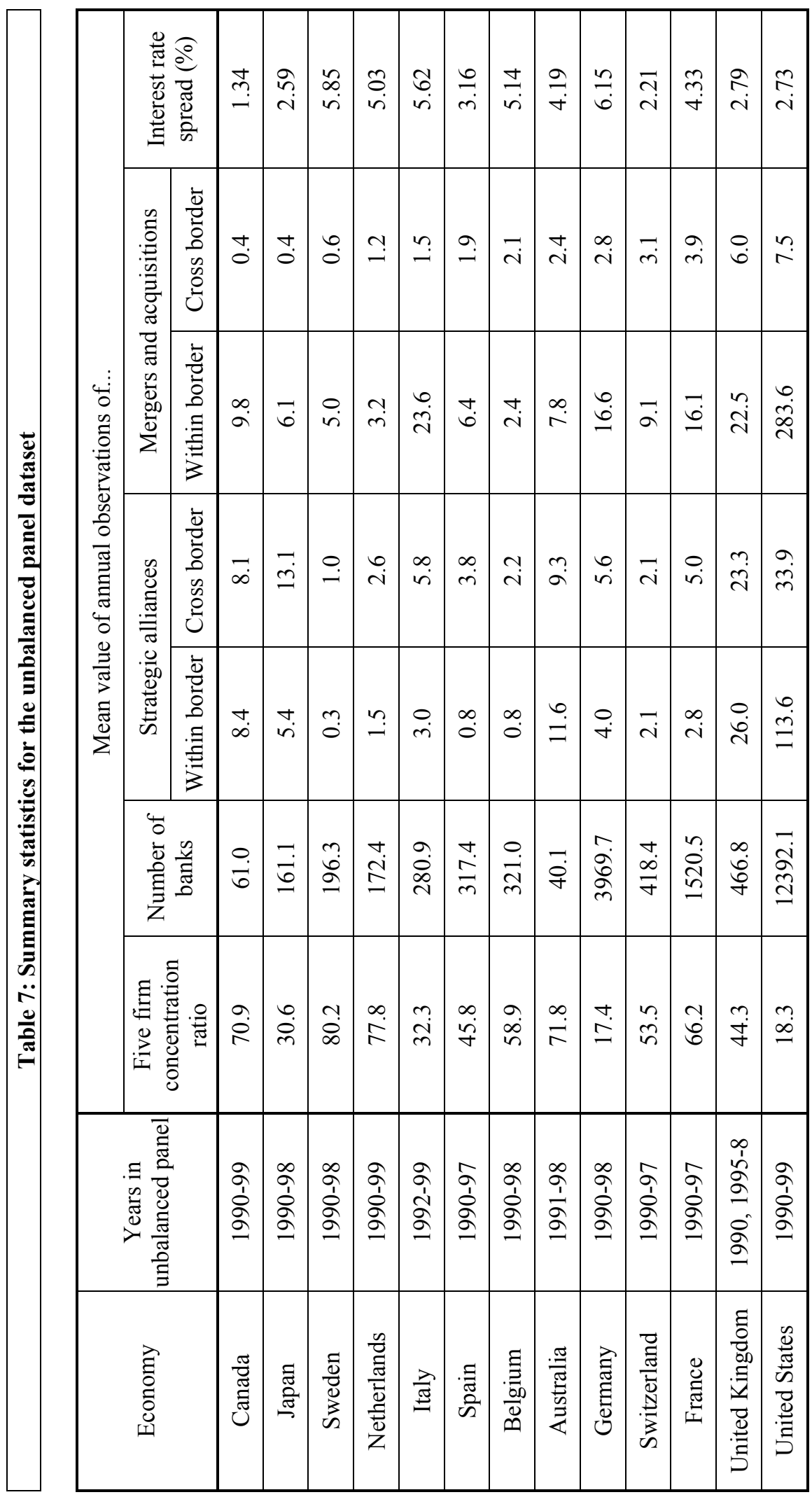




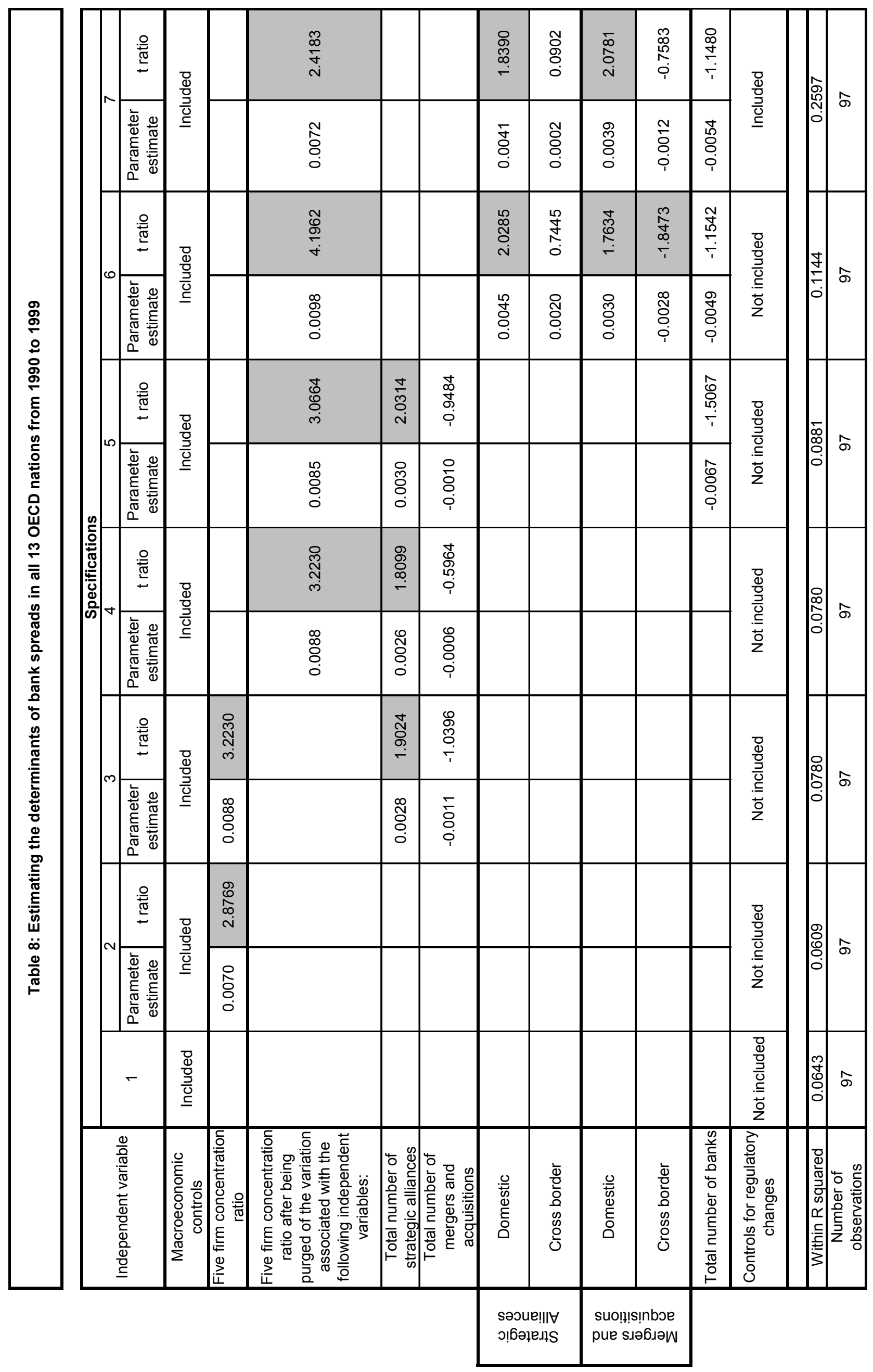




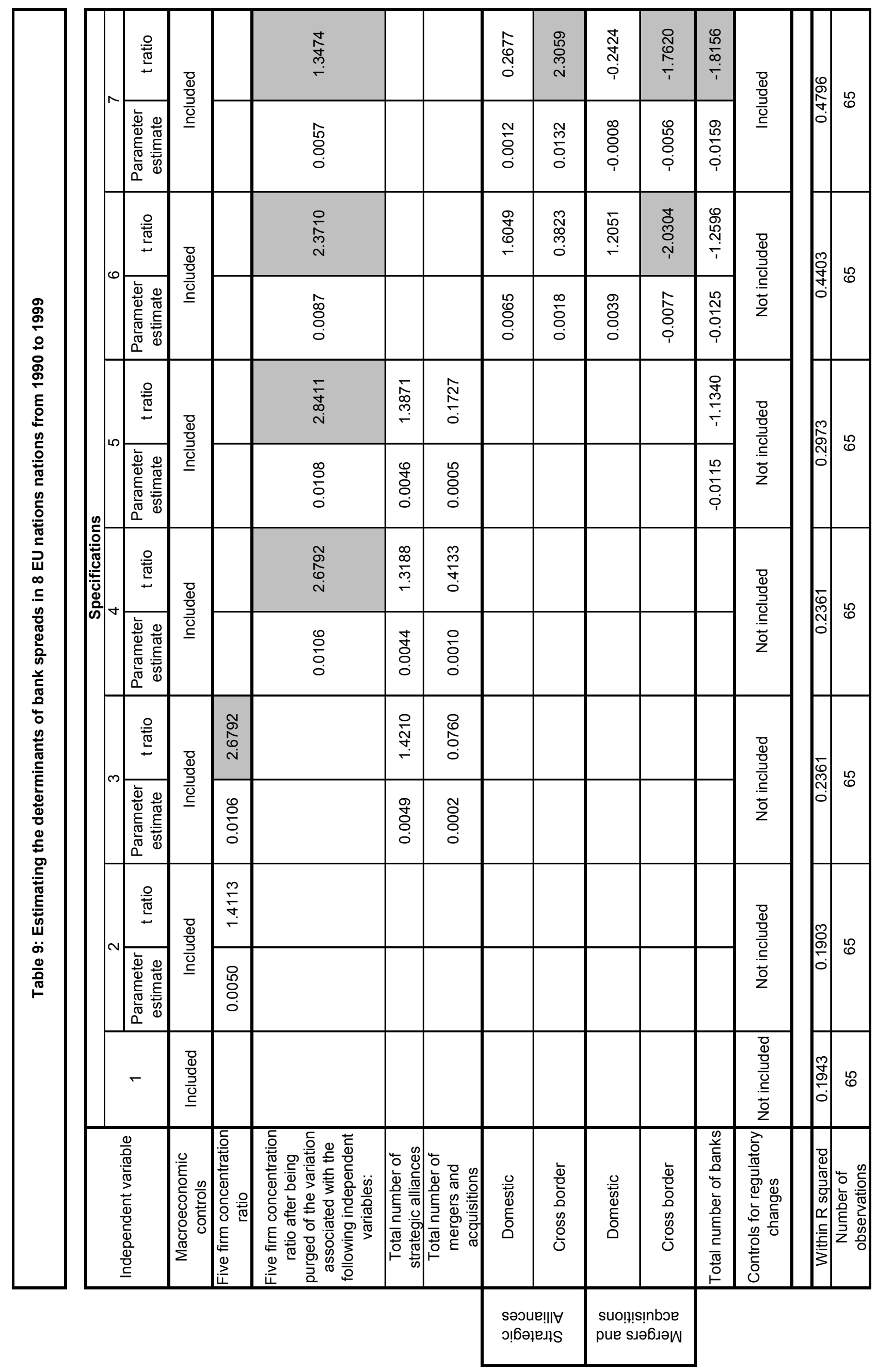




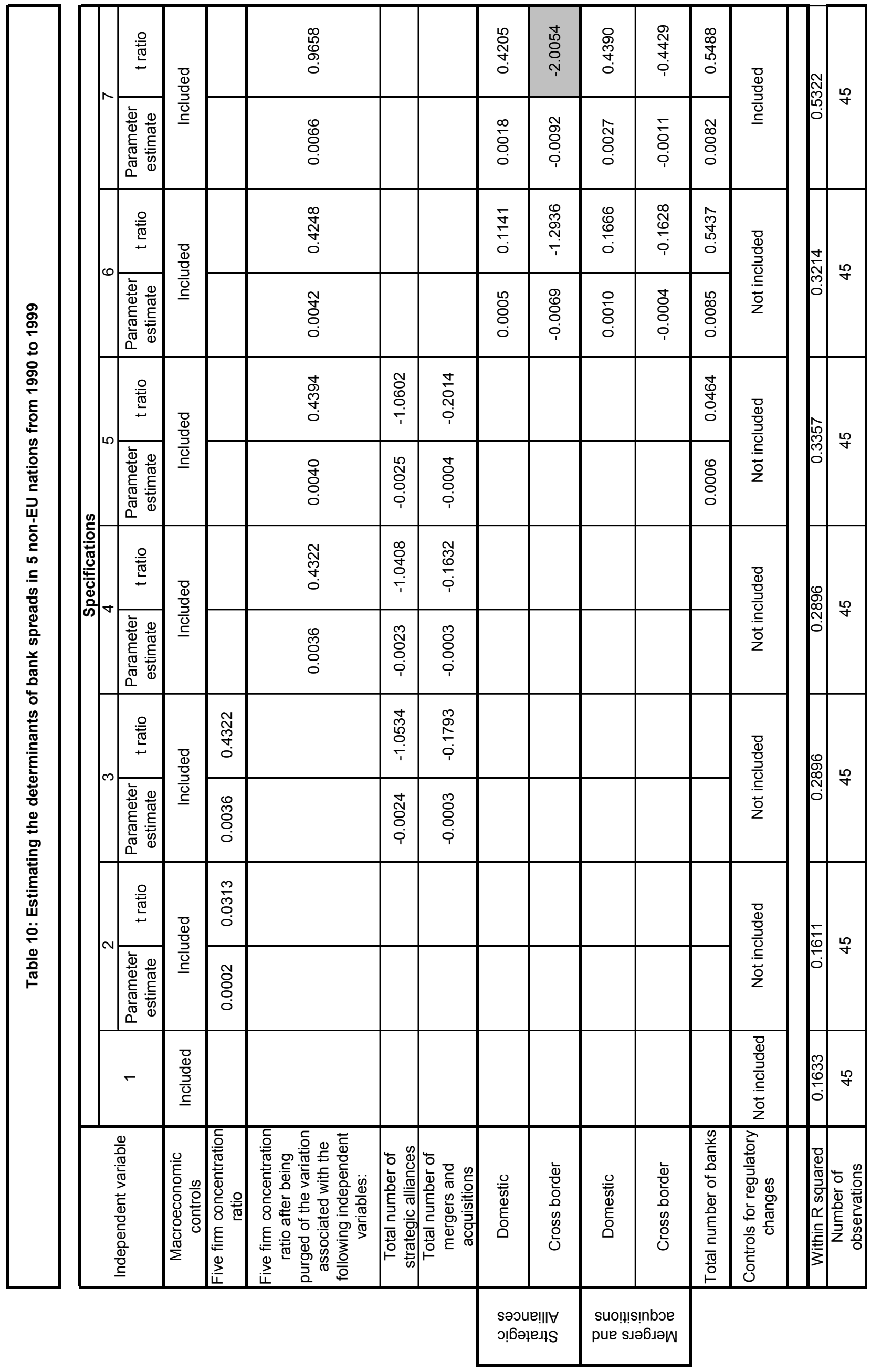




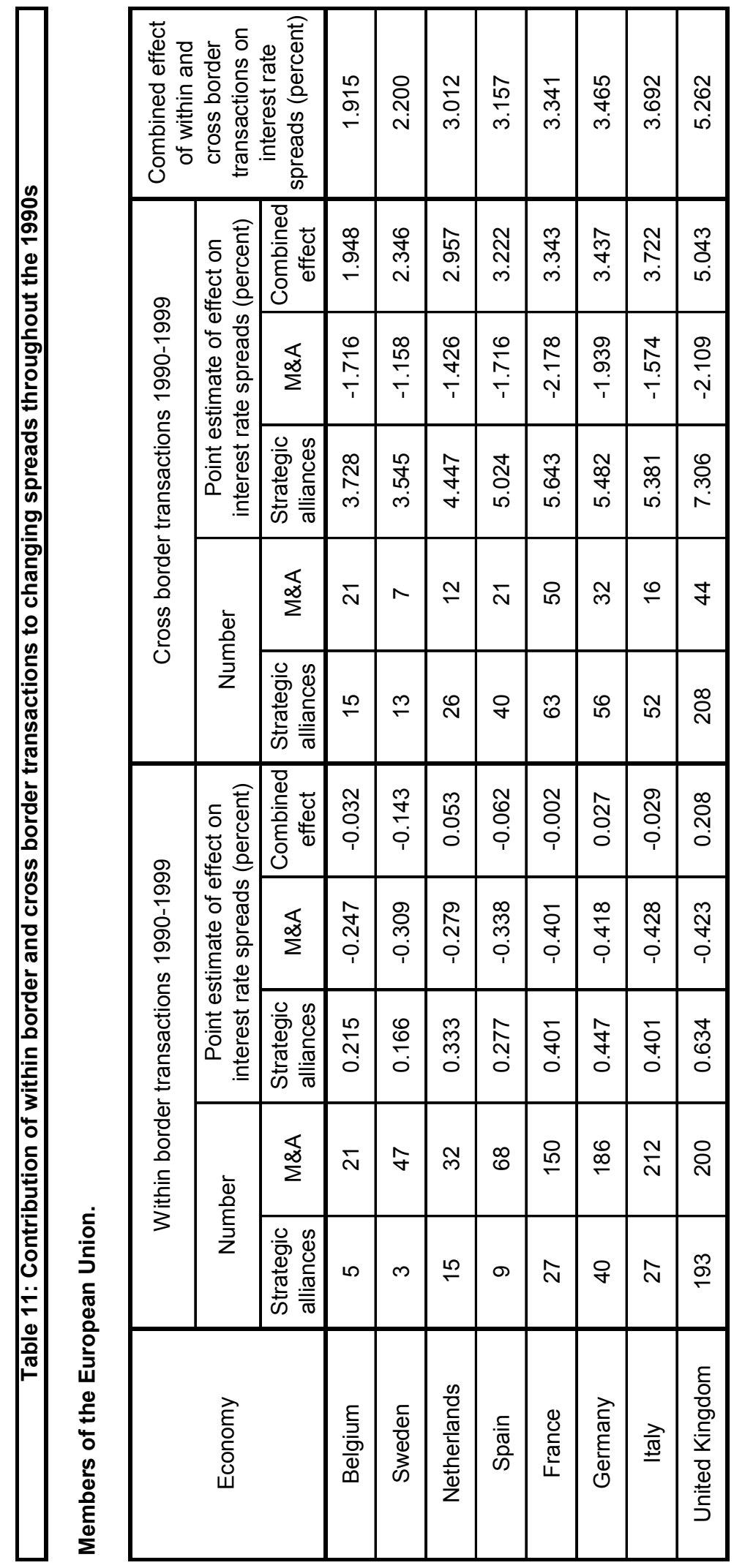

\begin{tabular}{|c|c|c|c|c|c|c|c|}
\hline \multicolumn{3}{|c|}{ 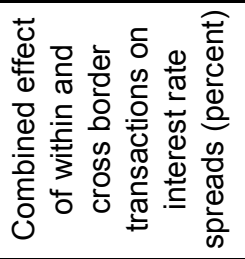 } & 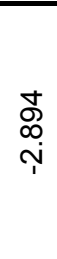 & $\begin{array}{l}\text { 오 } \\
\stackrel{\leftrightarrow}{i} \\
\text { in }\end{array}$ & $\begin{array}{l}\hat{\text { }} \\
\text { } \\
\text { i }\end{array}$ & $\frac{\hat{\theta}}{\stackrel{i}{i}}$ & $\frac{\Re}{\stackrel{n}{r}}$ \\
\hline \multirow{5}{*}{ 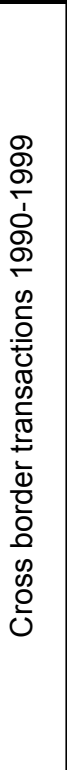 } & \multirow{3}{*}{ 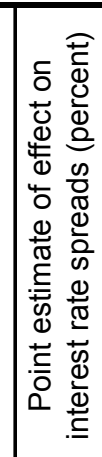 } & 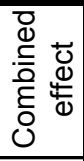 & $\begin{array}{l}\infty \\
\infty \\
\infty \\
+ \\
+\end{array}$ & 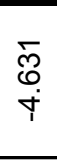 & $\begin{array}{l}\mathbb{N} \\
\stackrel{0}{6} \\
\stackrel{p}{0}\end{array}$ & $\begin{array}{l}\stackrel{P}{+} \\
\underset{+}{+}\end{array}$ & 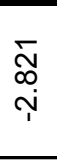 \\
\hline & & $\stackrel{\S}{\Sigma}$ & $\begin{array}{l}\stackrel{+}{N} \\
\stackrel{1}{1}\end{array}$ & 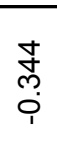 & 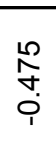 & $\frac{\hat{N}}{\stackrel{0}{i}}$ & $\begin{array}{l}0 \\
\text { m } \\
\text { Oִ }\end{array}$ \\
\hline & & 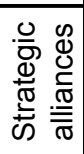 & 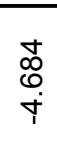 & $\begin{array}{l}\text { Oे } \\
\text { ల్ } \\
\stackrel{+}{+}\end{array}$ & 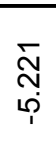 & 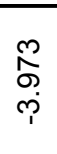 & $\begin{array}{c}\underset{\varphi}{\sigma} \\
\underset{\gamma}{\sim}\end{array}$ \\
\hline & \multirow{2}{*}{ 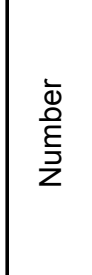 } & $\stackrel{\nwarrow}{\infty}$ & 0 & N & $\stackrel{\circ}{N}$ & $\nabla$ & $\stackrel{\sim}{\sim}$ \\
\hline & & 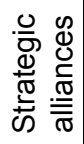 & $\stackrel{\infty}{\infty}$ & $\stackrel{\infty}{\leftarrow}$ & ल्లి & $\bar{\infty}$ & $\stackrel{\nabla}{\rightleftarrows}$ \\
\hline \multirow{5}{*}{ 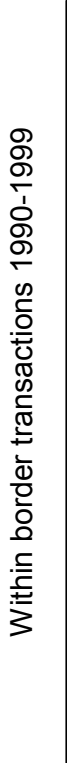 } & \multirow{3}{*}{ 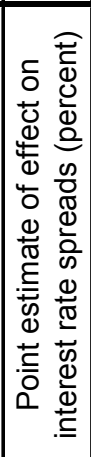 } & 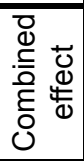 & 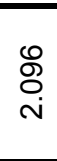 & $\begin{array}{l}\infty \\
\stackrel{\infty}{0} \\
\stackrel{N}{*}\end{array}$ & 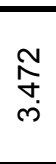 & $\begin{array}{l}\bar{\delta} \\
\stackrel{\sim}{i}\end{array}$ & 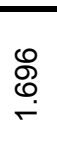 \\
\hline & & $\stackrel{\nwarrow}{\infty}$ & $\stackrel{\stackrel{\leftrightarrow}{\leftrightarrow ̣}}{\stackrel{2}{~}}$ & 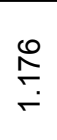 & $\stackrel{?}{\stackrel{?}{i}}$ & 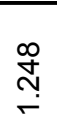 & $\stackrel{8}{\stackrel{\circ}{\leftarrow}}$ \\
\hline & & 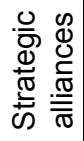 & $\begin{array}{c}\widehat{N} \\
0 \\
0 \\
0\end{array}$ & চ্ণ & 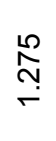 & $\begin{array}{l}0 \\
0 \\
0 \\
0 \\
0\end{array}$ & $\begin{array}{l}8 \\
\text { Lṇ } \\
0\end{array}$ \\
\hline & \multirow{2}{*}{ 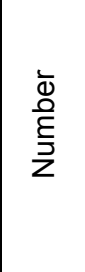 } & $\underset{\Sigma}{\infty}$ & $\stackrel{ }{\circ}$ & $\stackrel{\llcorner}{\sim}$ & $\begin{array}{l}\text { O } \\
\stackrel{\infty}{N}\end{array}$ & ळ & R \\
\hline & & 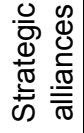 & 8 & $\stackrel{\stackrel{\rho}{\square}}{\sim}$ & $\stackrel{\mathscr{m}}{\leftarrow}$ & § & $\stackrel{20}{\sim}$ \\
\hline \multicolumn{3}{|c|}{$\begin{array}{l}\text { हे } \\
\text { Oे } \\
\text { ठ } \\
\text { ய }\end{array}$} & $\begin{array}{l}\frac{c}{\varpi} \\
\frac{\alpha}{\sigma}\end{array}$ & 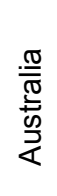 & 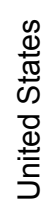 & $\begin{array}{l}\frac{\pi}{0} \\
\mathbb{\pi} \\
\stackrel{\pi}{\pi} \\
0\end{array}$ & 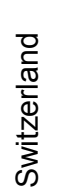 \\
\hline
\end{tabular}




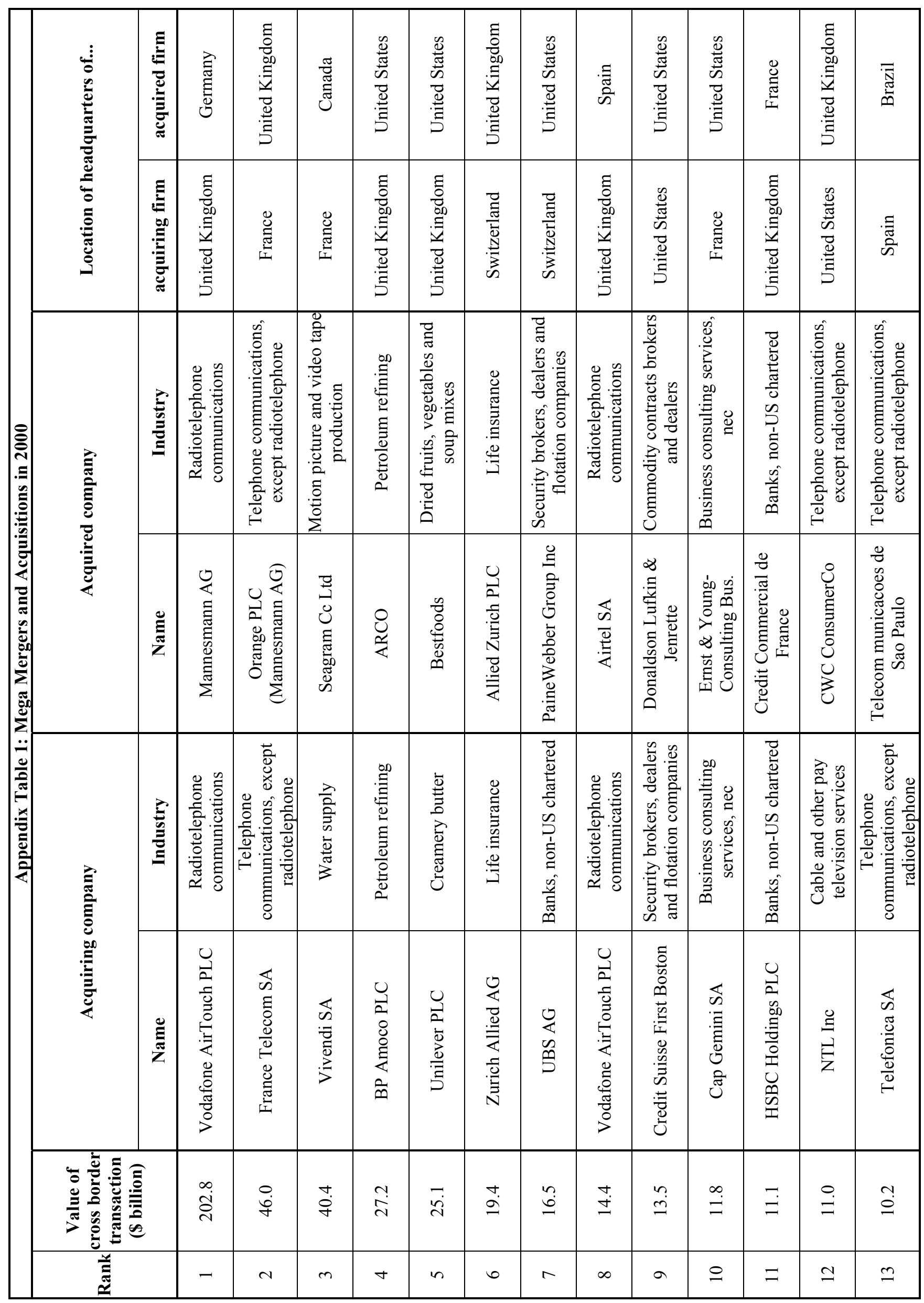




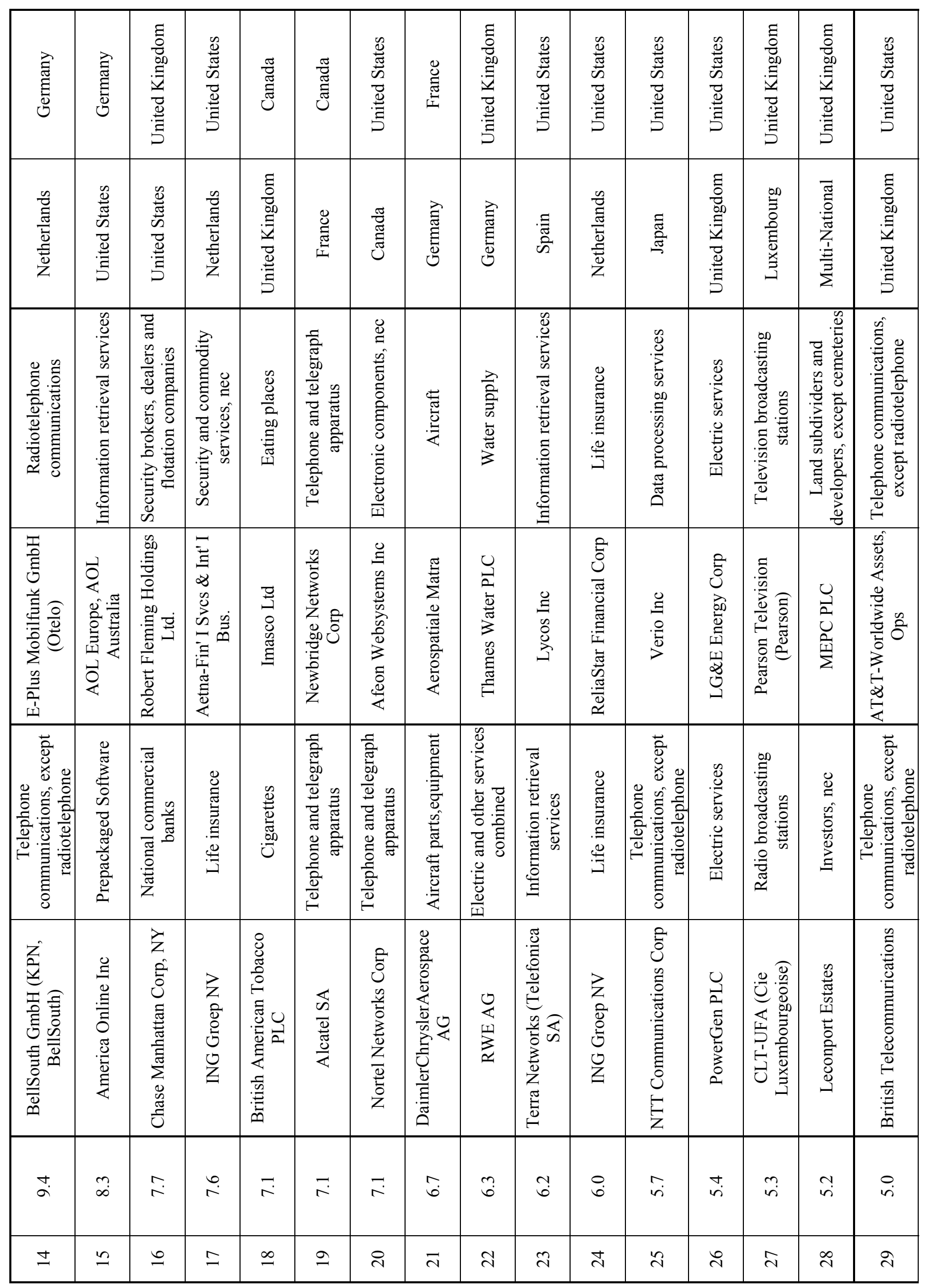




\begin{tabular}{|c|c|c|c|c|c|c|c|c|c|c|c|c|c|c|c|}
\hline 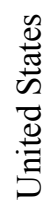 & 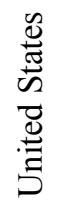 & 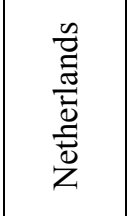 & $\begin{array}{l}\vec{\Xi} \\
\stackrel{\Xi}{\Xi}\end{array}$ & 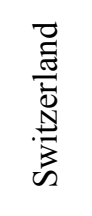 & 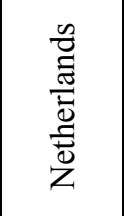 & 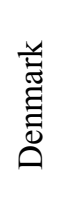 & 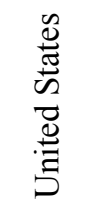 & 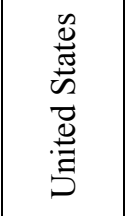 & 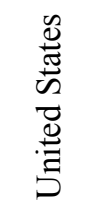 & $\begin{array}{l}\vec{\Xi} \\
\frac{\vec{t}}{0} \\
2\end{array}$ & 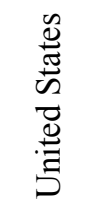 & 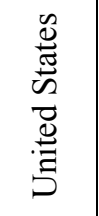 & 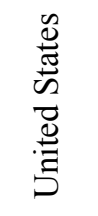 & 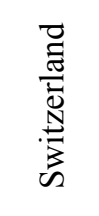 & $\begin{array}{l}\text { } \\
\stackrel{\Xi}{\Xi} \\
\stackrel{\Xi}{0}\end{array}$ \\
\hline 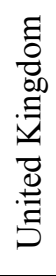 & 壳 & 齐 & 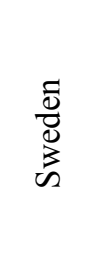 & 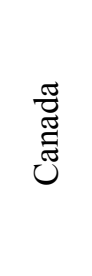 & 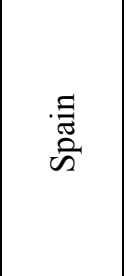 & 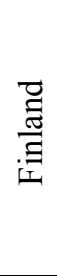 & 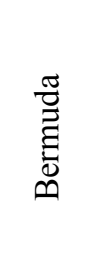 & 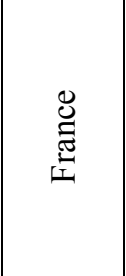 & 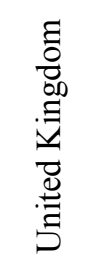 & 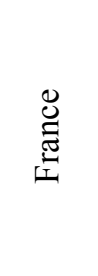 & 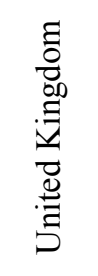 & 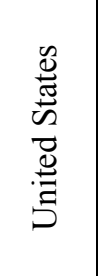 & 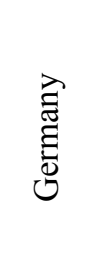 & 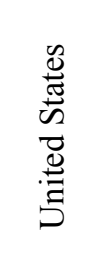 & 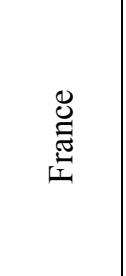 \\
\hline 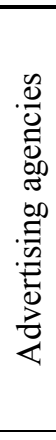 & 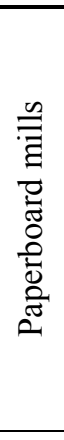 & 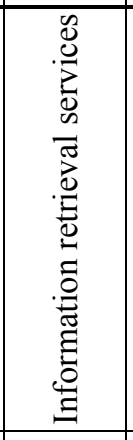 & 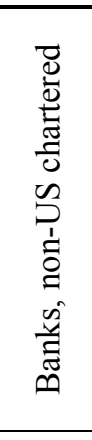 & 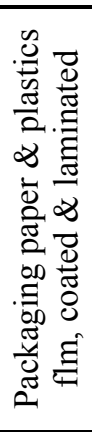 & 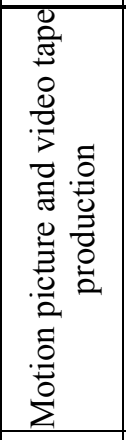 & 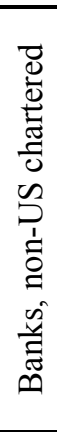 & 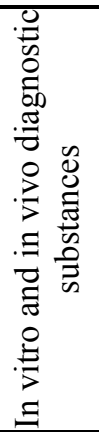 & 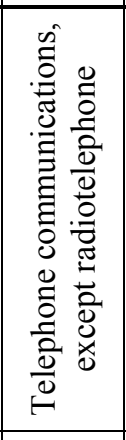 & 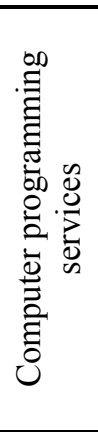 & 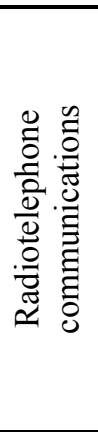 & 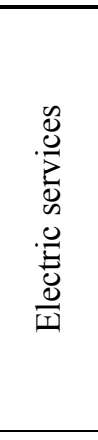 & 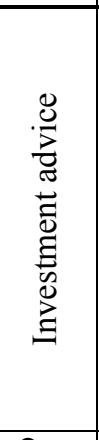 & 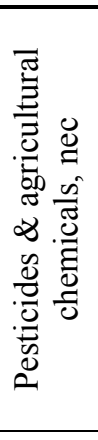 & 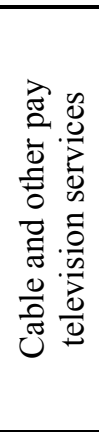 & 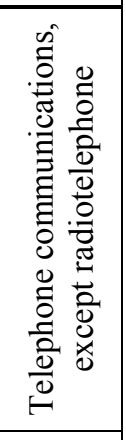 \\
\hline 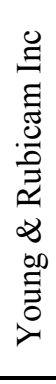 & 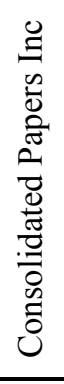 & 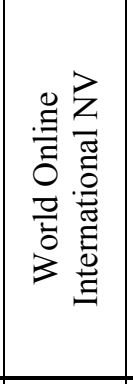 & 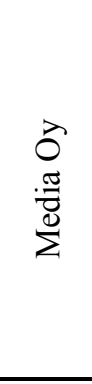 & 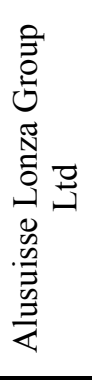 & 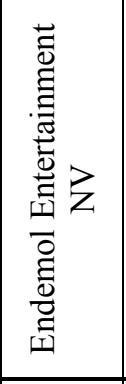 & 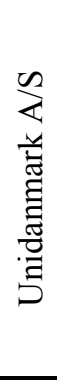 & 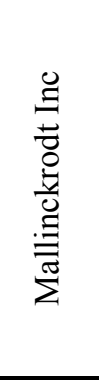 & $\begin{array}{l}0 \\
0 \\
0 \\
0 \\
\frac{0}{\tilde{E}} \\
0 \\
0 \\
0\end{array}$ & $\begin{array}{l}0 \\
\Xi \\
\Xi \\
0 \\
0 \\
\mathscr{\Xi} \\
\Xi \\
\Xi\end{array}$ & 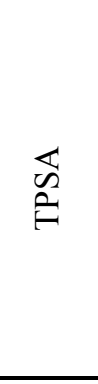 & 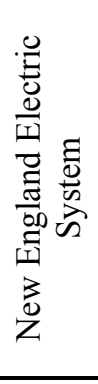 & 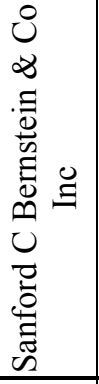 & 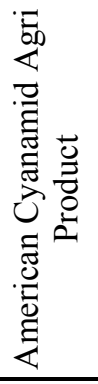 & 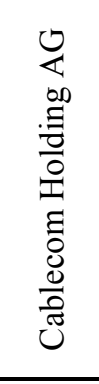 & 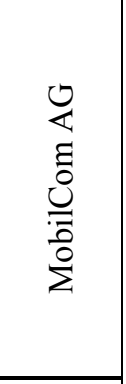 \\
\hline 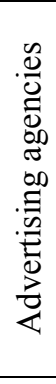 & 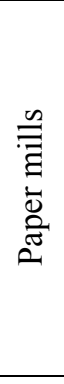 & 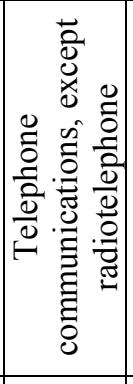 & 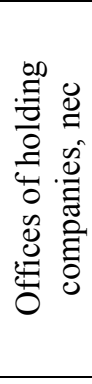 & 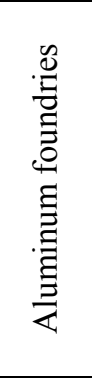 & 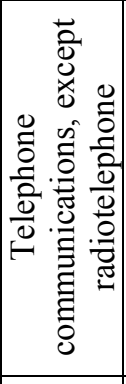 & 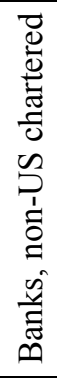 & 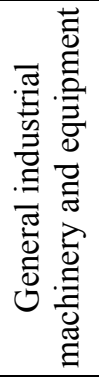 & 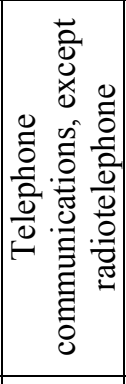 & 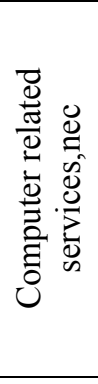 & 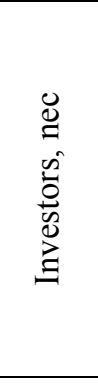 & 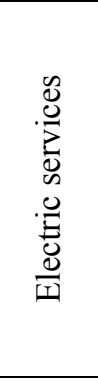 & 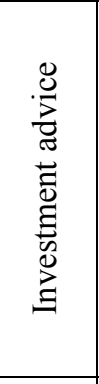 & 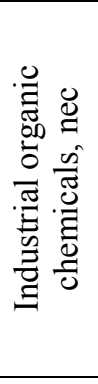 & 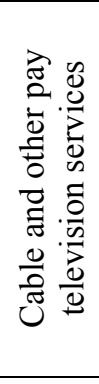 & 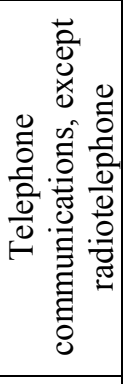 \\
\hline 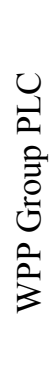 & 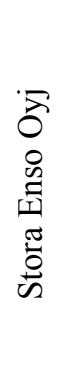 & 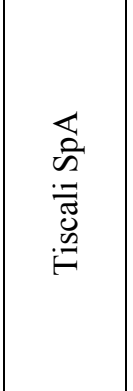 & 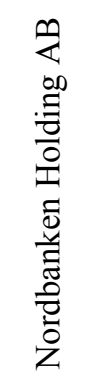 & 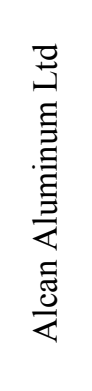 & 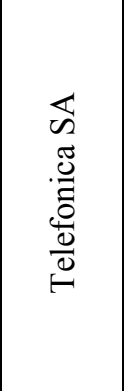 & 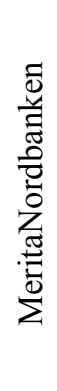 & 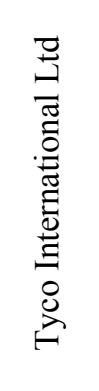 & 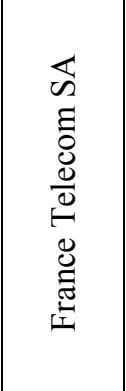 & 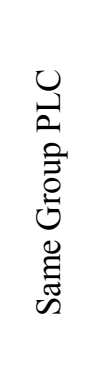 & 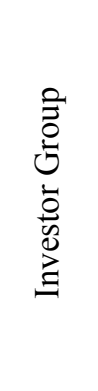 & 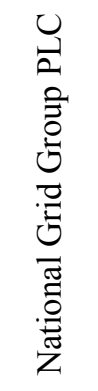 & 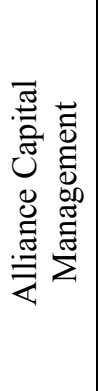 & 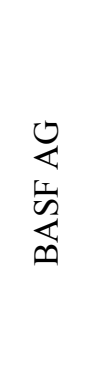 & $\begin{array}{l}\mathscr{\Xi} \\
\exists \\
\text { 兒 }\end{array}$ & 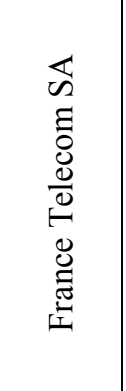 \\
\hline $\begin{array}{l}0 \\
\dot{n}\end{array}$ & $\stackrel{\vartheta}{\dot{\nabla}}$ & $\stackrel{\vartheta}{\dot{\gamma}}$ & $\stackrel{\infty}{+}$ & $\stackrel{\infty}{\stackrel{\sim}{+}}$ & $\begin{array}{l}\ominus \\
\dot{\nabla}\end{array}$ & $\stackrel{\nabla}{\forall}$ & $\stackrel{\nabla}{\forall}$ & $\stackrel{m}{+}$ & $\stackrel{n}{+}$ & $\stackrel{m}{\forall}$ & $\stackrel{\Upsilon}{\forall}$ & $\stackrel{\circ}{\stackrel{+}{*}}$ & ले & $\vec{m}$ & $\stackrel{\circ}{\dot{m}}$ \\
\hline ㅇ & $\vec{m}$ & กี & $\stackrel{m}{m}$ & m & $n$ & r & $\hat{n}$ & $\stackrel{\infty}{n}$ & ले & $\stackrel{+}{+}$ & $\bar{\nabla}$ & $\stackrel{\sim}{\sim}$ & $\stackrel{\leftrightarrow}{\sim}$ & $\underset{\forall}{\forall}$ & $\stackrel{\wp}{f}$ \\
\hline
\end{tabular}




\begin{tabular}{|c|c|c|c|c|c|c|c|c|c|c|c|c|c|c|c|}
\hline 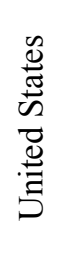 & 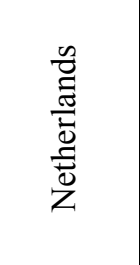 & $\frac{\vec{\pi}}{\underline{\Xi}}$ & 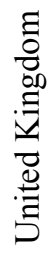 & 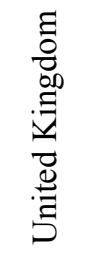 & 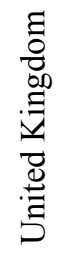 & 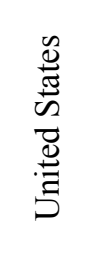 & 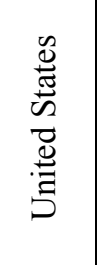 & 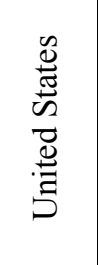 & 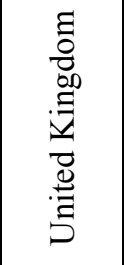 & 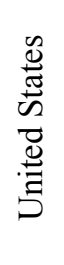 & 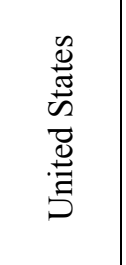 & 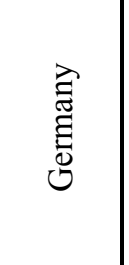 & $\begin{array}{l}\overrightarrow{\mathrm{a}} \\
\stackrel{2}{0} \\
\mathrm{Z}\end{array}$ & 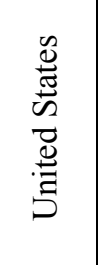 & 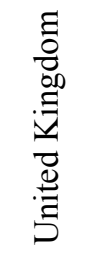 \\
\hline 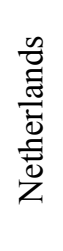 & 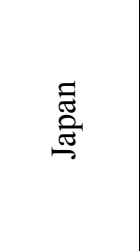 & 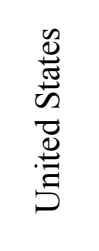 & 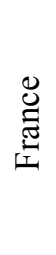 & 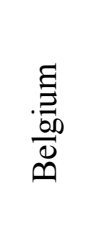 & 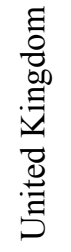 & 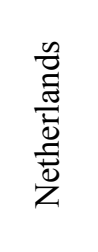 & 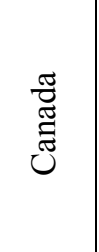 & 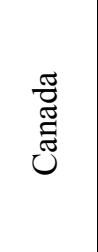 & $\begin{array}{l}\dot{D} \\
\stackrel{d}{0} \\
\dot{0}\end{array}$ & 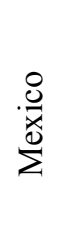 & 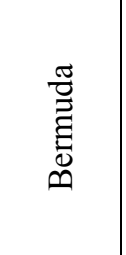 & 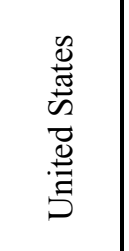 & 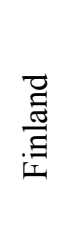 & 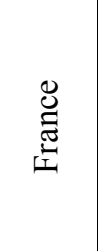 & 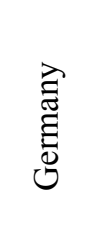 \\
\hline 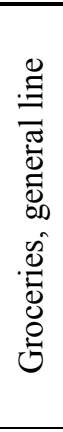 & 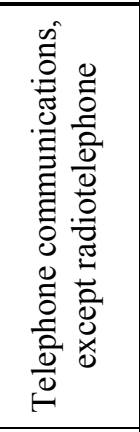 & 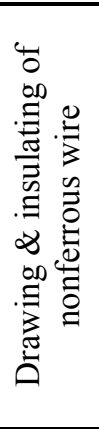 & 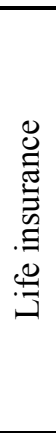 & 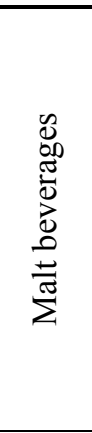 & 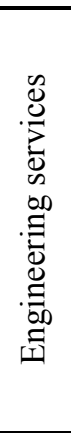 & 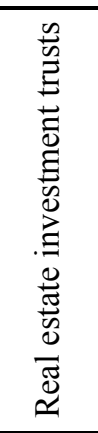 & 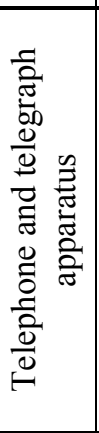 & 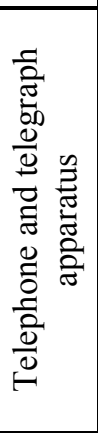 & 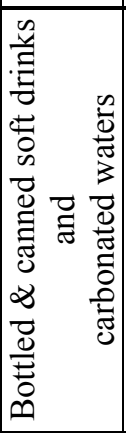 & 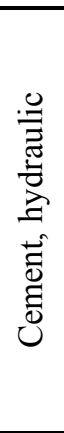 & 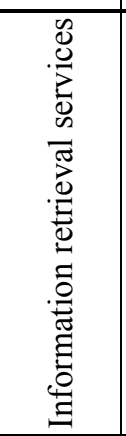 & 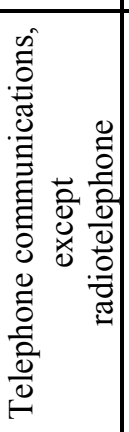 & 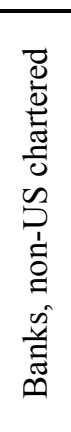 & $\begin{array}{l}0 \\
d \\
0 \\
0 \\
0 \\
0 \\
0 \\
0 \\
0 \\
0 \\
0 \\
0 \\
0 \\
0 \\
0\end{array}$ & 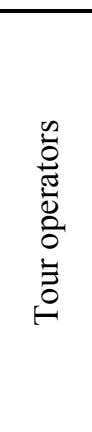 \\
\hline $\begin{array}{l}0 \\
\Xi \\
0 \\
.0 \\
2 \\
0 \\
0 \\
0 \\
0 \\
1 \\
0 \\
D\end{array}$ & 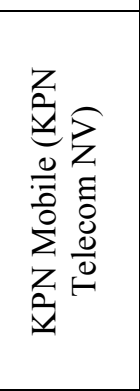 & 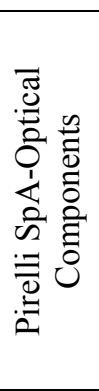 & 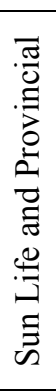 & 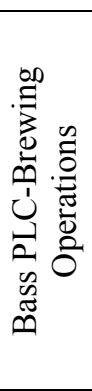 & 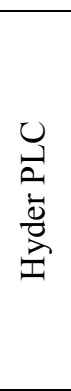 & 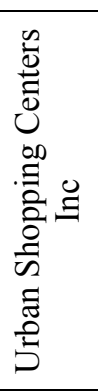 & $\begin{array}{l}\mathscr{\Xi} \\
\tilde{O} \\
0 \\
\dot{x}\end{array}$ & 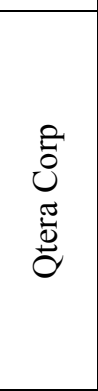 & 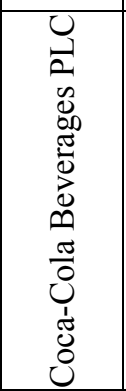 & 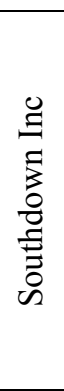 & 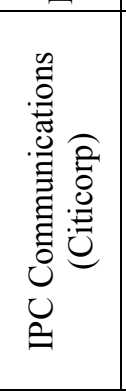 & 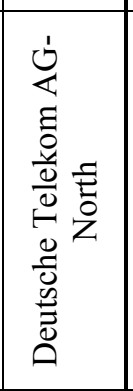 & 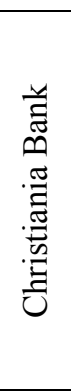 & 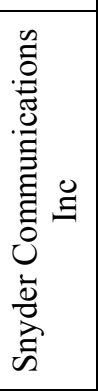 & 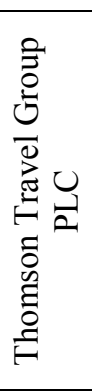 \\
\hline $\begin{array}{l}0 \\
0 \\
0 \\
0 \\
2 \\
2 \\
0 \\
0 \\
0\end{array}$ & 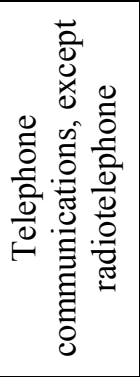 & 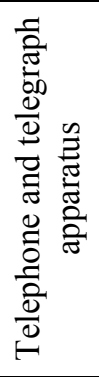 & 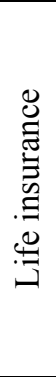 & 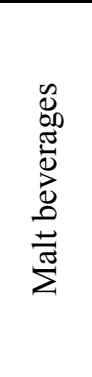 & 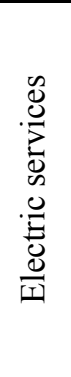 & 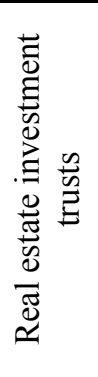 & 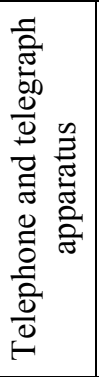 & 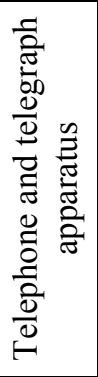 & 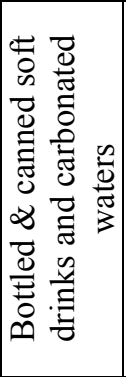 & 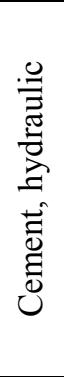 & 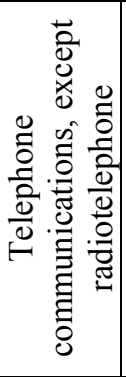 & 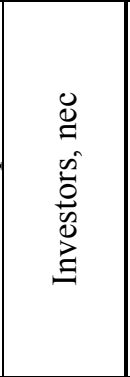 & 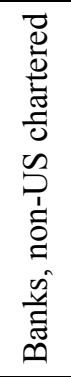 & 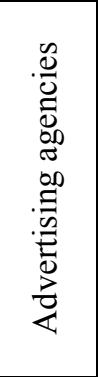 & 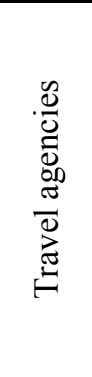 \\
\hline 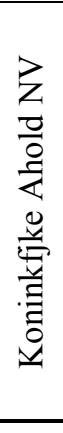 & 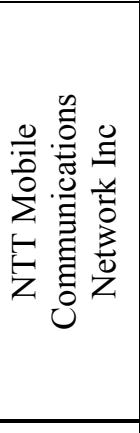 & 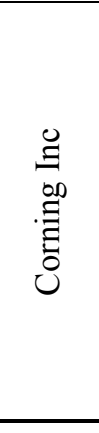 & $\underset{\mathbb{4}}{\mathbb{x}}$ & 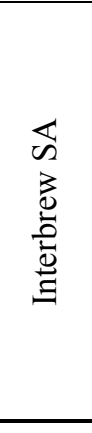 & \begin{tabular}{l}
$y$ \\
\multicolumn{1}{c}{} \\
0 \\
60 \\
$: 0$ \\
$\frac{0}{0}$ \\
0 \\
0 \\
0 \\
3
\end{tabular} & 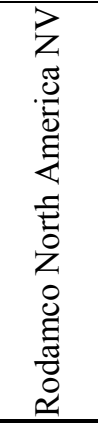 & $\begin{array}{l}0 \\
0 \\
0 \\
0 \\
0 \\
0 \\
0 \\
0 \\
0 \\
0 \\
0 \\
0 \\
z\end{array}$ & $\begin{array}{l}0 \\
0 \\
0 \\
0 \\
\vdots 0 \\
0 \\
0 \\
0 \\
0 \\
0 \\
0 \\
0\end{array}$ & 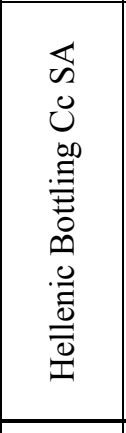 & 节 & 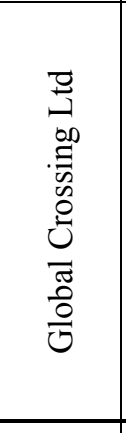 & 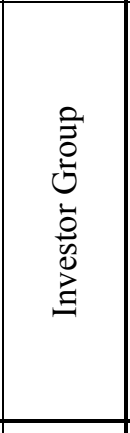 & 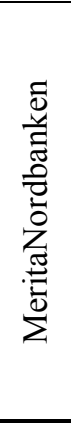 & 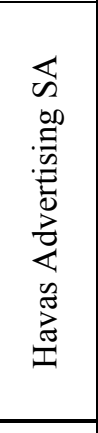 & 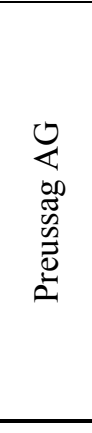 \\
\hline $\begin{array}{l}\dot{\varphi} \\
\dot{m}\end{array}$ & $\begin{array}{l}\dot{\varphi} \\
\dot{\sim}\end{array}$ & $\begin{array}{l}\dot{m} \\
\dot{m}\end{array}$ & $\tilde{n}$ & $\ddot{n}$ & $\stackrel{\forall}{\oplus}$ & $\stackrel{+}{\oplus}$ & $m$ & $m$ & $\hat{\mathrm{c}}$ & $\stackrel{\infty}{i}$ & $\stackrel{\infty}{\sim}$ & $\stackrel{\infty}{i}$ & $\stackrel{\infty}{i}$ & $\stackrel{\infty}{\sim}$ & $\bar{i}$ \\
\hline$\stackrel{\circ}{+}$ & F & $\stackrel{\infty}{+}$ & $\stackrel{q}{q}$ & in & $\bar{n}$ & ก & $\tilde{n}$ & $\stackrel{\nabla}{n}$ & $n$ & 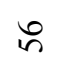 & $\hat{n}$ & $\stackrel{\infty}{n}$ & in & 8 & $\vec{\sigma}$ \\
\hline
\end{tabular}




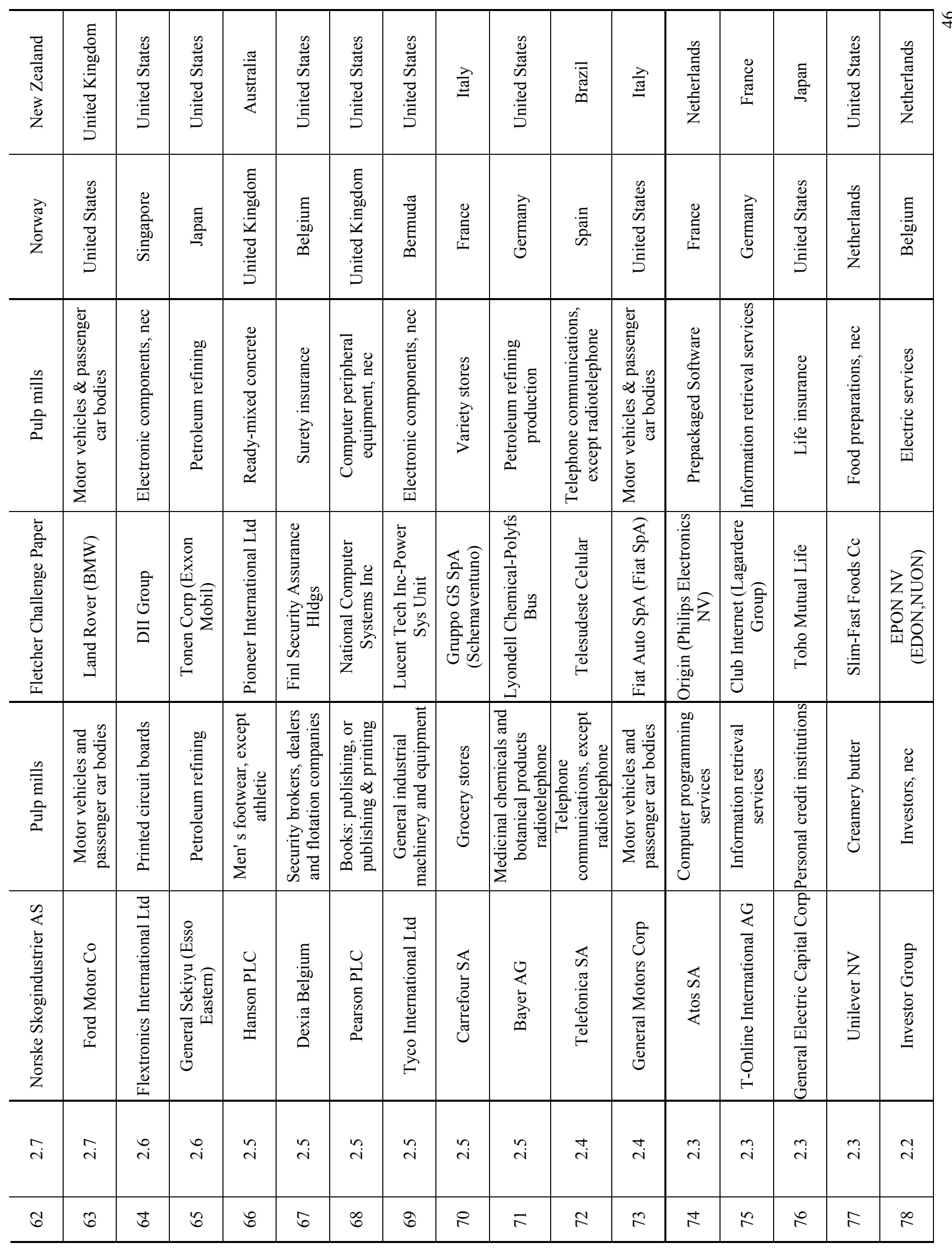




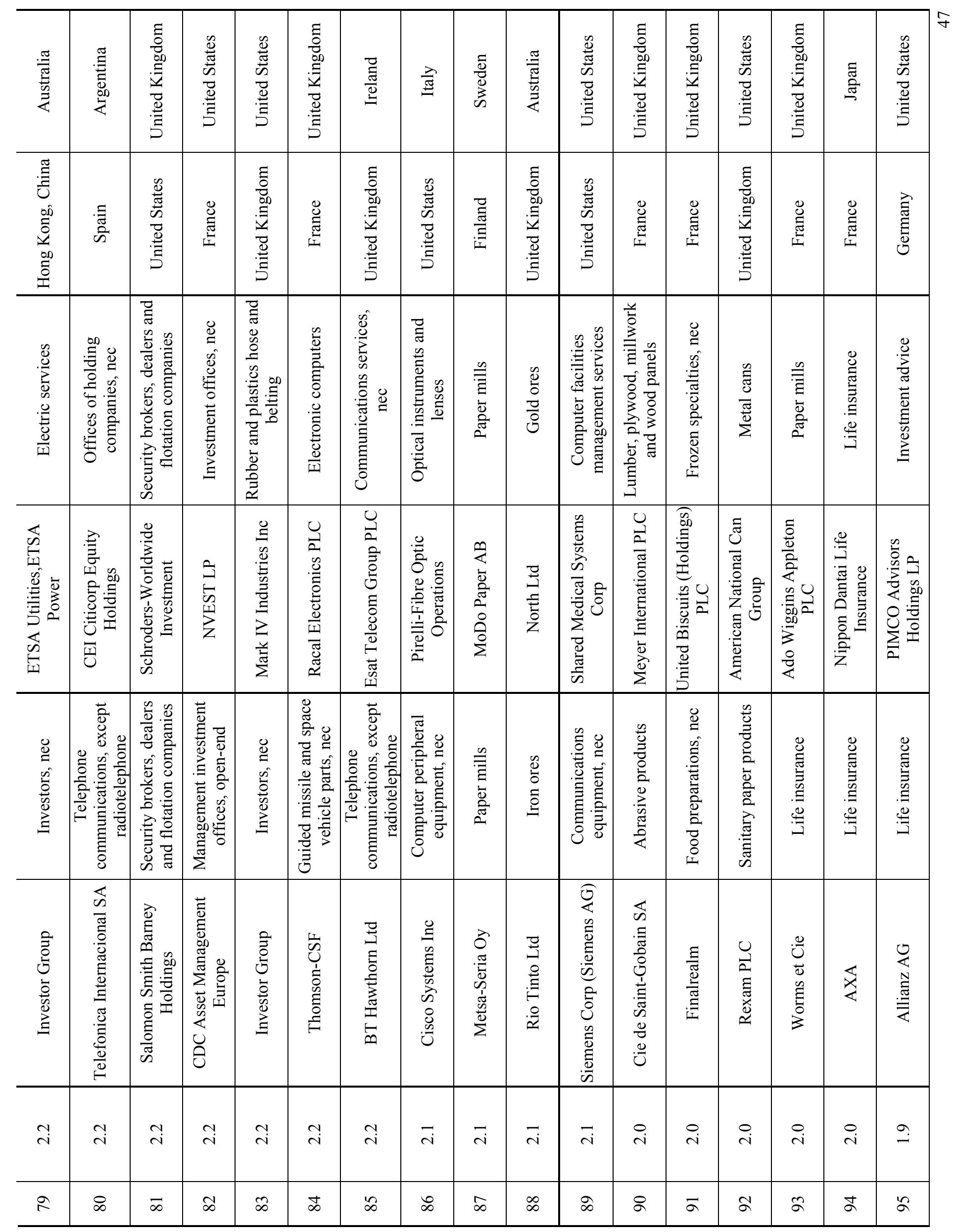




\begin{tabular}{|c|c|c|c|c|c|c|c|c|c|c|c|c|c|c|c|}
\hline $\begin{array}{l}\text { స్ } \\
\text { 心్త్ర }\end{array}$ & 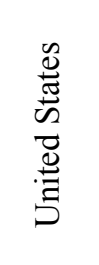 & 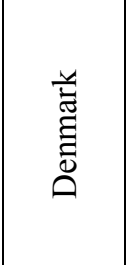 & 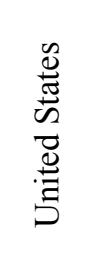 & 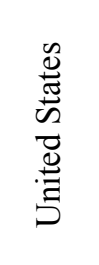 & 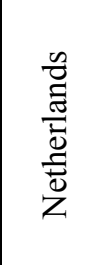 & 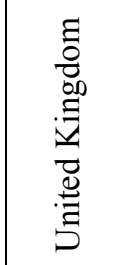 & 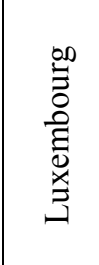 & 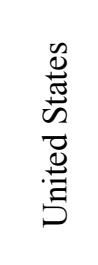 & 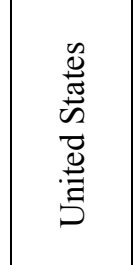 & 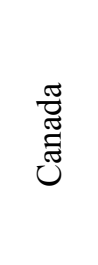 & 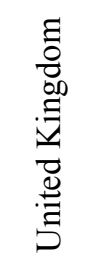 & 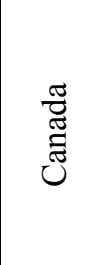 & 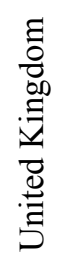 & 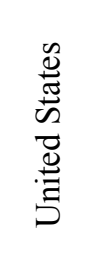 & 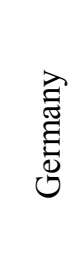 \\
\hline 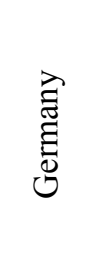 & 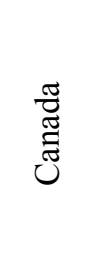 & $\begin{array}{l}\overrightarrow{7} \\
\text { ᄅे } \\
\text { z }\end{array}$ & 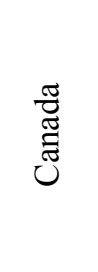 & 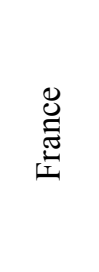 & 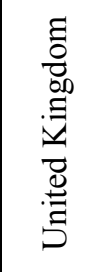 & 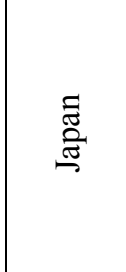 & 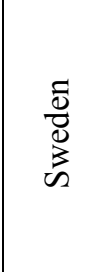 & 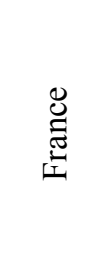 & 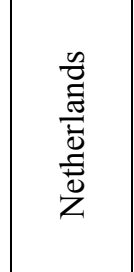 & 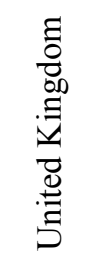 & 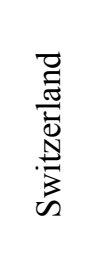 & 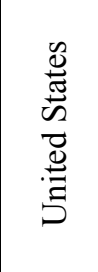 & 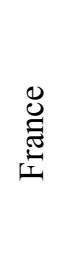 & 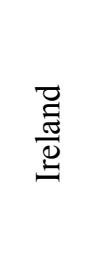 & 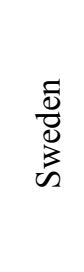 \\
\hline 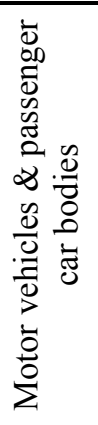 & 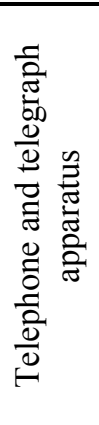 & 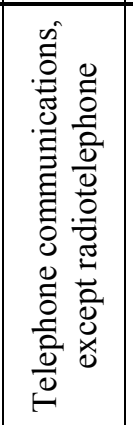 & 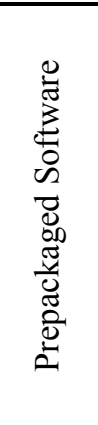 & 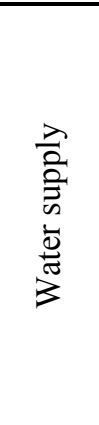 & 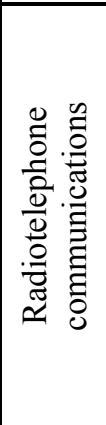 & 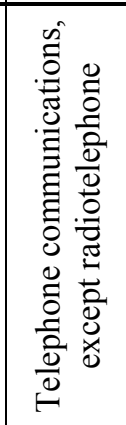 & 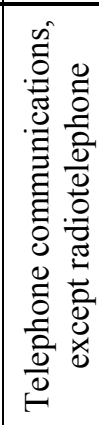 & 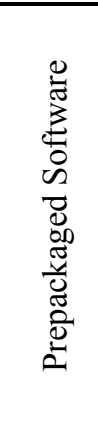 & 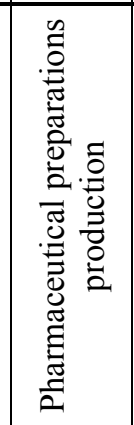 & 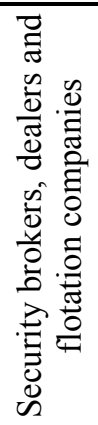 & 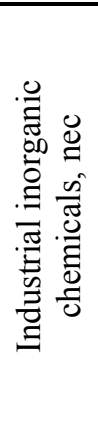 & 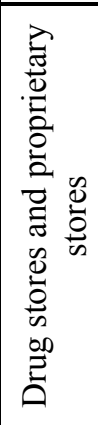 & 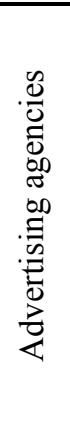 & 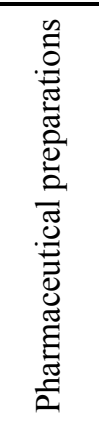 & 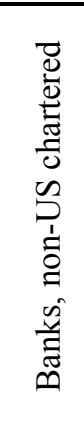 \\
\hline 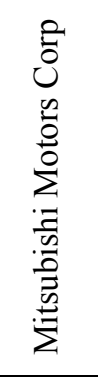 & 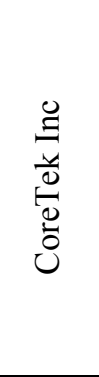 & $\begin{array}{l}\tilde{0} \\
\stackrel{0}{0} \\
\stackrel{0}{0} \\
\mathscr{n}\end{array}$ & 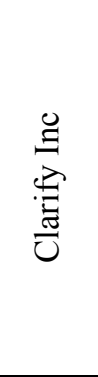 & 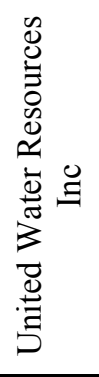 & 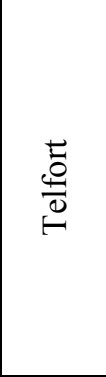 & 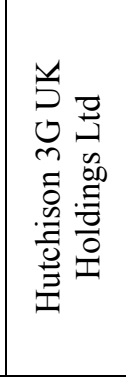 & 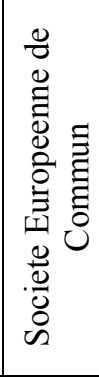 & 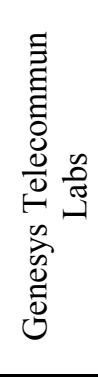 & 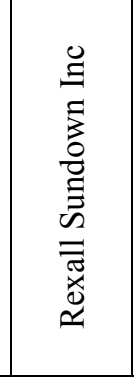 & 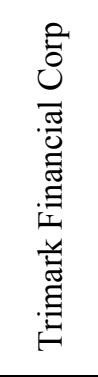 & 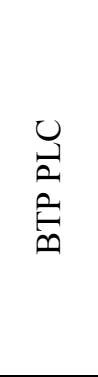 & 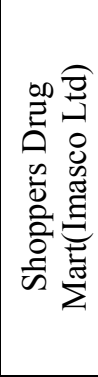 & 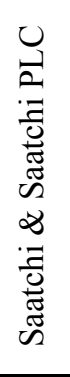 & 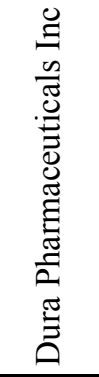 & 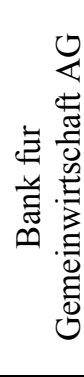 \\
\hline 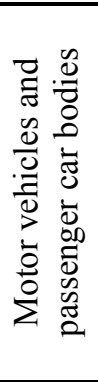 & 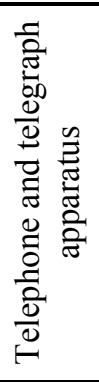 & 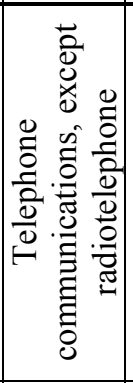 & 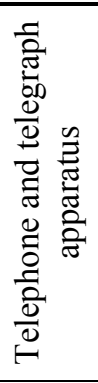 & 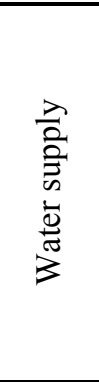 & 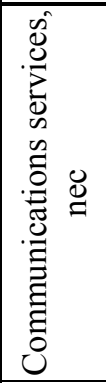 & 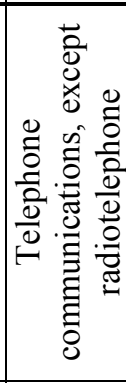 & 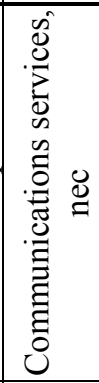 & 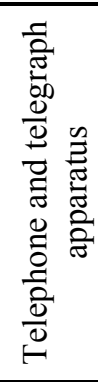 & 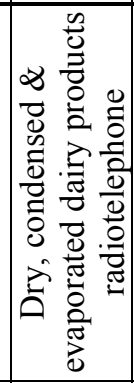 & 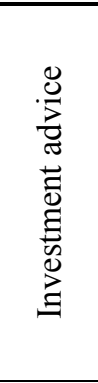 & 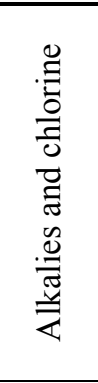 & 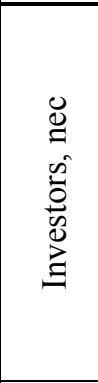 & 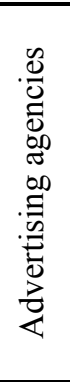 & 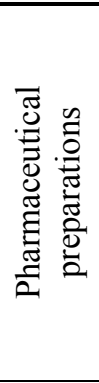 & 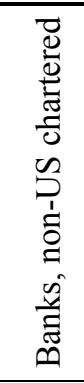 \\
\hline 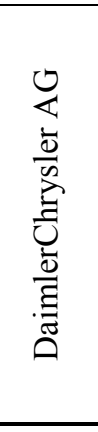 & 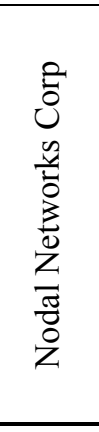 & 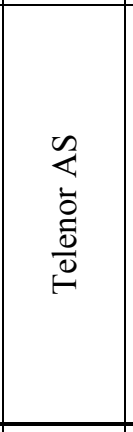 & 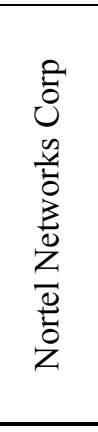 & 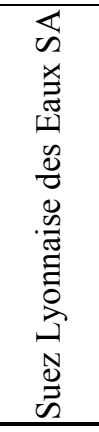 & 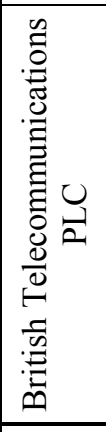 & $\begin{array}{l}0 \\
\Xi \\
0 \\
0 \\
0 \\
0 \\
0 \\
! \\
\vdots\end{array}$ & 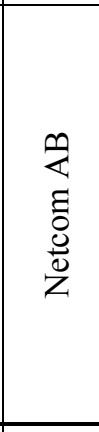 & 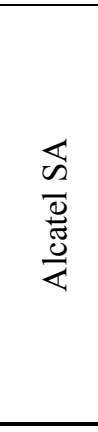 & 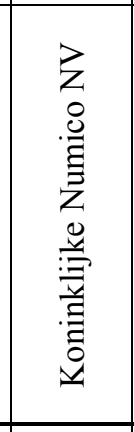 & 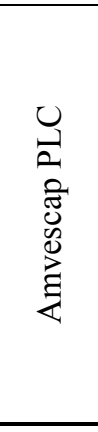 & 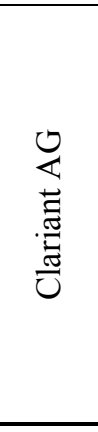 & 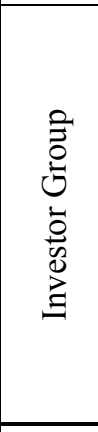 & 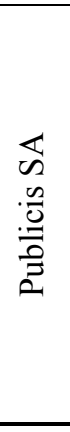 & 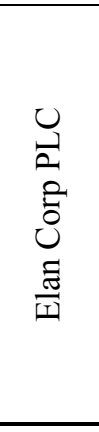 & 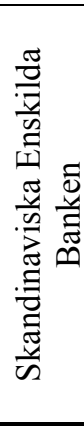 \\
\hline$\stackrel{9}{-}$ & 9 & $\stackrel{9}{-}$ & 9 & $\stackrel{\infty}{-}$ & $\stackrel{\infty}{\infty}$ & $\stackrel{\infty}{-}$ & $\stackrel{\infty}{\longrightarrow}$ & $\stackrel{\infty}{-}$ & $\stackrel{\infty}{-}$ & $\stackrel{\infty}{-}$ & I & $\cong$ & $\cong$ & 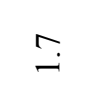 & 今 \\
\hline ட & $\hat{a}$ & $\stackrel{\infty}{a}$ & à & 8 & 으 & ఠิ & $\hat{\varrho}$ & $\underset{\Xi}{ \pm}$ & $\stackrel{2}{\varrho}$ & 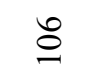 & $\hat{0}$ & $\stackrel{\infty}{\circ}$ & $\stackrel{8}{0}$ & $\stackrel{ }{=}$ & $\Xi$ \\
\hline
\end{tabular}




\begin{tabular}{|c|c|c|c|c|c|c|c|c|c|c|c|c|c|c|c|}
\hline 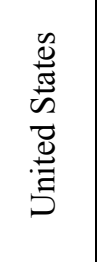 & $\begin{array}{l}\frac{\pi}{0} \\
\vec{N} \\
0 \\
\stackrel{0}{0}\end{array}$ & 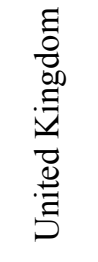 & 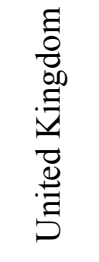 & 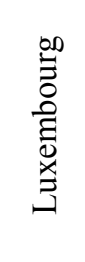 & 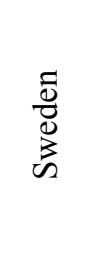 & 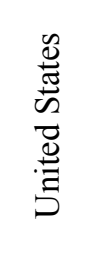 & 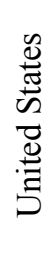 & 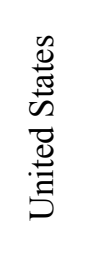 & $\begin{array}{l}\overline{\widetilde{J}} \\
\stackrel{0}{0} \\
\stackrel{0}{0} \\
0\end{array}$ & 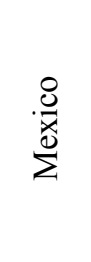 & 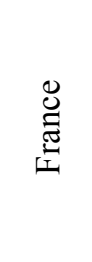 & 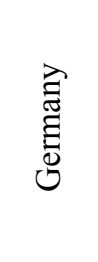 & 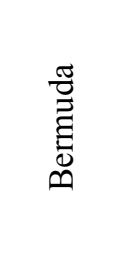 & 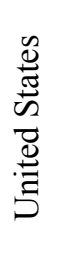 & 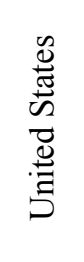 \\
\hline 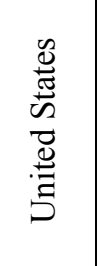 & 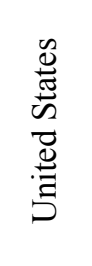 & 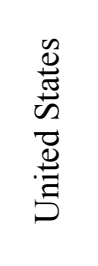 & 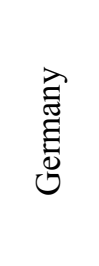 & 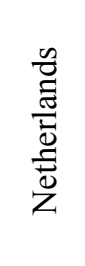 & 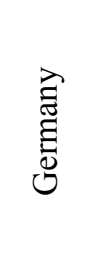 & 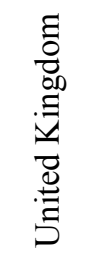 & 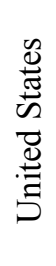 & 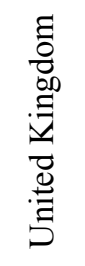 & $\begin{array}{l}\text { : } \\
\text { के }\end{array}$ & $\begin{array}{l}\text { : } \\
\text { के }\end{array}$ & 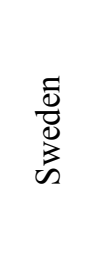 & 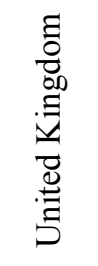 & 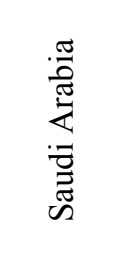 & 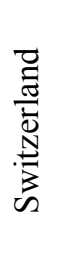 & 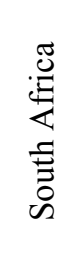 \\
\hline 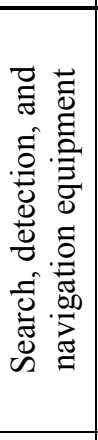 & 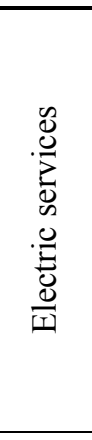 & 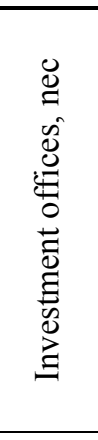 & 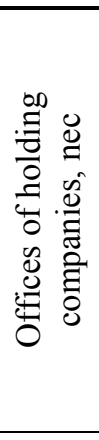 & 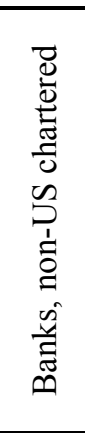 & 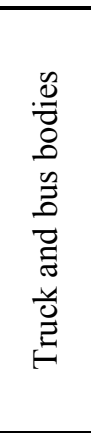 & 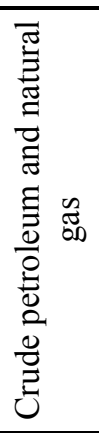 & 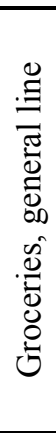 & 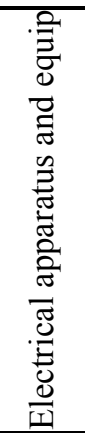 & 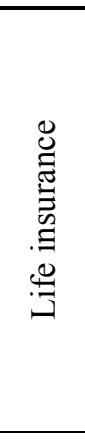 & 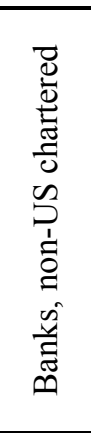 & 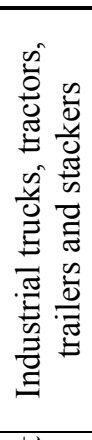 & 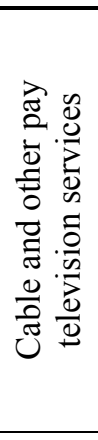 & 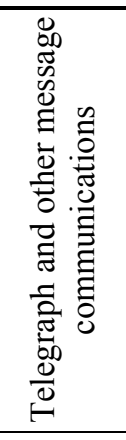 & 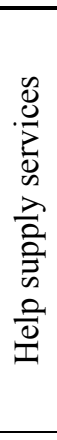 & 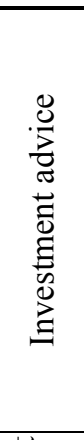 \\
\hline 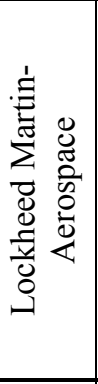 & 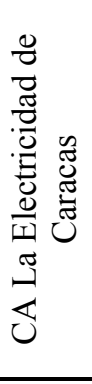 & 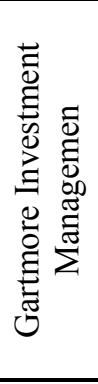 & 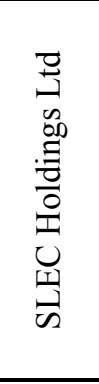 & 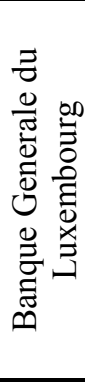 & 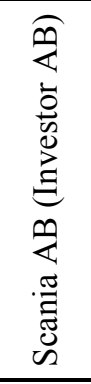 & 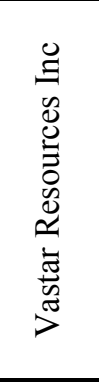 & 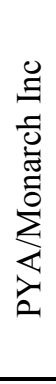 & 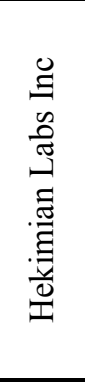 & 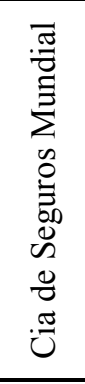 & 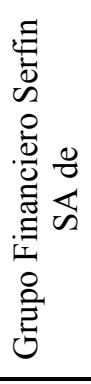 & 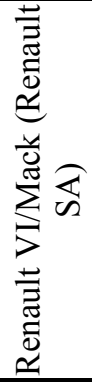 & 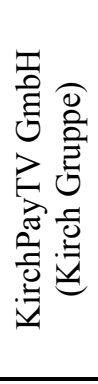 & 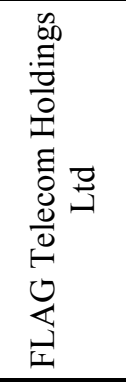 & 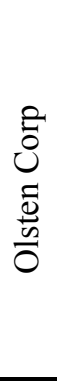 & 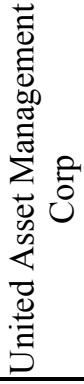 \\
\hline 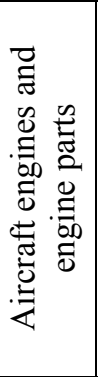 & 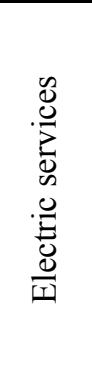 & 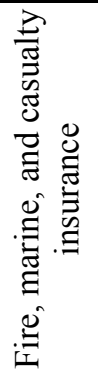 & 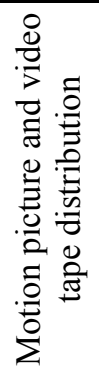 & 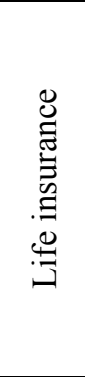 & 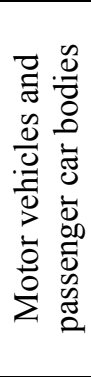 & 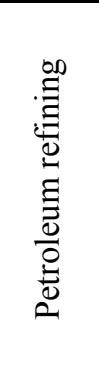 & 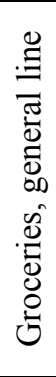 & 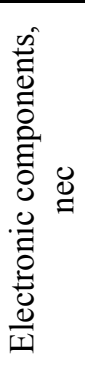 & 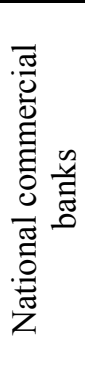 & 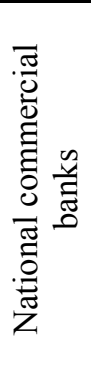 & 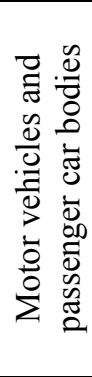 & 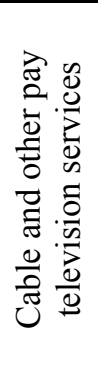 & 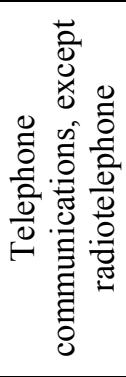 & 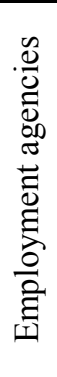 & 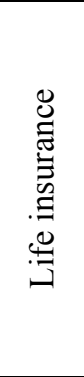 \\
\hline 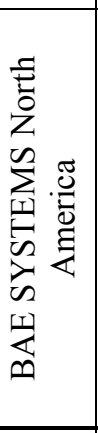 & 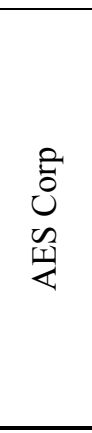 & 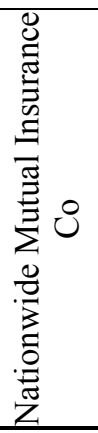 & 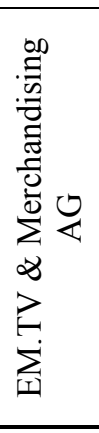 & $\begin{array}{l}z \\
z \\
o \\
Z \\
.0 \\
.0 \\
1\end{array}$ & 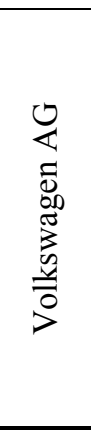 & 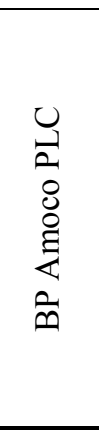 & $\begin{array}{l}0 \\
\Xi \\
8 \\
.0 \\
0 \\
0 \\
0 \\
0 \\
0 \\
0 \\
0 \\
0\end{array}$ & 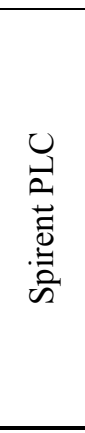 & 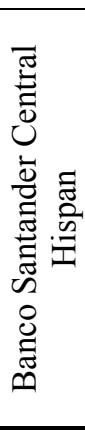 & 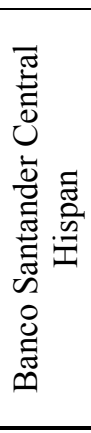 & $\begin{array}{l}m \\
\frac{1}{2} \\
0 \\
\frac{1}{0} \\
>\end{array}$ & 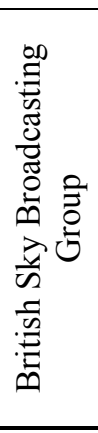 & 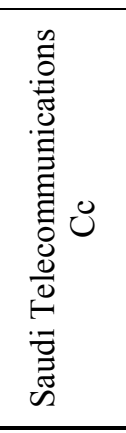 & 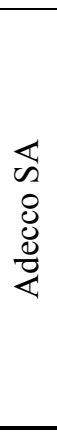 & 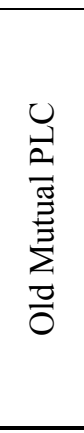 \\
\hline I & $\Xi$ & . & $\stackrel{\text { }}{\circ}$ & $\stackrel{\text { }}{\circ}$ & $\stackrel{0}{-}$ & $\stackrel{0}{-}$ & $\stackrel{\text { }}{ }$ & $\stackrel{\text { Pִ }}{ }$ & $\stackrel{0}{-}$ & $\because$ & $\stackrel{n}{\sim}$ & $\because$ & $\because$ & $\because$ & 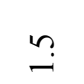 \\
\hline$\stackrel{\cong}{\Xi}$ & $\stackrel{\cong}{=}$ & $\Xi$ & $\stackrel{n}{=}$ & $\stackrel{0}{=}$ & 三 & $\stackrel{\infty}{=}$ & $\stackrel{9}{ }$ & 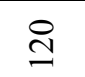 & $\vec{\beth}$ & ป & $\stackrel{\overbrace{}}{\beth}$ & $\stackrel{\Xi}{\beth}$ & $\tilde{\Xi}$ & $\stackrel{\circ}{\sim}$ & $\widehat{\cong}$ \\
\hline
\end{tabular}




\begin{tabular}{|c|c|c|c|c|c|c|c|c|c|c|c|c|c|c|c|c|}
\hline 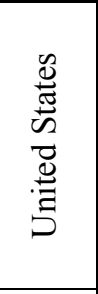 & 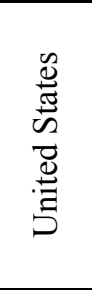 & 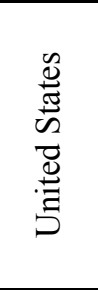 & 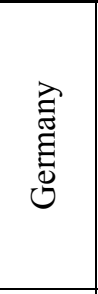 & 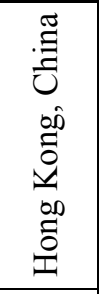 & 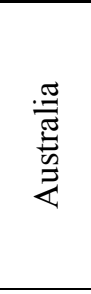 & 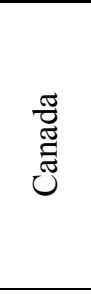 & 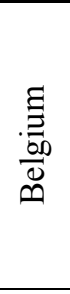 & 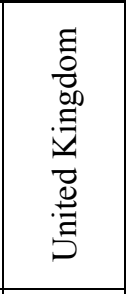 & 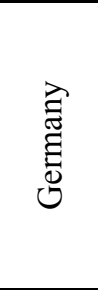 & 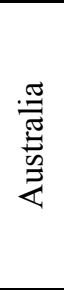 & 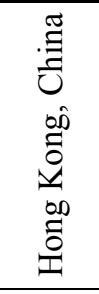 & $\begin{array}{l}\overrightarrow{\mathrm{T}} \\
\stackrel{3}{0} \\
\stackrel{2}{Z}\end{array}$ & 号 & 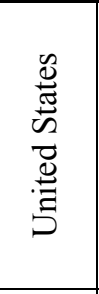 & $\begin{array}{l}\vec{E} \\
\frac{\sigma}{0} \\
2\end{array}$ & 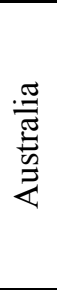 \\
\hline 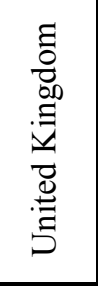 & 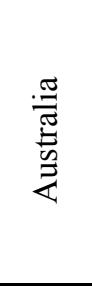 & 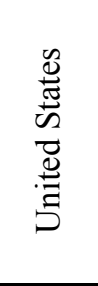 & 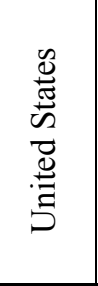 & 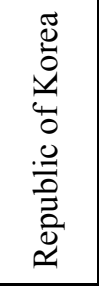 & 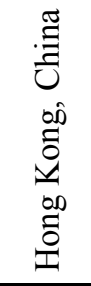 & 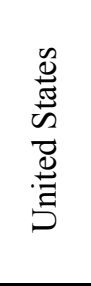 & 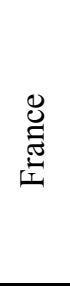 & 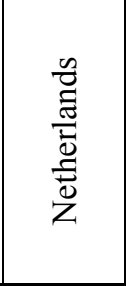 & 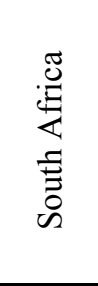 & 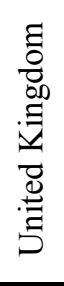 & 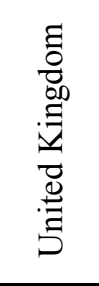 & 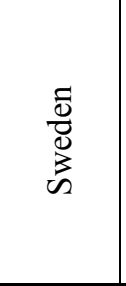 & 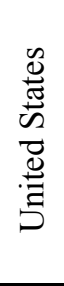 & 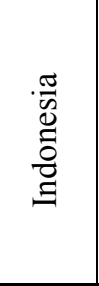 & $\begin{array}{l}\ddot{\Xi} \\
\stackrel{ \pm}{ \pm} \\
.\end{array}$ & 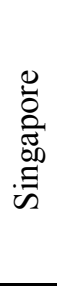 \\
\hline 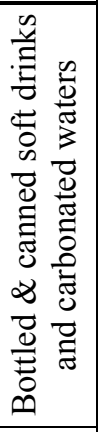 & 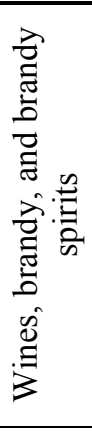 & 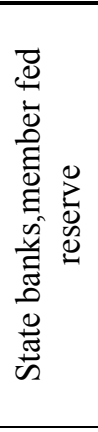 & 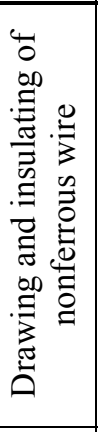 & 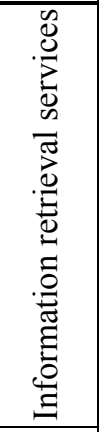 & 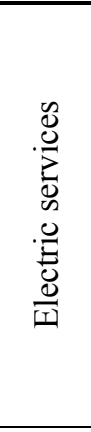 & 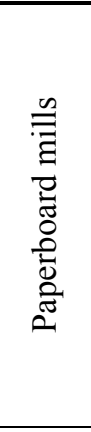 & 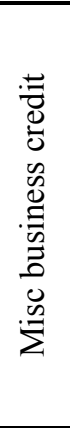 & 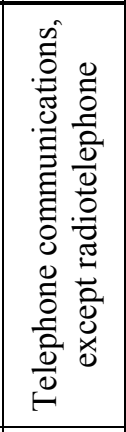 & 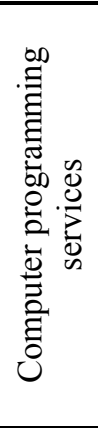 & 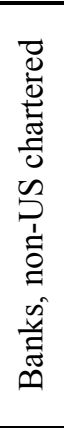 & 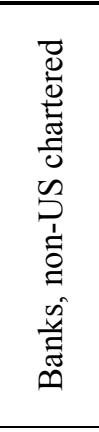 & 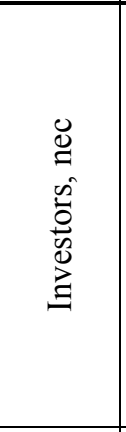 & 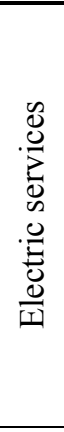 & 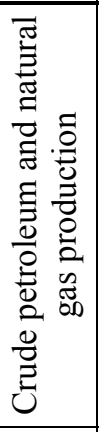 & 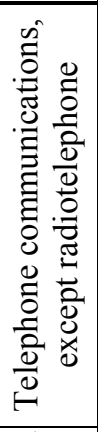 & 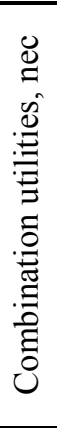 \\
\hline 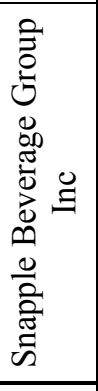 & 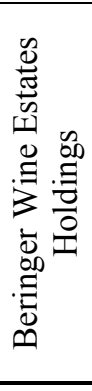 & 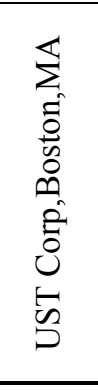 & 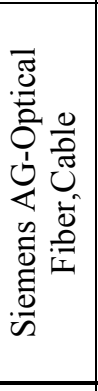 & 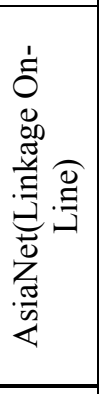 & 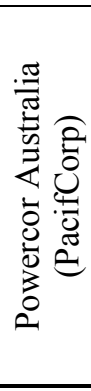 & 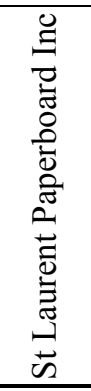 & $\begin{array}{l}\varangle \\
\text { D } \\
0 \\
0 \\
0 \\
0 \\
0 \\
\simeq \\
\Xi \\
0 \\
0 \\
0 \\
0 \\
0 \\
0\end{array}$ & 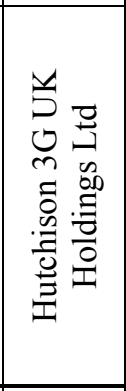 & 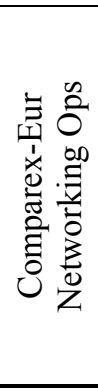 & 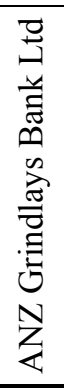 & 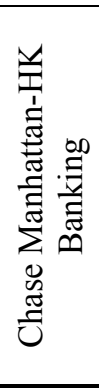 & 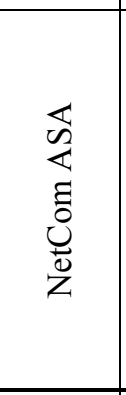 & 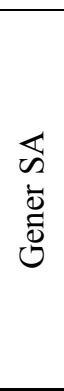 & 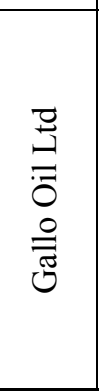 & 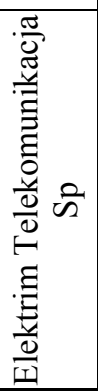 & 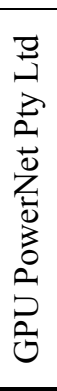 \\
\hline 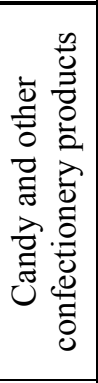 & 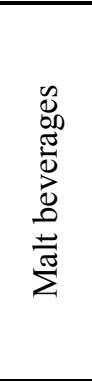 & 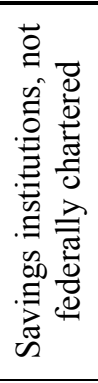 & 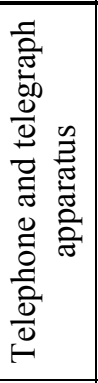 & 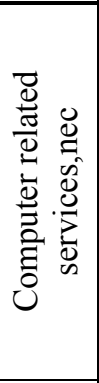 & 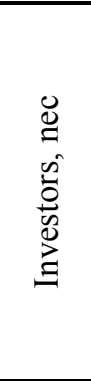 & 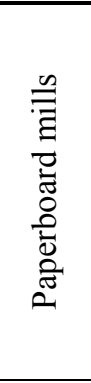 & 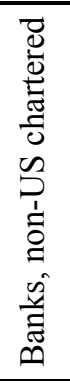 & 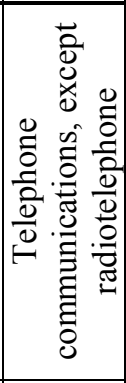 & 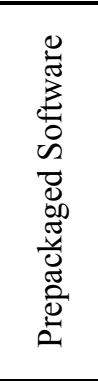 & 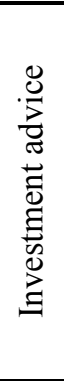 & 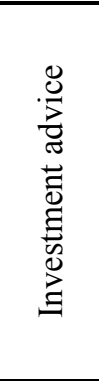 & 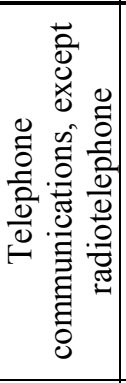 & 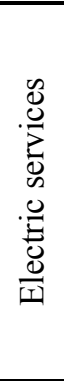 & 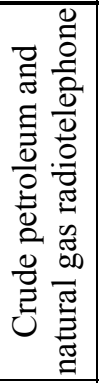 & 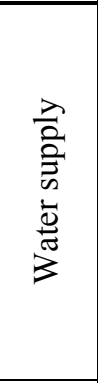 & 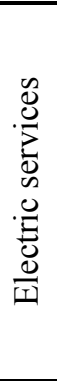 \\
\hline 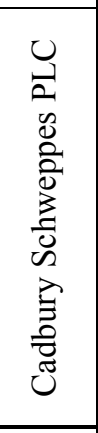 & 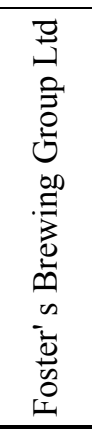 & 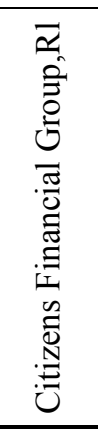 & $\begin{array}{l}\mathscr{\Xi} \\
\text { OD } \\
. \\
0 \\
0\end{array}$ & 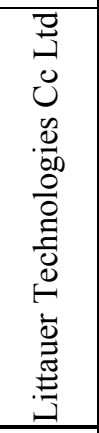 & 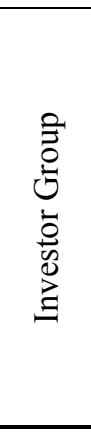 & 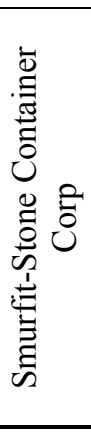 & 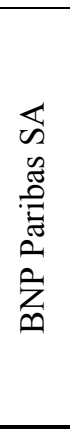 & 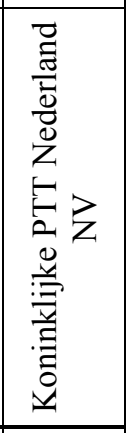 & 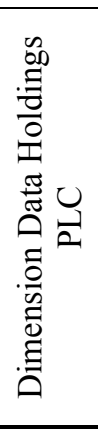 & 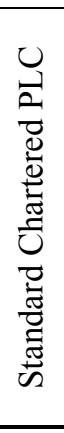 & 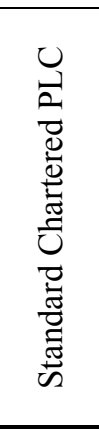 & 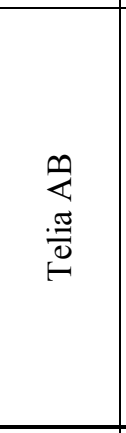 & 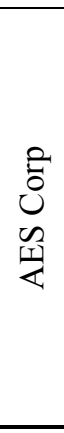 & 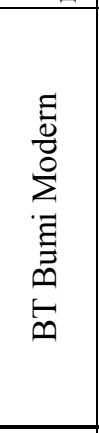 & 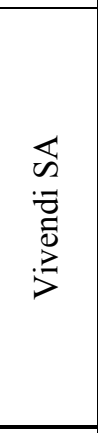 & 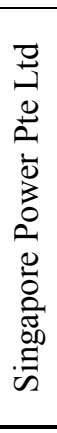 \\
\hline$\stackrel{n}{-}$ & $\stackrel{+}{-}$ & $\stackrel{+}{-}$ & $\stackrel{\nabla}{-}$ & $\stackrel{+}{-}$ & $\stackrel{\nabla}{\sim}$ & $\stackrel{+}{\sim}$ & $\stackrel{+}{-}$ & $\stackrel{+}{\sim}$ & $\stackrel{?}{-}$ & $\stackrel{m}{\longrightarrow}$ & $\stackrel{?}{-}$ & $\stackrel{m}{-}$ & $\dddot{m}$ & $\stackrel{?}{-}$ & $\stackrel{?}{-}$ & $\stackrel{?}{-}$ \\
\hline 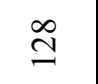 & తิ & 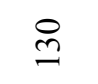 & $\vec{m}$ & 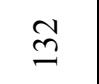 & $\stackrel{m}{n}$ & $\stackrel{\varpi}{\sim}$ & $\stackrel{n}{n}$ & $\stackrel{0}{\sim}$ & $\hat{n}$ & $\stackrel{\infty}{n}$ & ભે & $\stackrel{\text { 巳 }}{ \pm}$ & $\bar{\Xi}$ & I & $\stackrel{\mathscr{I}}{ \pm}$ & $\underset{J}{\exists}$ \\
\hline
\end{tabular}




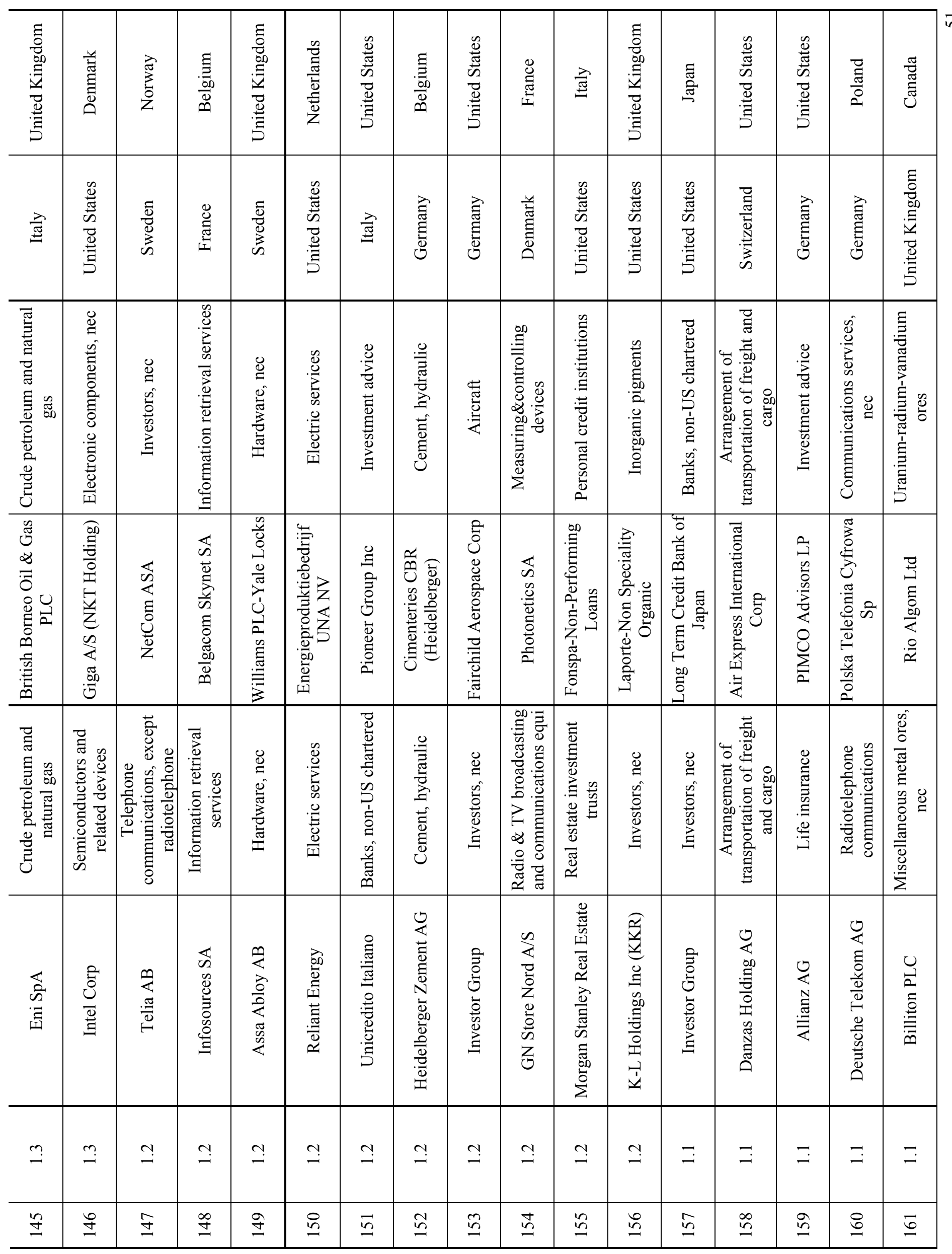




\begin{tabular}{|c|c|c|c|c|c|c|c|c|c|c|c|c|c|}
\hline 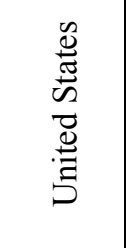 & 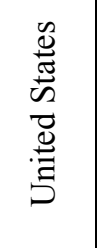 & 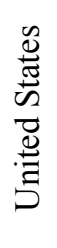 & 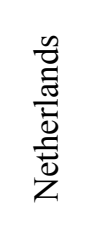 & $\begin{array}{l}\text { हี } \\
\text { की }\end{array}$ & 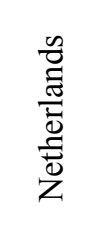 & 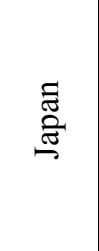 & 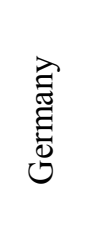 & 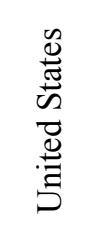 & 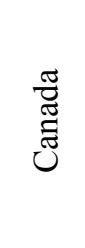 & 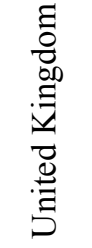 & $\begin{array}{l}\overline{\bar{N}} \\
\overline{\mathscr{D}} \\
\end{array}$ & 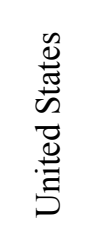 & $\begin{array}{l}\overline{\mathbb{N}} \\
\text { صृ }\end{array}$ \\
\hline 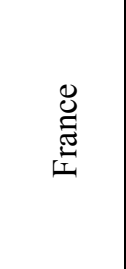 & 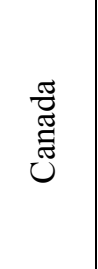 & 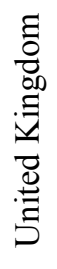 & 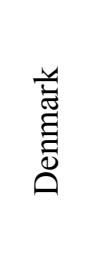 & 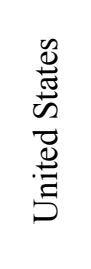 & 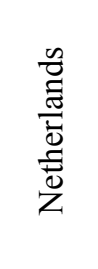 & 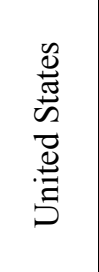 & $\stackrel{\vec{\Xi}}{\stackrel{\Xi}{E}}$ & 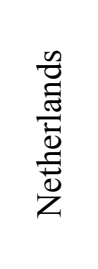 & 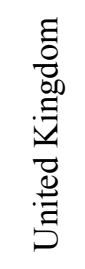 & 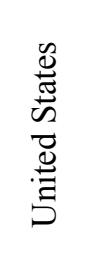 & $\begin{array}{l}\text { 颉 } \\
\text { की }\end{array}$ & $\begin{array}{l}\text { స్ } \\
\text { 心్心 }\end{array}$ & $\begin{array}{l}\text { : } \\
\text { के }\end{array}$ \\
\hline 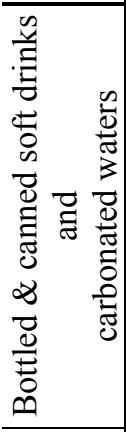 & 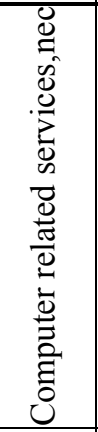 & 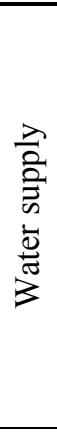 & 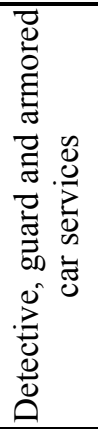 & 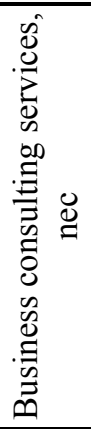 & 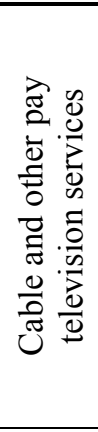 & 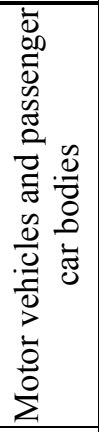 & 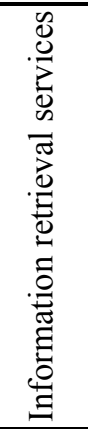 & 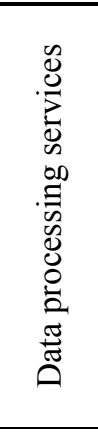 & 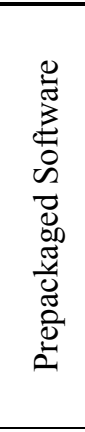 & 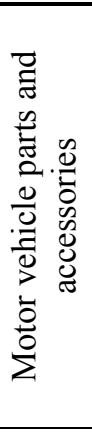 & 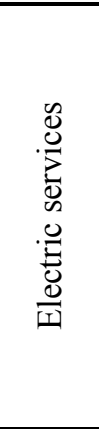 & 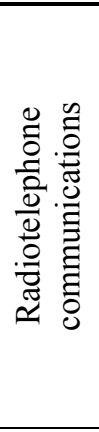 & 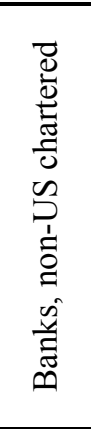 \\
\hline 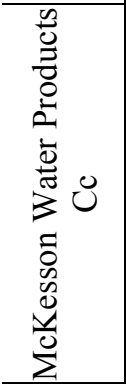 & 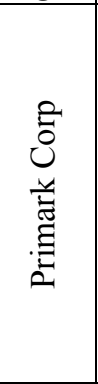 & 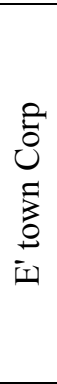 & 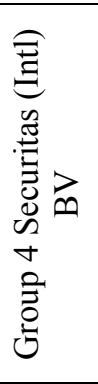 & 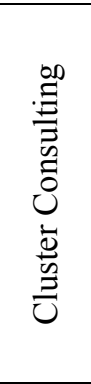 & 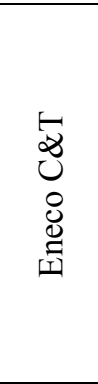 & 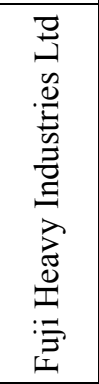 & 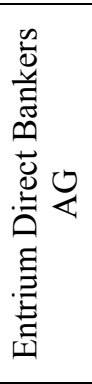 & 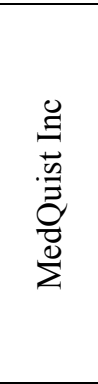 & 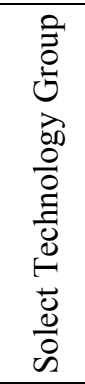 & 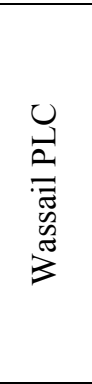 & 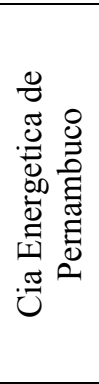 & 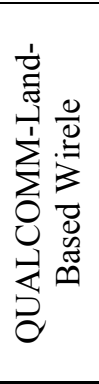 & 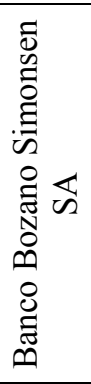 \\
\hline 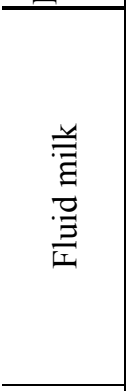 & 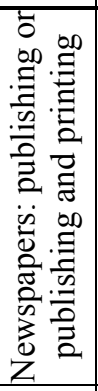 & 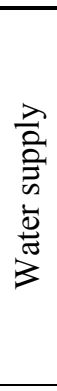 & 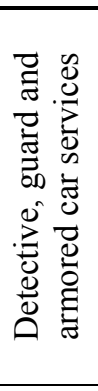 & 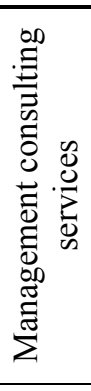 & 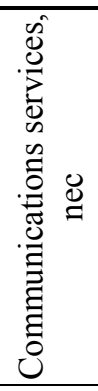 & 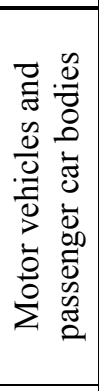 & 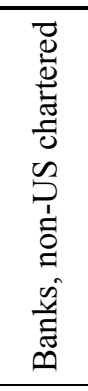 & 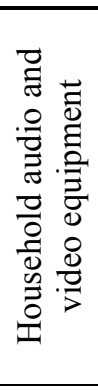 & 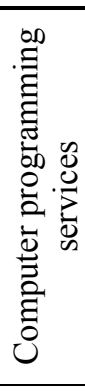 & 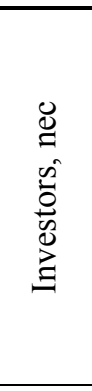 & 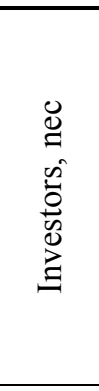 & 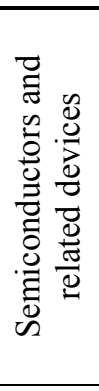 & 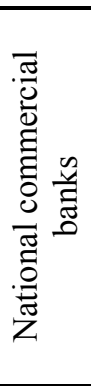 \\
\hline $\begin{array}{l}\tilde{\Xi} \\
0 \\
0 \\
0 \\
\tilde{\Xi} \\
\bar{\Xi} \\
0\end{array}$ & 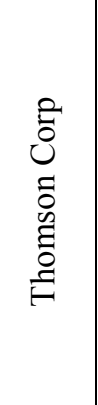 & 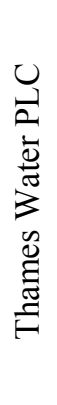 & 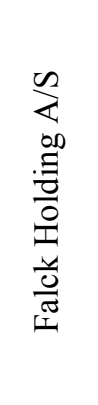 & 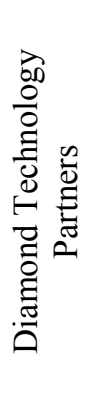 & 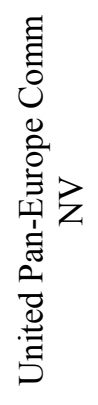 & 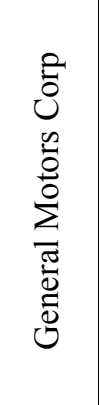 & 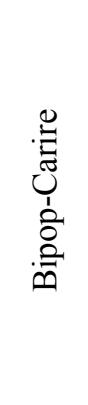 & 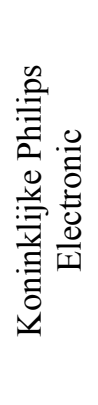 & 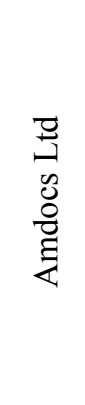 & 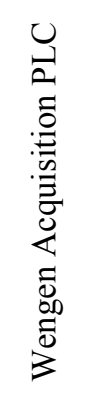 & 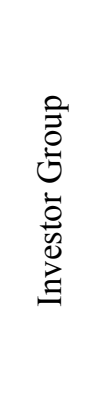 & 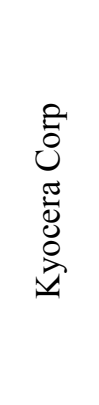 & 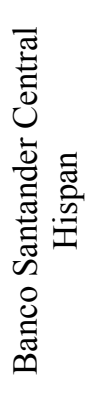 \\
\hline 二 & 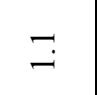 & $\exists$ & $\exists$ & 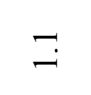 & $\exists$ & $\exists$ & $\exists$ & $\stackrel{\circ}{-}$ & $\stackrel{\circ}{-}$ & $\stackrel{\circ}{-}$ & $\stackrel{\circ}{-}$ & $\stackrel{\circ}{-}$ & $\stackrel{\circ}{-}$ \\
\hline$\widetilde{\sigma}$ & 8 & $\underset{U}{\mathbb{V}}$ & 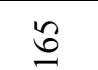 & 8 & $\tilde{\sigma}$ & $\underset{0}{\infty}$ & oे & 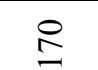 & $\Xi$ & $\cong$ & $\cong$ & $\underset{I}{ \pm}$ & $\stackrel{n}{I}$ \\
\hline
\end{tabular}


Appendix Table 2: Major regulatory changes affecting the banking sectors of the 13 OECD nations considered in this paper.

\begin{tabular}{|c|c|c|}
\hline OECD nation & Year & Short description of regulatory change \\
\hline United States & 1994 & Implementation of the Reigle Neal Interstate Act \\
\hline United States & 1999 & Implementation of the Gramm-Leach-Billey Act \\
\hline Canada & 1992 & Phasing out of banking reserve requirements \\
\hline Canada & 1999 & $\begin{array}{l}\text { Relaxation of rules allowing establishment of foreign } \\
\text { banks }\end{array}$ \\
\hline Australia & 1992 & $\begin{array}{l}\text { Relaxation of rules allowing establishment of foreign } \\
\text { banks }\end{array}$ \\
\hline Australia & 1997 & End of the so-called Six Pillars policy \\
\hline France & 1993 & Privatization of some banks \\
\hline France & 1995 & Implementation of a deposit insurance directive \\
\hline Germany & 1992 & Implementation of second European Banking Directive \\
\hline Italy & 1993 & Implementation of second European Banking Directive \\
\hline Italy & 1994 & Privatization of some banks \\
\hline $\begin{array}{l}\text { United } \\
\text { Kingdom }\end{array}$ & 1998 & $\begin{array}{l}\text { Financial Services Authority takes on some bank } \\
\text { regulatory powers }\end{array}$ \\
\hline
\end{tabular}

Source: Annex II.3, BIS (2001).

Note: This table is not supposed to summarize all of the regulatory changes in the 13 OECD nations during the years 1990 to 1999. Rather, using BIS (2001), it identifies that major regulatory changes that affected a nation's banking sector during the years that it was in the unbalanced panel. Therefore, if a nation was in the unbalanced panel from 1990 to 1993, changes in the regulatory regime for banks after 1993 would not be reported. 